Instituto de Psicologia da Universidade de São Paulo

Mestrado em Psicologia Clínica

Camila Machado de Oliveira

Encontros e Desencontros: considerações sobre o lugar da família na clínica do Acompanhamento Terapêutico

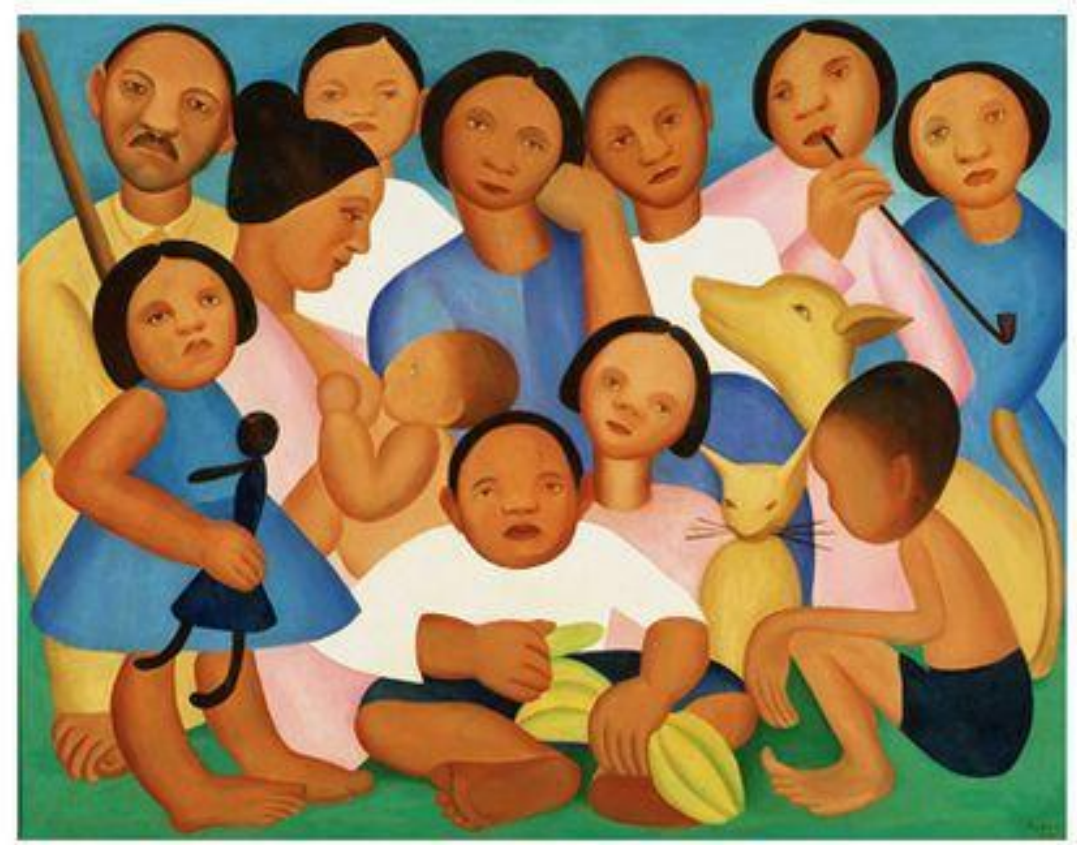

São Paulo

2018 
Camila Machado de Oliveira

Encontros e Desencontros: considerações sobre o lugar da família na clínica do Acompanhamento Terapêutico

\section{Versão Corrigida}

Dissertação apresentada ao Instituto de Psicologia da Universidade de São Paulo como parte dos requisitos para a obtenção do título de Mestre em Psicologia Clínica.

Área de concentração: Psicologia Clínica

Orientador: Professor Dr. Gilberto Safra

São Paulo

2018 
AUTORIZO A REPRODUÇÃO E DIVULGAÇÃO TOTAL OU PARCIAL DESTE TRABALHO, POR QUALQUER MEIO CONVENCIONAL OU ELETRÔNICO, PARA FINS DE ESTUDO E PESQUISA, DESDE QUE CITADA A FONTE.

Catalogação na publicação Biblioteca Dante Moreira Leite

Instituto de Psicologia da Universidade de São Paulo Dados fornecidos pelo(a) autor(a)

Oliveira, Camila Machado

Encontros e Desencontros: considerações sobre o lugar da família na clínica do Acompanhamento Terapêutico / Camila Machado Oliveira; orientador Gilberto Safra. -- São Paulo, 2018.

$139 \mathrm{f}$.

Dissertação (Mestrado - Programa de Pós-Graduação em Psicologia Clínica) -Instituto de Psicologia, Universidade de São Paulo, 2018.

1. Acompanhamento Terapêutico. 2. Família. 3. Ética. 4. Winnicott. 5. Safra. I. Safra, Gilberto, orient. II. Título. 
Nome: Oliveira, Camila Machado

Título: Encontros e Desencontros: considerações sobre o lugar da família na clínica do Acompanhamento Terapêutico

Dissertação apresentada ao Programa de PósGraduação em Psicologia Clínica do Instituto de Psicologia da Universidade de São Paulo para Obtenção do titulo de Mestre em Psicologia Cínica

Aprovada em 1

Banca examinadora

Prof. Dr.(a)

Instituição:

Assinatura:

Prof. Dr.(a)

Instituição:

Assinatura:

Prof. Dr.(a)

Instituição:

Assinatura:

Prof. Dr.(a)

Instituição:

Assinatura: 

À minha avó (in memoriam), aos meus pais, ao Anderson, à Maria, ao Gilberto... 
Não me iludo

Tudo permanecerá do jeito que tem sido

Transcorrendo

Transformando

Tempo e espaço navegando todos os sentidos

Pães de Açúcar

Corcovados

Fustigados pela chuva e pelo eterno vento

Água mole

Pedra dura

Tanto bate que não restará nem pensamento

Tempo rei, ó, tempo rei, ó, tempo rei

Transformai as velhas formas do viver

Ensinai-me, ó, pai, o que eu ainda não sei

Mãe Senhora do Perpétuo, socorrei

Pensamento

Mesmo o fundamento singular do ser humano

De um momento

Para o outro

Poderá não mais fundar nem gregos nem baianos

Mães zelosas

Pais corujas

Vejam como as águas de repente ficam sujas

Não se iludam

Não me iludo

Tudo agora mesmo pode estar por um segundo

Tempo rei, ó, tempo rei, ó, tempo rei

Transformai as velhas formas do viver

Ensinai-me, ó, pai, o que eu ainda não sei

Mãe Senhora do Perpétuo, socorrei 


\section{AGRADECIMENTOS}

Dedico essa dissertação a todas as famílias e pacientes que fizeram parte desta minha trajetória, pela confiança depositada em meu trabalho e pela possibilidade que me ofertaram de refletir sobre esse tema. Essa pesquisa é a extensão de um trabalho que foi iniciado lá atrás, presença e memória, registro em sua forma mais viva: encontros e desencontros. Assim é a vida!

Ao querido e especial orientador, Gilberto Safra! Pessoa sensível e competente: enquanto faz, sente, e enquanto sente, faz. Acompanhante que acolhe, silencia, aproxima-se, retira-se, enxerga entre e além. Antes de mais nada agradeço pela obra, a qual possibilitou que o mais antigo e profundo em mim encontrasse diálogo. Obrigada também por atravessar, durante esse percurso acadêmico, simplicidades e lonjuras comigo. Que bálsamo encontrar pessoas como você na universidade...

Ao meu marido, Anderson! Amor que atravessa a eternidade. Obrigada pela existência, pelas tentativas de compreensão e por ser luz! De tempos em tempos revezamos, ora eu, ora você. Assim nos fortalecemos, assim caminhamos. Estou de volta, o nosso lar nos espera.

À minha querida e amada avó, pelo aconchego e por todo o amor! Ensinou-me a pular janelas quando as portas estavam trancadas, me fez arteira e decidida. Aos meus pais, Márcia e Antônio, que me ensinaram algo precioso: sentir o sol em mim, mesmo quando lá fora ainda era tempestade. A ela pelo canto da Elis Regina, a ele, pelo banho de rio. Ao meu irmão, pelas memórias de infância. Aos meus sogros pelos domingos e aos meus sobrinhos por todo o carinho, brincadeiras e risadas.

À família Caleffi Ferraz, que me acolheu em sua casa ofertando amor, compartilhando o pão, distribuindo luz, minha segunda família. À Silvana Miranda, amiga querida de risadas soltas, obrigada pelo olhar sempre carinhoso, pela sensibilidade, pela transmissão de pensamento. À Aninha, amizade daquelas boas que se fizeram no cotidiano, amiga das coisas mais simples e, portanto, das mais 
preciosas, obrigada pelo sorriso, pelas palavras sinceras e pelo olhar sempre atento. Ao Leandro, amigo de risadas, confusões e incertezas. À Thábata e Marcella pelas reuniões sempre regadas de afeto, risadas e comidinhas. Ao Tiago, que através das conversas e risadas tornou esse percurso mais leve. À Liza, amiga e professora de espanhol, pelos bordados sempre cheios de delicadeza.

Às queridas Raquel Spaziani e Cleide, analistas especiais, pessoas pelas quais nutro grande carinho e gratidão. À Carmen Mion, minha mais nova analista. À Odete Coster, por compartilhar comigo a sua sensibilidade e por serenar as minhas angústias. À Michele Faria, pelo encontro recente e fecundo.

Ao Fernando Genaro, pelo rigor e pela verdade, do início ao fim. À querida Daniella Della Torre, pelo acolhimento em minha chegada ao AT e pela leitura do primeiro projeto. Ao Ricardo Telles de Deus, pela confiança depositada em meu trabalho e por possibilitar o meu primeiro contato com essa prática clínica. À Luciana Goldman, professora que me apresentou o AT ainda na faculdade e que leu os meus primeiros rabiscos. À Marília Milan, pelo olhar sempre atento e sensível.

Ao especial Kleber Barretto, nosso "Caetano Veloso" do AT! O seu "oxente" contagia sempre, contagia todos nós, contagia o campo do Acompanhamento Terapêutico. Obrigada por ter ensinado de maneira despretensiosa o que verdadeiramente importa. Obrigada por autorizar que a graça e o riso estejam sempre presentes nos atendimentos, na vida!

À Luciana Chauí por ter aberto as portas da AAT, lugar que me possibilitou tantos encontros. Ao Andrés Antúnez, pela leitura do projeto inicial, pelas contribuições e pelo acolhimento de sempre. À Margarida Mamede pelas contribuições na ocasião da defesa e pela forma cuidadosa que as teceu. À Maria Laura Frank, pela generosidade. À Dra. Vivian Wiplif pela confiança em meu trabalho e por possibilitar que eu adentre o universo do AT no judiciário. Pela aposta contagiante e pelo investimento sempre cuidadoso nessa clínica. 
À Claudia e Camila, secretárias do Departamento de Psicologia Clínica, pela seriedade e disponibilidade. À Agatha da recepção, pelo sorriso. Aos professores do Departamento de Psicologia Social do Instituto de Psicologia da USP, Luis Galeão, Alessandro Santos e Gustavo Massola. Ao primo Marcelo Cerrucci pela primeira tradução! Ao Eduardo Gentile, tradutor excepcional. À Betina Ruiz, pela paciência e revisão cuidadosa.

À Coordenação de Aperfeiçoamento de Pessoal de Nível Superior - CAPES, pelo auxílio financeiro! 
Só que a Ciência se equivoca no problema da natureza humana, e tende a perder de vista o ser humano como um todo.

Donald W. Winnicott. 
OLIVEIRA, C. M. Encontros e Desencontros: considerações sobre o lugar da família na clínica do Acompanhamento Terapêutico. 2018. Dissertação de Mestrado - Instituto de Psicologia, Universidade de São Paulo, São Paulo, 2018.

\section{RESUMO}

A presente pesquisa busca apresentar considerações sobre as diferentes formas de participação da família na clínica do Acompanhamento Terapêutico (AT). São as peculiaridades desse setting que tornam necessárias as reflexões sobre a família nesta modalidade clínica. A natureza da relação que se configura entre acompanhante-acompanhado é de extrema intimidade, viabilizada pelo número maior de horas, assim como pelo acompanhamento que ocorre no cotidiano do paciente. Tais especificidades trazem em seu bojo a presença familiar enquanto tema a ser considerado. Observam-se quatro formas de presença familiar neste enquadre de atendimento, a saber: 1) no próprio contato com a família, nos atendimentos realizados em consultório; 2) na presença dos familiares durante os acompanhamentos, quando realizados em ambiente domiciliar e extra-domiciliar; 3) na fala do paciente sobre a própria família, e por fim; 4) nas questões apresentadas pelos pacientes durante os atendimentos. Procura-se, através de narrativas literárias sintéticas de casos clínicos, considerar aspectos da relação "at-família" / "famíliaacompanhado" na clínica do Acompanhamento Terapêutico. A metodologia qualitativa-abdutiva é orientada pelo pensamento clínico de Donald. W. Winnicott, pediatra e psicanalista inglês, e do professor Dr. Gilberto Safra, psicanalista e pesquisador do Instituto de Psicologia da Universidade de São Paulo.

Palavras-Chave: acompanhamento terapêutico, família, ética, Winnicott, Safra. 
OLIVEIRA, C. M. Convergences and Divergences: Considerations about the Role of the Family during Therapeutic Follow-Up. 2018. Master's thesis - Institute of Psychology, University of São Paulo, São Paulo, 2018.

\begin{abstract}
The present study discusses considerations about the different forms of family participation during therapeutic follow-up. The peculiarities of this setting make it necessary to reflect on the family in this clinical modality. The nature of the relationship established between companions and those being accompanied is extremely intimate and made possible by the greater number of hours, as well as by the accompaniment that occurs in the daily life of the patients. Such specificities represent the presence of the family as an issue to be taken into consideration. There are four forms of family presence within this context, namely: (1) the contact with the family during the consultations at the doctor's office; (2) the presence of family members during followups performed at home or out-of-home settings; (3) patients' statements about their families; and (4) the questions raised by the patients during medical visits. Synthetic literature narratives of clinical cases were assessed to consider aspects of the relationships "therapist-family" and "family-patient" during therapeutic follow-up. The methodology abductive-qualitative was based on Donald W. Winnicott's clinical thinking, an English pediatrician and psychoanalyst, and Dr. Gilberto Safra, psychoanalyst and researcher at the Department of Clinical Psychology of the University of São Paulo, USP.
\end{abstract}

Keywords: therapeutic follow-up, family, ethics, Winnicott, Safra. 


\section{SUMÁRIO}

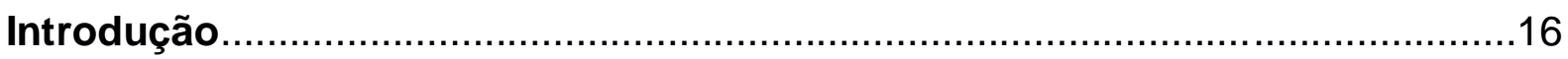

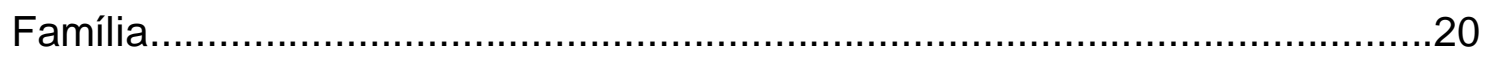

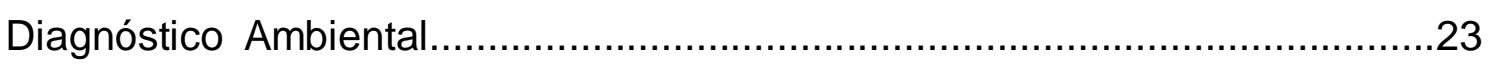

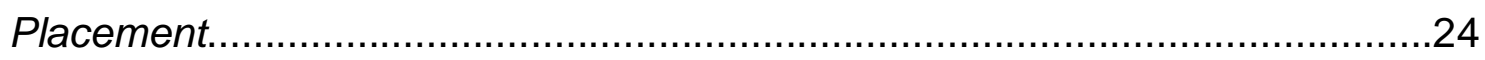

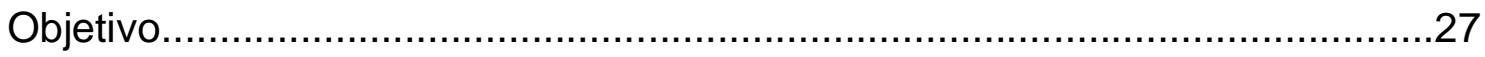

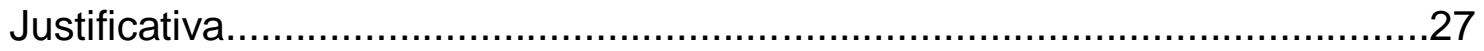

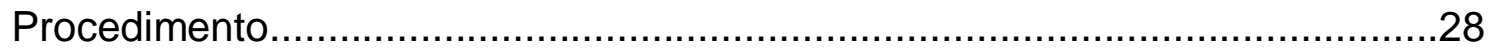

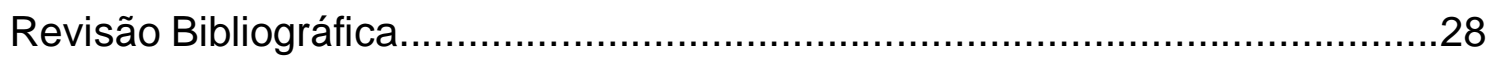

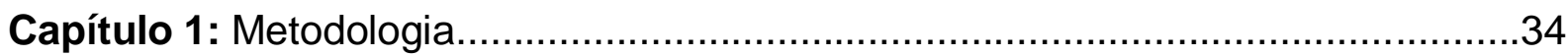

Capítulo 2: Família: uma visão clínica assentada na ética......................................39

Capítulo 3: Cotidiano: abertura ao inédito como possibilidade de intervenção............54

Capítulo 4: Família e clínica no Acompanhamento Terapêutico..................................66

4.1 Possibilidades de atendimento familiar na clínica do Acompanhamento

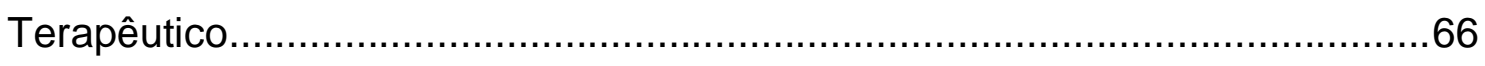

4.2 Família e a importância do gesto na clínica do Acompanhamento Terapêutico: um encontro entre gerações........................................................79

4.3 Vampirismo Familiar: Introjeção Extrativa e Duplo Vínculo.............................89

4.4 A família no setting do Acompanhamento Terapêutico.................................98

4.5 Não vá tão longe: a metáfora do combustível.........................................110

4.6 Família e contratransferência na clínica do Acompanhamento

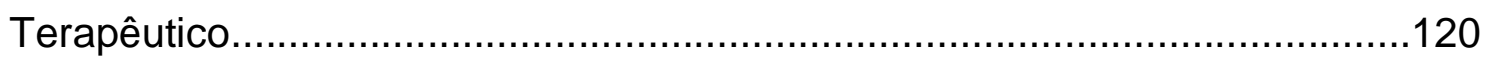

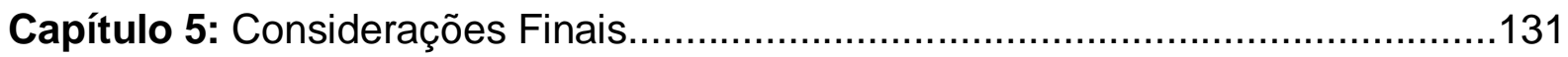

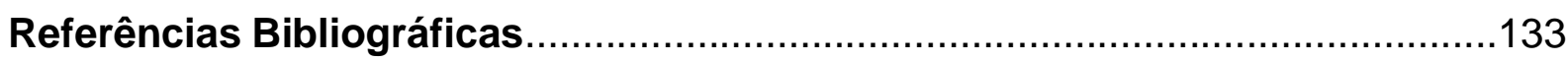





\section{Introdução}

O interesse pelo tema família, especialmente no campo do Acompanhamento Terapêutico (AT) surgiu durante os entraves, questionamentos e reflexões que foram aparecendo em minha prática clínica a partir do contato com a família dos pacientes acompanhados.

Pode-se observar que as questões relativas à família atravessam o tratamento dos pacientes de quatro formas: 1) no próprio contato com a família, nos atendimentos realizados em consultório; 2) na presença dos familiares durante os acompanhamentos, quando realizados em ambiente domiciliar e extradomiciliar; 3) na fala do paciente sobre a própria família, e por último; 4) nas questões apresentadas pelos pacientes durante os atendimentos.

Muito embora o Acompanhamento Terapêutico tenha permanecido por muito tempo e, predominantemente, vinculado aos casos de psicose, atualmente tem sido indicado a diversos tipos de pacientes, cujas dificuldades de socialização irrompem em grande sofrimento psíquico e existencial. Além dessa indicação, a prática clínica do Acompanhamento Terapêutico tem desbravado outras esferas para além das dificuldades de socialização. A exemplo dessa nova perspectiva, temos a entrada dos acompanhantes terapêuticos no âmbito do judiciário, onde realizam um importante trabalho junto às Varas de Família. Nesses casos, nem sempre a entrada do acompanhante terapêutico objetiva a inserção/reinserção social do paciente (perspectiva localizada na origem do Acompanhamento Terapêutico e relacionada diretamente ao campo da saúde mental) mas sim, e sobretudo, a auxilia-lo no trânsito e nos relacionamentos dentro de seu próprio núcleo familiar. A gama de possibilidades para a entrada do acompanhante terapêutico é vasta, não cabendo nesta dissertação especificar os diversos âmbitos possíveis de atuação desta modalidade clínica.

Antes de adentrar mais profundamente no tema proposto desta dissertação, penso ser importante mencionar o início de meu percurso atrelado à clínica do Acompanhamento Terapêutico ainda na graduação, assim como a visão de ser humano na qual me baseio para compreender os conflitos vivenciados pelos pacientes acompanhados e suas famílias.

No quarto ano do curso de Psicologia, iniciei estágio em Psicodiagnóstico Compreensivo, sob supervisão do professor Dr. Fernando Genaro Jr. Antes deste 
estágio, havia estudado diversas teorias psicológicas e a psicanálise mais clássica, nas matérias anteriormente cursadas na graduação. Ter aula com esse professor foi um marco em minha formação, pois ele apresentou uma compreensão clínica mais integrada e contextualizada do sofrimento humano. Foi através dele que conheci as obras do autor Donald W. Winnicott, pediatra e psicanalista inglês e do professor Gilberto Safra, psicanalista e pesquisador do Instituto de Psicologia da Universidade de São Paulo.

Percebia uma lacuna nas teorias psicanalíticas que consideravam o indivíduo a despeito de seu ambiente e história. Senti pela primeira vez, em contato e graças a esse professor, uma clínica "viva". Convencia-me, cada vez mais, de que falar de psicanálise sem falar de ambiente ou do contexto ao qual o indivíduo estava inserido, era um grande equívoco em nossa área. Esse professor e os dois autores referidos por ele (Winnicott e Safra), possibilitaram que eu revisitasse todo o meu universo interno e conseguisse dialogar de maneira mais integrada com a psicologia. Muito do que eu pensava sobre a vida, sobre as relações pessoais e sobre a clínica era contemplado na obra desses autores, tornando-se uma experiência de profundo encontro.

No campo do Acompanhamento Terapêutico, o meu contato inicial com essa modalidade clínica se deu na disciplina de Psicopatologia Geral ministrada pela professora Ma. Luciana Goldman. Em uma de suas aulas apresentou esse referido campo de atuação e, a partir do livro Acompanhamento Terapêutico: que clínica é essa? (Carvalho, 20014) e do filme Perfume de Mulher (Brest, 2004), promoveu uma conversa em sala de aula para que pudéssemos discutir nossas primeiras impressões sobre a clínica do Acompanhamento Terapêutico. Nessa disciplina, realizamos o primeiro estágio em Hospital Psiquiátrico e, apesar de o estágio não ser em AT, pudemos experenciar um outro modelo de atendimento que acontecia em um setting diferenciado em relação ao espaço de cuidado mais preservado do consultório. Ali, no contato com a loucura, eu já me atentava ao fato de que emergia e se tratava de uma clínica diferenciada da que estávamos habituados a escutar nas primeiras disciplinas da graduação. Ao chegar ao hospital fui recepcionada de uma forma bem inusitada por um dos pacientes: ele estava nu e pedia-me um abraço. Uma de minhas amigas que fazia parte do nosso trio de atendimento, sem nunca ter conversado com o 
paciente - que passava naquele momento ao seu lado - foi surpreendida com um soco na cara.

No último ano de faculdade, elegi como estágio a disciplina de Acompanhamento Terapêutico sob a supervisão do professor Dr. Kleber Barretto, o qual também apresentou uma clínica embasada nas concepções teóricas de Gilberto Safra. Além disso, este professor tinha um estilo bem peculiar de transitar na clínica, apresentava-nos um modo sempre leve e despretensioso de encontrar o humor nas coisas mais simples do cotidiano. Ter aulas com ele foi uma experiência especial, dada a sua sensibilidade em conduzir com humor e respeito o grupo de supervisão, permitindo que o aluno desbravasse os seus próprios caminhos e estilo na clínica do Acompanhamento Terapêutico. Paralelamente a essa experiência na Universidade, também fui convidada pelo psicanalista Dr. Ricardo Telles de Deus a fazer parte de uma miniequipe, na qual pude experenciar, pela primeira vez, como se daria o Acompanhamento Terapêutico na prática.

Através da prática clínica e dos estudos nos quais fui me aprofundando, deparei-me com a questão familiar que se pôs como um dos maiores desafios nos atendimentos em Acompanhamento Terapêutico. Obviamente, muitas questões surgiam no contato com os pacientes atendidos nos programas de estágio tanto em psicanálise quanto em Acompanhamento Terapêutico, mas o que mais me intrigava era a relação de dependência à qual estes pacientes estavam submetidos e a influência desse fenômeno para o processo terapêutico deles. Aspecto que deflagrava a necessidade clara de que o trabalho terapêutico também fosse direcionado à família dos pacientes, uma vez que a questão da dependência em suas diversas dimensões parecia afetar de maneira significativa o processo como um todo. Nesse momento, questões importantes começaram a aparecer, tais como: qual intervenção poderia ser utilizada para aliviar a angústia dessas famílias? Caberia ao acompanhante terapêutico fazer isso? Como intervir, se o acompanhante terapêutico, em muitos casos, parecia ser o mais novo elemento perturbador na relação familiar? O que fazer, se ao encaminhar a família para acompanhamento psicológico, muitas vezes a mesma se recusava? Teria o acompanhante condições de realizar intervenções breves com essa família? Quais seriam as possibilidades e limitações? Essas indagações surgiam, inclusive, pela presença de um sintoma familiar recorrente na clínica do Acompanhamento Terapêutico, a saber, a interrupção dos atendimentos em 
um momento crucial do tratamento. Faria (2016) muito embora não trate sobre a clínica do Acompanhamento Terapêutico, aborda em importante contribuição o lugar dos pais na análise de crianças. Nesse sentido, apresenta assinalamentos pertinentes à relação do terapeuta com os pais, o que a meu ver, assemelha-se ao modelo transferencial também estabelecido entre acompanhante terapêutico e família:

(...) se a estrutura que está em jogo nas entrevistas preliminares das análises de crianças inclui os pais, exclui-los é uma intervenção. Quais seriam os efeitos dessa intervenção, que desconsidera as queixas e demanda dos pais? O que ocorre do lado dos pais, quando estes são excluídos do setting das análises de seus filhos? (p.86)

E mais:

O efeito da intervenção que exclui os pais é, muito frequentemente, que aquilo que não é escutado, da posição de cada um, irrompa nas análises dos filhos, causando interferências que os psicanalistas tendem a analisar como resistências. Os pais deixam de pagar, faltam, abandonam 0 tratamento. A possibilidade de ruptura na análise da criança, sempre colocada no horizonte quando a transferência dos pais não encontra, no manejo do analista, um ponto estável de sustentação, é um fantasma que costuma assombrar os psicanalistas que fazem essa opção. O que se encontra alienado no sintoma na criança transborda na transferência dos pais. (p.86)

É importante observar como a questão que muitas vezes surge ao psicanalista de crianças, também surge ao acompanhante terapêutico. O que isso quer dizer? Faria (2016) com muita sensibilidade assinala que não se trata apenas de uma resistência por parte dos pais, mas sim, sobre a escolha feita por alguns analistas em não oferecer aos pais um espaço de escuta para as suas questões, fazendo-os se sentirem excluídos. Questões, estas, aparentemente relacionadas à criança, mas como bem aponta a autora e psicanalista "embora sejam os pais que trazem a criança, nem sempre o psicanalista está atento ao fato de que a queixa dos pais envolve um sofrimento que é deles" (Faria, 2016, p.79). Tal como na análise de crianças, nós acompanhantes terapêuticos também realizamos entrevistas preliminares com os pais/família do acompanhado. Abordar a família por esse viés na clínica do Acompanhamento Terapêutico, no meu entendimento, parece de fundamental importância. Foi essa questão, inicial e primordialmente, que me ocupou desde o início de minha formação, nos primeiros estágios.

A família nos acompanhamentos estava ali, presente e de forma concreta. Nesse momento, a teoria winnicottiana do amadurecimento emocional ofereceu-me condições de compreender o modo de relação de dependência vivenciado por alguns 
pacientes. Sobre a relação de dependência inicial entre o bebê e a mãe, Winnicott (1965) assinala:

Pressuponho, também, a existência de uma mãe que seja sadia o suficiente para comportar-se naturalmente ${ }^{1}$ como mãe. Devido à extrema dependência emocional da criança, seu desenvolvimento ou sua vida não podem ser estudados à parte da consideração do cuidado que lhe é fornecido. (p.5)

Em casos nos quais a mãe, a família, ou quem quer que represente o ambiente familiar para o paciente acompanhado, no caso de também estar em estado de sofrimento psíquico, não estaria também carecendo de cuidados? Como manejar essa questão na prática clínica do Acompanhamento Terapêutico?

\section{Família}

A família enquanto primeiro grupo social influencia o modo de ser da pessoa, bem como as suas questões. A concepção de família em nossa sociedade ganhou ao longo da história diversos contornos e compreensões. Por muito tempo, o modelo parental clássico que consistia na estrutura familiar mãe-pai-criança foi tido como ideal em nossa sociedade (Bock, 2008). Freud (1914-1916) formulou sua teoria com base nesse modelo familiar, no qual a função primordial dos pais na dinâmica psíquica dos filhos consistia em ofertar a triangulação necessária à vivência do Complexo de Édipo. Ainda que não houvesse pai e mãe, essa função poderia ser exercida por qualquer outra pessoa que pudesse interditar o desejo do filho investido em um dos pais do sexo oposto. De acordo com Filho (2010), Freud teoriza acerca de um sistema familiar que assume caráter institucional, simbólico e inconsciente. Como bem apontam, Rodriguez \& Gomes (2012):

"A abordagem psicanalítica atribui importância vital à família de origem, como as internalizações dos pais da infância e do modelo parental de relacionamento, e coloca em relevo a capacidade de cada indivíduo relacionar-se e vincular-se." (p 31).

${ }^{1}$ Há um equívoco por parte de alguns profissionais na compreensão do conceito winnicottiano de "mãe suficientemente boa", pois segundo o psicanalista a mãe suficientemente boa não é aquela que busca a perfeição, mas sim, aquela que age naturalmente conseguindo estabelecer uma comunicação significativa com o seu bebê. 
O termo parentalidade têm sido utilizado com frequência na contemporaneidade para referir-se às novas possibilidades de configurações familiares, uma vez que, "distingue-se da noção de paternidade por não estar relacionado ao modelo tradicional de família, retirando a ênfase do vínculo biológico e dos papéis sociais, enfatizando o processo de construção psíquica e vincularidade." (Rodriguez \& Gomes, 2012, p. 31). Pontuar brevemente essa discussão sobre o termo parentalidade parece importante, pois coloca em questão o que se entende por família e se ela acontece somente pelos vínculos sanguíneos ou se os transcende.

No campo da Psicanálise pós-freudiana, o pediatra e psicanalista inglês D. W. Winnicott, trouxe para o campo da psicanálise reflexões importantes sobre a família, a partir de sua experiência clínica no atendimento a mães e bebês. Desta perspectiva, formulou a teoria do amadurecimento emocional, tendo como base os cuidados destinados à criança durante os primeiros meses de vida. Em sua teoria, reflete sobre o sentido de ofertar ao bebê condições favoráveis para a constituição e estabelecimento do que viria a chamar de self.

Winnicott (1965) frisa que o bebê carrega uma tendência inata ao crescimento, e que dependendo da relação entre ele e sua mãe, por vias extremamente complexas, o mundo representado por ela pode vir a auxiliar ou impedir sua tendência inata ao crescimento. A esse respeito Winnicott (1990) nos esclarece sobre a importância de ofertar ao bebê a continuidade de experiência, conferindo a ele sensação de existência (estabelecimento do self):

O mundo interno é dotado de uma estabilidade própria, mas as mudanças
que nele ocorrem estão relacionadas a experiências do self global no mundo
dos relacionamentos externos. Experiências insatisfatórias levam a
existência e ao fortalecimento de coisas e forças sentidas internamente como
más. A criança sabe de sua existência e ameaça por uma sensação de dor
ou doença, ou pela diminuição do limiar de tolerância ao desconforto
sensorial. (p.104)

Desse modo, o campo da psicanálise é inaugurado a partir de questões ambientais outras, as quais localizam-se em estágios anteriores ao conflito edipiano. Outra referência importante ao nosso trabalho é um dos pilares da clínica contemporânea do psicanalista Safra (2004), a qual se fundamenta na ética ${ }^{2}$ enquanto

\footnotetext{
2 Ética: "etimologicamente derivada da palavra ethos, que nesse contexto refere-se aos sentidos de morada e pátria." (Safra, 2004, p.26)
} 
cuidado, bem como nas condições favoráveis ofertadas ao paciente para que seu devir ${ }^{3}$ possa acontecer. E diz:

Ao voltarmos o olhar para a situação clínica, veremos que ela se caracteriza pelo cuidado que estabelece as condições necessárias ao acontecer humano. Esses são fatos que me levam a afirmar que a clínica é essencialmente ética e a ética é clínica! (p.27)

A partir dessa perspectiva, o autor em diálogo com a teoria winnicottiana, que compreende a necessidade de acolher o bebê em sua chegada ao mundo, entre outras condições para que ele possa "vir a ser", acrescenta à complexidade da clínica outros registros para além do ôntico, rumo ao devir, e diz: "há outras facetas fundamentais para que o acontecimento humano possa dar-se" (p.40). Refere-se, nesse momento, a Sobórnost, enquanto registro ético, comunitário:

\begin{abstract}
A noção de indivíduo leva frequentemente a uma compreensão do ser humano como ontologicamente isolado dos demais. Sobórnost assinala que cada ser humano é a singularização da vida de muitos (...) A verdade de si mesmo acontece e se revela somente pelo reflexo do rosto do outro. Em nossa maneira habitual de pensar, o ser é constituído antes da comunidade. Sobórnost assinala-nos que o ser é comunidade! Em algumas escolas de Psicanálise há referência à importância do outro na constituição da subjetividade. (p.43)
\end{abstract}

Safra (2004) aponta que não bastam os cuidados familiares, apesar de necessários, pois "sendo o ser humano pura precariedade, necessita de um outro que o recepcione no mundo humano e que Ihe oferte o cuidado" (p. 40), mas sim, e sobretudo, que a pessoa tenha recepção humana em sua chegada. Segundo o autor, quem não vivencia esse registro no decorrer da vida pode vir a adoecer gravemente.

$\mathrm{Na}$ maioria das vezes, e principalmente nos casos mais graves encaminhados para atendimento em Acompanhamento Terapêutico, o paciente apresenta a necessidade, por vezes, de ser incluído no "humano" (Safra, 2009). São compreensões que ultrapassam a psicanálise e que, segundo este autor, colocam o clínico frente ao ser, de maneira ontológica, comunitária.

Bello (2006), em seus estudos também aborda o conceito de comunidade, importante para a compreensão da constituição do ser pessoa, do ser humano:

\footnotetext{
${ }^{3}$ Devir é uma concepção clínica utilizada por Safra que carrega o sentido de vir-a-ser.
} 
(...) a partir da comunidade como centro de referência para todas as associações humanas, do ponto de vista da antropologia filosófica e através da análise das vivências, nós chegamos ao ser humano singularmente considerado, nós identificamos sua estrutura como uma estrutura universal, não somente como estrutura pessoal. Há uma abertura ao outro, a muitos outros, aos grupos humanos. (p.83)

Segundo Safra (2004), essa abertura por parte da pessoa em reconhecer que o outro somos nós, é anterior aos processos mentais e psíquicos, pois faz parte da condição humana e, portanto, pode ser acessada por todos, independentemente da idade e/ou estado psíquico no qual a pessoa se encontra.

Abordar a clínica do Acompanhamento Terapêutico por este vértice, a meu ver, parece ser de fundamental importância, pois inaugura uma forma de pensar a família para além dos vínculos sanguíneos, corroborando com a concepção anteriormente apresentada de parentalidade, na qual independente da ligação sanguínea que se tenha, o que se pretende é destacar a importância da figura parental que assumiu os cuidados com a criança e/ou pessoa. Safra (2004) vai além, considera a comunidade humana enquanto parte da constituição do ser pessoa, reposicionando-a ontologicamente ao destacar a importância de se ter essa abertura ao que habita o outro e ao mesmo tempo, todos nós. Saliento que esse tema será melhor abordado no Capítulo II - Família: uma visão clínica assentada na ética.

\section{Diagnóstico Ambiental}

$\mathrm{Na}$ prática clínica da psicoterapia, assim como no Acompanhamento Terapêutico, são realizadas as primeiras entrevistas preliminares com a família e acompanhado, tendo em vista uma das etapas do processo de diagnóstico clínico. Winnicott, estabelecia o diagnóstico clínico a partir do estágio maturacional em que o paciente se encontrava. Segundo Moraes (2008), Winnicott: "apoiado em sua teoria do amadurecimento pessoal, observou que, sem as condições de ambiência iniciais adequadas às necessidades do bebê, as pessoas podem crescer fisicamente, mas permanecerem relacional e emocionalmente imaturas" ( $p .87)$. Tendo como base esse pressuposto, é possível identificar não somente as condições psíquicas do paciente acompanhado, como também as condições ambientais que favoreceram ou não sua constituição psíquica. 
O acompanhante terapêutico ocupa um lugar "privilegiado", no qual quase tudo vê, quase tudo escuta, quase tudo sente e quase tudo passa. Entende-se que "a presença do AT, além das conotações positivas que costuma ter para a família no início, adquire também a de intrusa. A família costuma sentir-se examinada, invadida ou espionada no seu ambiente natural" (Mauer; Resnizky, 1987, p. 86). Essa intimidade estabelecida no cotidiano com o paciente e sua família pode vir a gerar sofrimento ao acompanhante, pelo caráter da relação transferencial.

Na introdução de seu livro Natureza Humana, Winnicott nos relata, entre tantos desafios, as intercorrências da prática clínica no contato direto com os pais de seus pacientes: "fazendo a ligação entre todas as coisas, esteve a constante necessidade de dar conselhos a pais e mães que me consultavam, e foi essa parte dos meus afazeres que me pareceu a mais difícil” (1990, p.22). Na prática clínica do Acompanhamento Terapêutico, os acompanhantes também são convidados pela família a darem opiniões, orientações e explicações sobre o comportamento do paciente. Muito embora, a meu ver, o acompanhante não deva ocupar esse lugar de "orientador", em alguns momentos parece ser de fundamental importância escutar esse pedido por parte da família e considerar que tal movimento é reflexo de uma angústia vivida por ela.

Nessa prática clínica é comum também ocorrer certa indiscriminação dos papéis exercidos pela natureza do contato, por isso da importância de supervisão e análise pessoal. A experiência mostra que com o tempo tudo se mistura: cachorro, vizinho, panela, acompanhante, família, barulho. Quando menos se espera o acompanhante terapêutico está inserido nessa trama/teia familiar, questionando realmente qual é o seu lugar. Apesar de não haver apenas um lugar, mas muitos lugares que podem ser ocupados (ou melhor seria dizer "lugares pelos quais se transita"?), núcleos, potencialidades presentes nos acompanhantes, assim como nos pacientes e famílias. $O$ fato é que transitar por esses lugares sem se perder no registro terapêutico parece ser um desafio...

\section{Placement}

Dando continuidade à importância do ambiente no Acompanhamento Terapêutico, recorremos às formulações de Winnicott (1987) as quais tratam da 
influência do ambiente sobre as crianças evacuadas de seus lares durante o período da Segunda Guerra Mundial. Designado como Psiquiatra Consultor do Plano de Evacuação Governamental na Inglaterra, participou do processo de transição das crianças que precisaram ser transferidas de seus ambientes domiciliares para serem realocadas em outro lugar a fim de não serem atingidas pelos bombardeios da época. Esse trabalho, possibilitou a Winnicott testemunhar o quanto a transição de ambiente para algumas crianças foi benéfica, sendo compreendida por ele em um primeiro momento como "uma intervenção associada ao manejo, para mais à frente alcançar o estatuto de uma modalidade de atendimento clínico específica." (Safra, 2006, p. 16). Percebeu-se, a partir dessa experiência, que o novo ambiente com aspectos mais saudáveis - continuidade e estabilidade - ofertavam a algumas crianças a possibilidade de inaugurarem novas experiências emocionais e colocar a experiência disruptiva (vivenciada anteriormente em seus lares) sob o domínio do ego (Safra, 2006).

Safra (2006) resgata esse importante conceito na clínica winnicottiana, trazendo luz à possibilidade que o Acompanhamento Terapêutico oferta ao paciente de um lugar no mundo. O acompanhado, a partir de sua singularidade e com o auxílio do acompanhante, vai podendo re-significar e muitas vezes inaugurar, experiências que antes não encontravam "lugar".

O termo Placement cunhado por Winnicott (1987), está para além da transferência do paciente de um espaço físico para outro com aspectos mais saudáveis (Safra, 2006). É a oferta do lugar que possibilita a continuidade do ser, para que a pessoa vivencie aspectos de si que não foram possíveis de serem vividos no ambiente de características adoecedoras. Safra (2006) aponta a questão do lugar ético no Acompanhamento Terapêutico enquanto possibilidade de ofertar ao paciente, na relação estabelecida com este e através do encontro, a humanidade que estivera ausente em sua história e que "desabrocha" ao encontrar um olhar humano, o qual reflete amparo às suas questões favorecendo o seu processo de devir.

O Acompanhamento Terapêutico, em alguns casos, propicia experiências que inauguram dignidade na vida do paciente, no sentido do que the é devolvido humanamente na relação com o outro, e que confere sentimento de pertencimento, existência humana, possibilidade de relação com o mundo, com a vida. 
Esse aspecto da ética na relação entre acompanhante-acompanhado resulta em uma vinculação genuína, a qual, por vezes, pode vir a incomodar certos familiares. Mauer e Resnizky (1987) a esse respeito, assinalam:

Muitas vezes percebemos que o vínculo com o paciente pode gerar certo
"ciúme". Quando este vínculo vai se fortalecendo é comum ser percebido
como um relacionamento ameaçador para os familiares, como se o laço entre
acompanhante terapêutico e paciente pudesse impedir outras relações.
(p.85-86)

O acompanhante terapêutico acompanha a pessoa muito de perto, tal qual uma mãe em tempo de dedicação exclusiva que se dispõe a estar sensível às necessidades apresentadas por seu filho/a e que se comunica a começar pela corporeidade, conferindo sensação de segurança e continuidade. A família na figura de cuidadora acaba sentindo-se ameaçada quando percebe que o familiar acompanhado faz parte de uma relação de cuidado de outra ordem, tendo em vista o seu crescimento legítimo.

A concretude dos cuidados disponibilizados ao paciente durante os acompanhamentos, em muitos casos, refere-se a conteúdos ainda muito primitivos na organização de self deste e que, a meu ver, devem ser acolhidos e cuidados pelo acompanhante terapêutico. O processo é semelhante ao do bebê que a partir dos cuidados físicos vai sentindo segurança no mundo e tendo experiência de confiar. Winnicott (1990) nos esclarece que nos momentos iniciais de vida do bebê existe um ambiente caracterizado, antes de tudo e sobretudo, pelos cuidados físicos que são dispensados a ele, "a mãe foi responsável pelo ambiente no sentido físico do termo antes do nascimento, e após o nascimento a mãe continua a prover o cuidado físico, o único tipo de expressão de amor que o bebê pode reconhecer no princípio." (Winnicott, 1990, p. 122).

Também no Acompanhamento Terapêutico esse modo de comunicação relacionado ao desenvolvimento emocional primitivo entre acompanhanteacompanhado é de fundamental importância, uma vez que os efeitos terapêuticos dessas intervenções abrem possibilidades infinitas não somente à constituição psíquica da pessoa, como também ao reconhecimento por parte do paciente da abertura genuína do acompanhante para atender suas necessidades, promovendo a partir do que é humano e sensível, o encontro. 
De que maneira a questão da oferta de lugar aparece na clínica do Acompanhamento Terapêutico? Seria possível que esse lugar também fosse ofertado à família do paciente? Essas são questões que pretendo levantar no decorrer desta dissertação.

\section{Objetivo}

Apresentar, através de narrativas literárias sintéticas de casos clínicos, considerações sobre o lugar da família na clínica do Acompanhamento Terapêutico.

\section{Justificativa}

Tendo como concepção central a importância da família ou do ambiente que a representa na constituição do indivíduo, essa pesquisa procura compreender de que modo a família se organiza (ou desorganiza) em torno dos atendimentos realizados na modalidade clínica do Acompanhamento Terapêutico. A experiência tem demonstrado que a maior parte dos casos atendidos apresenta uma demanda de intervenção não apenas individual, como também familiar. Nos atendimentos, há condições de avaliar o ambiente com proximidade, ao mesmo tempo em que se torna necessário pensar possibilidades de manejo, dada a intensidade contratransferencial apresentada como fator relevante dessa clínica.

Apresentar considerações que contemplem possibilidades de intervenção junto à família do acompanhado confere ao campo do Acompanhamento Terapêutico uma perspectiva que está para além da preocupação clínica somente com o acompanhado. Perspectiva esta, que contempla a amplitude do campo, considerando aqueles que mais tempo convivem com o paciente. Segundo Bello (2006):

\footnotetext{
Uma família, por exemplo, poderia ou deveria ser uma comunidade. Mas nem sempre o é, entretanto se realiza como comunidade quando o vínculo entre os membros da comunidade é positivo, começando pelos sentimentos. No caso da família, o sentimento fundamental é o amor e sua reciprocidade, pois existe um desejo solidário de realização, mas se isso não acontecer, não há comunidade familiar. (p. 74)
}

Quando não se encontra na família do acompanhado essa relação de comunidade, em que cada membro se sente solidário em relação ao sofrimento e às 
questões do outro há, a meu ver, um imenso trabalho a ser feito. Percebe-se em algumas famílias o estabelecimento de uma relação opressora, a qual interfere significativamente no processo de Acompanhamento Terapêutico dos pacientes atendidos.

A figura do acompanhante então, passa a fazer parte de um projeto de comunidade, sendo intermediador entre acompanhado e família, acompanhado e mundo externo/sociedade. Nesse momento, começa a se desenhar uma preocupação em comunidade de destino ${ }^{4}$, a partir da inauguração do vínculo entre acompanhanteacompanhado, o qual ressoará tanto dentro da família, quanto para além dela.

\section{Procedimento}

Partindo de minha experiência clínica de aproximadamente dez anos como acompanhante terapêutica, serão apresentadas construções narrativas literárias sintéticas de casos clínicos, a fim de refletir sobre o lugar da família na clínica do Acompanhamento Terapêutico. Situações paradigmáticas serão apresentadas, a fim de construir possibilidades teórico-clínicas neste campo e, em particular, no que diz respeito à presença familiar nesta clínica.

As construções literárias são oriundas de casos clínicos e compreendem atendimentos a pessoas com idade entre os quatro e oitenta anos. Todas as narrativas serão apresentadas em forma de construções literárias. Serão mantidos os cuidados éticos previstos pelo Conselho Nacional de Saúde, Resolução nำ196 de 10 de outubro de 1996, incluindo o sigilo de identificação dos pacientes, os quais serão apresentados, nesta dissertação, apenas através de nomes fictícios.

\section{Revisão Bibliográfica}

Em primeiro livro publicado sobre o tema, Acompanhamento Terapêutico e pacientes psicóticos: manual introdutório e uma estratégia clínica (Mauer, S. K ; Resnizky, S, 1987) já é possível observar breves assinalamentos sobre a árdua tarefa

\footnotetext{
${ }^{4}$ Perspectiva apresentada por Safra (2004) relacionada à Sobórnost em que: "tudo o que uma pessoa faz, tudo o que pensa, tudo o que é, não está referido somente a um indivíduo, mas a todas as pessoas que a constituíram. A fala de um é texto de muitos. (...) estamos em registro ontológico! Trata-se do fato de que o ser humano é ontologicamente nós!" (p.68)
} 
do acompanhante terapêutico no contato com a família do paciente. Menciona-se o alívio inicial da família quando o acompanhante terapêutico inicia o trabalho junto ao integrante "adoecido", e posteriormente a isso, certa resistência ao tratamento (e também em relação ao acompanhante), quando o trabalho efetivamente começa a acontecer. As autoras foram precisas ao dizerem que "a relação do acompanhante com a família constitui para o primeiro um verdadeiro desafio e para enfrentá-lo deverá fazer uso de toda sua perspicácia e serenidade." (p. 87). Posteriormente, as mesmas autoras lançam novo livro para tratar de atualizações teórico-clínicas no campo do Acompanhamento Terapêutico, no capítulo "Famílias e vulnerabilidade psíquica" pontuam alguns desafios na prática do acompanhante inserido, segundo elas, em "famílias fragmentadas, com ideais questionáveis, desorientação identificatória, déficit na parentalidade, vacilações nos pais" (Mauer, S.; Resnizky, S, p.143, 2008). Abordase $o$ fato de que, quando se recebe um paciente grave em crise, recebe-se também uma família adoecida por essa ter esgotado todas as possibilidades de contenção do problema vivido. Além disso, o paciente que comumente necessita ser atendido nessa modalidade clínica representa, invariavelmente, o "sintoma de uma estrutura familiar igualmente comprometida" (Mauer, S; Resnizky, S. 2008, p. 27). Em Territórios do Acompanhamento Terapêutico (Mauer, S; Resnizky, S. 2009), percebe-se uma proposta diferenciada do canal de entrada dos acompanhantes terapêuticos na família, pois em vez de ser uma indicação para um membro que se encontra adoecido, a indicação do Acompanhamento Terapêutico acontece através de um dos integrantes da família que já está em processo de análise pessoal. São dois os casos relatados pelas autoras, nos quais as acompanhantes auxiliam o paciente que está em análise a lidar com os filhos, assim como com situações que envolvem impasses do cotidiano familiar. Ou seja, nesse caso, é a própria família que contrata o serviço de Acompanhamento Terapêutico para auxiliá-la com alguma demanda que a está adoecendo ou pode vir a adoecer, e não o contrário, em que a família é quem contrata o serviço do acompanhante terapêutico para atender algum integrante da família em estado de sofrimento psíquico. Nesse sentido a entrada do acompanhante, segundo as autoras, é para "apoiar uma família" (Mauer, S; Resnizky, S. p. 88, 2009). Em importante contribuição Mauer \& Resnizky (2011) nomeiam de "acompanhamento situacional familiar" a abordagem que compreende enquanto objeto de intervenção a família inteira. 
Em relação às primeiras contribuições brasileiras, o livro $A$ Rua como espaço clínico (Equipe de Acompanhantes Terapêuticos do Hospital-Dia A Casa, 1991), traz a importante discussão do tema sob um enfoque humanista das relações familiares. Apresenta-se um caso clínico no qual as autoras problematizam a influência da família nos atendimentos de uma paciente diagnosticada com transtorno borderline e uso abusivo de drogas. Pontua-se o sentimento inicial de raiva das acompanhantes terapêuticas em relação à família da acompanhada, uma vez que testemunham o descaso com o qual a paciente é tratada, assim como o estado de abandono em que se encontrava no momento inicial do Acompanhamento Terapêutico. Importantes temas são levantados, tais como se o acompanhante terapêutico deveria ou não lidar diretamente com a família do acompanhado; a presença de sentimentos de ambiguidade por parte da família em relação ao trabalho do acompanhante terapêutico; possíveis manipulações da família no momento em que percebe a vinculação entre acompanhante-acompanhado e a necessidade de um posicionamento firme e ao mesmo tempo flexível do acompanhante no contato com os familiares, aparece brevemente nesse capítulo incitando interrogações ilustrativas da tensão presente como problemática na incipiente clínica do Acompanhamento Terapêutico da época. No capítulo "A inserção do autista no meio social: relato de um caso" o autor apresenta as condutas e diretrizes terapêuticas utilizadas e relaciona diversas intervenções realizadas no caso, dentre elas a orientação aos pais. Ao final do capítulo pontua brevemente desdobramentos que envolveram a família do acompanhado e diz: "na medida em que foi alcançando progressos os desajustes dos demais membros foram surgindo e, nesse conjunto destaco fundamentalmente os transtornos da mãe" (Equipe de Acompanhantes Terapêuticos do Hospital-Dia A Casa, p. 184, 1991). Em capítulo posterior "O setting e as funções no acompanhamento terapêutico: o caso Júlia", o tema família é novamente abordado. Problematiza-se o fato de o acompanhante terapêutico ter sido "contaminado" por uma demanda que envolvia o desejo da mãe e não da paciente acompanhada, de modo que contratransferencialmente se sentisse afetado e perseguido pelo que foi denominado pelos autores de a "ordem da mãe", impedindo de tal forma que o espaço da paciente emergisse.

Mais tarde, em importante contribuição para o campo, Barretto (1998), um dos autores do último capítulo citado acima, aborda tal modalidade de atendimento pelo 
vértice da teoria winnicottiana, propondo a partir desse referencial teórico uma sustentação para a prática clínica do acompanhante terapêutico. Apesar de não inserir diretamente discussões sobre a presença da família nesse contexto clínico, refere-se a uma intervenção importante na qual a "ausência" da mãe em determinado atendimento possibilitou ao paciente, através do incentivo dado pelo acompanhante terapêutico e com o seu auxílio, a realizar uma atividade doméstica nunca antes experimentada. A meu ver, essa pequena vinheta clínica, a do paciente passando pela primeira vez as suas calças para sair, ilustra um exemplo clássico na clínica do Acompanhamento Terapêutico, no qual pacientes que dependem excessivamente de seus familiares acabam sendo "roubados" da possibilidade de realizarem atividades triviais que os fariam sentirem-se mais seguros e menos infantilizados. Do mesmo modo, observa-se também um movimento recorrente por parte dos pacientes de se acomodarem nessas situações. É nesse momento que, a intervenção do acompanhante terapêutico pode contribuir na possibilidade de visitar o novo, de construir novas perspectivas, ainda que sejam pequenas ações para quem as observa de fora, são certamente passos importantes àqueles que estão dentro da situação. É possível observar uma queixa dos familiares em relação à dependência do paciente, porém quando o tratamento é iniciado nota-se que a própria família, em alguns casos, torna-se a maior incentivadora desse padrão de comportamento dependente, gerando, por assim dizer, ganhos secundários a ambas as partes.

No livro Textos, Texturas e Tessituras no Acompanhamento Terapêutico (Santos, 2006), temas importantes acerca da família são mais uma vez mencionados. Sentimentos transferenciais e contratransferenciais que atravessam o corpo do acompanhante terapêutico no contato com as famílias; sentimentos contraditórios por parte dos familiares com a entrada do acompanhante terapêutico, percebendo-o por vezes como "ameaçador e intruso" (Santos, 2006, p. 133); a importância da colaboração e do compromisso da família como fatores cruciais à continuidade e eficácia do tratamento, podendo ser indício de bom ou mau prognóstico do caso; a importância de sensibilizar os familiares quanto ao olhar que se tem sobre o paciente atendido, são alguns exemplos de questões levantadas e que sinalizam a importância da discussão do tema família para o campo do Acompanhamento Terapêutico.

Frank \& Dragotto (2012) iniciam breves assinalamentos sobre a família no livro Acompañantes: conceptualizaciones y experiencias em AT, em capítulo sobre 
adicções tratam a questão do incômodo familiar em relação ao acompanhante terapêutico; já no capítulo sobre o AT no âmbito do judiciário abordam a presença do acompanhante terapêutico em regimes de visitas controladas. Mendonça (2014) em importante contribuição acerca do tema apresenta em seu livro Acompañamiento Terapéutico y clinica de lo cotidiano o conceito de "transferência familiar" e discute o impasse da transferência e contratransferência com a família do acompanhado na clínica do Acompanhamento Terapêutico. Além disso, frisa o que denominou de "excesso materno" enquanto um dos grandes desafios encontrados pelo acompanhante terapêutico nos casos atendidos.

Em recente e significativa contribuição ao tema Frank e col. (2016) contemplam no livro Acompañamiento Terapéutico: clínica en las fronteras quatro capítulos que abordam a presença da família na clínica do Acompanhamento Terapêutico, a saber: "Abordajes en AT una mirada ampliada hacia la família"; "Acompañamiento dual, famílias complejas"; A postura familiar e o resgate da autonomia e das potencialidades de um usuário de CAPS: um estudo de caso" e "Resistencias familiares ao dispositivo de AT".

Ademais dos livros publicados, observa-se um aumento de trabalhos publicados em congressos nacionais e internacionais com esse tema. Mendonça (2011) problematiza o que apresenta como paradoxo da atuação contratransferencial do acompanhante terapêutico em relação à família do acompanhado; Cornejo (2012) explana um caso em que a acompanhante terapêutica colocava-se no lugar de filha de uma mãe que não era reconhecida enquanto tal por sua família; Frank (2013) aborda a família no Acompanhamento Terapêutico como parte do cotidiano dos pacientes e, portanto, importante para se pensar intervenções que a considerem; Andorno (2015) mostra as resistências familiares em relação ao dispositivo do Acompanhamento Terapêutico; Oliveira e Safra (2016a) apresentam a importância do gesto direcionado à família do acompanhado como possibilidade de intervenção; assim como a importância de ofertar um lugar à família na clínica do Acompanhamento Terapêutico (Oliveira \& Safra, 2016a); Brian (2017) discute a importância da inclusão familiar no dispositivo do Acompanhamento Terapêutico; Branco (2017) a partir de um caso clínico concebe a figura do acompanhante terapêutico enquanto mediador entre a família do paciente, os settings e os profissionais envolvidos no caso e Frank (2017) 
retrata a família, pelo viés dos efeitos e das incertezas inerentes ao trabalho do acompanhante terapêutico. 


\section{Capítulo 1 - Metodologia}

Em sua origem, o Acompanhamento Terapêutico surge enquanto ruptura em relação aos modelos tradicionais de atendimentos vigentes da época (Mauer \& Resnisky, 1998). O acompanhante terapêutico, desde então, inicia o seu trabalho tendo como referencial um "não-saber" a partir do qual terá que avaliar como proceder em cada caso. O caráter experimental dessa prática clínica conferiu desde o seu princípio algo de inusitado ao campo. Apesar disso, inicialmente as tentativas de construção teórica encontravam-se fundamentadas em referenciais teóricos já instaurados.

Algo importante a ser observado na clínica do Acompanhamento Terapêutico é o pedido costumeiramente realizado no momento inicial de encaminhamento do paciente. O discurso da família, tanto quanto do profissional que o encaminha, é de que tentativas anteriores se fizeram em vão, passando a vislumbrar nessa modalidade de atendimento uma possibilidade outra para o que antes não encontrava horizonte. É como se o acompanhante terapêutico antes mesmo de conhecer o paciente já entrasse em missão. Missão essa historicamente contida em sua origem, a qual se baseou em estabelecer uma terapêutica a partir de outra perspectiva capaz de fazer frente a uma demanda que ainda encontrava-se em aberto, à espera.

O contexto de origem dessa prática clínica nos fornece indícios dos caminhos metodológicos a serem percorridos. É comum testemunharmos na prática do Acompanhamento Terapêutico embasamentos teóricos sempre relacionados a escolas teóricas já consagradas. Com isso, acredito que se perde de vista o que há de mais rico e profícuo em sua essência, em sua singularidade tanto nômade, quanto inédita. Penso haver um equívoco quando tentamos transpor, sem que antes haja certa crítica, conceitos da clínica psicoterápica e/ou psicanalítica à atuação do acompanhante terapêutico. Baró (2011) refere-se ao que denomina de "mimetismo cientificista" à tentativa de incorporação de modelos teóricos tendo em vista o reconhecimento científico, sem com isso considerar a historicidade do fenômeno a ser estudado:

A aceitação acrítica de teorias e modelos é, precisamente, a negação dos fundamentos mesmo da ciência. $E$ a importação a-histórica de esquemas conduz à ideologização de certas definições, cujo sentido e 
validade, tal como nos lembra a Sociologia do Conhecimento, remetem a certas circunstâncias sociais e a certos questionamentos concretos. (p.185)

A importância em reconhecer o que há de singular na clínica do Acompanhamento Terapêutico, marcada pelos desafios de uma prática complexa frente às diversas variáveis contidas no setting, revela a necessidade de considerar uma construção teórico-clínica própria deste campo. Incorporar, ou ainda nas palavras de Baró (2011), "mimetizar" aquilo que fora construído anteriormente em outro contexto e aplicar sem critérios ao novo pode incidir em um equívoco não ingênuo, mas antes de tudo e sobretudo, perverso epistemologicamente por desconsiderar os fundamentos daquilo que se apresenta.

Movimento semelhante parece ter se dado também com a entrada de investigações psicanalíticas na universidade. Safra (2001) destaca a importância da pesquisa psicanalítica nos espaços acadêmicos e explana o percurso histórico até chegar ao que hoje é conhecido dentro da Universidade de São Paulo como linha de pesquisa, por "Investigações em Psicanálise". Segundo o autor, houve um longo caminho percorrido até chegar no que existe hoje, em termos de fomento à pesquisa nessa área. O autor problematiza a construção de conhecimento inerente à psicanálise, dizendo:

(...) importante é a colaboração que a psicanálise traz à universidade por meio de um outro modelo de fazer ciência. Nele o rigor é encontrado não pelo controle de variáveis, mas pela fidelidade a um paradigma, a um vértice epistemológico. Os trabalhos produzidos a partir desses princípios, surgem como textos que se articulam em um determinado estilo característico de seu autor. (...) o pesquisador precisa investigar para além do conhecido, produzindo um trabalho que revele sua autoria e autonomia de pensamento. (p. 174-175)

Os acompanhantes terapêuticos estariam sendo reconhecidos em seu modo de fazer ciência? Seria possível tratar de uma clínica tão complexa, enquadrando-a tão somente em postulados teóricos já existentes sem com isso abrir perspectiva para o novo? Compreendemos que a clínica do Acompanhamento Terapêutico em sua idiossincrasia, tanto quanto em seu caráter originário de prática disruptiva assemelhase nesse sentido ao movimento de quebra de paradigmas similar ao que foi também a entrada da psicanálise nas universidades. Nesse sentido, penso que há uma urgência em reconhecermos os modelos metodológicos que contemplam a inscrição 
do novo dentro das universidades, a fim de que as novas pesquisas sejam validadas e reconhecidas a partir de seus pressupostos epistemológicos.

Destacamos o método de pesquisa qualitativo-abdutivo que, diferentemente dos métodos indutivos e dedutivos, abre caminho para um processo perceptivo visando a construção do novo (Dresch, 1998). "A dedução prova que algo deve ser; a indução mostra que alguma coisa é realmente operativa; a abdução simplesmente sugere que alguma coisa pode ser "(Peirce, 2005, p.220). De acordo com Boaventura (1987), é possível pensarmos no cenário científico atual como um período de crise do paradigma dominante. Segundo o autor, a ciência que se estabeleceu até aqui teve como lugar central a matemática e a física, e, portanto, as Ciências Naturais como fonte em sua construção epistemológica, derivando disto duas consequências:

\footnotetext{
Em primeiro lugar, conhecer significa quantificar. O rigor científico afere-se pelo rigor das medições. As qualidades intrínsecas do objeto são, por assim dizer, desqualificadas e em seu lugar passam a imperar as quantidades em que eventualmente se podem traduzir. O que não é quantificável é cientificamente irrelevante. (p. 28)
}

Boaventura (1987) afirma que a "revolução científica" que estamos vivendo atualmente é diferente da que ocorreu no século XVI e defende que o paradigma a surgir dessa vez necessitaria de um cuidado ético. Menciona a urgência de um paradigma de conhecimento denominado por ele como prudente, no qual seja considerada a dimensão social, referindo-se a ele, nessa perspectiva, enquanto conhecimento "decente". Em Epistemologias do Sul (Boaventura \& Meneses, 2010), coletânea de textos que conta com a contribuição de diversos pesquisadores, especialmente os da América Latina, são discutidos os modos de colonização de conhecimento que foram sendo constituídos durante séculos. Uma linha claramente segregadora dividia o sul do norte, considerando a epistemologia dominante positivista desta última como superior em relação à produção de conhecimento da primeira.

De acordo com esse cenário, penso ser importante haver discussões acerca da necessidade de um novo olhar dentro da universidade para a produção de conhecimentos mais prudentes, como afirma Boaventura (2010), e menos segregados, tanto quanto mais condizentes à prática e realidade do próprio pesquisador. Espaços onde se tenha mais lugar para a complexidade do que para o reducionismo (Safra, 2004; 2006; 2014), e que a partir dessa reflexão possa ser 
construído (enquanto se desconstrói) algo para além do que foi alcançado até aqui (ou melhor seria dizer, perdido?).

Nesse sentido, propõe-se na presente pesquisa a utilização do método qualitativo, o qual busca "criar um modelo de entendimento profundo de ligações entre elementos, isto é, falar de uma ordem que é invisível ao olhar comum" (Turato, 2005, p.509), com o objetivo de investigar questões inerentes à prática clínica do acompanhante terapêutico e que envolvem a presença familiar na clínica do Acompanhamento Terapêutico.

Serão construídas narrativas literárias sintéticas de casos clínicos a fim de explanar situações paradigmáticas que envolvem a família na clínica do Acompanhamento Terapêutico. O método utilizado é orientado pela análise das relações "acompanhante terapêutico-família" e "família-acompanhado".

A clínica contemporânea de Gilberto Safra carrega enquanto fundamento ético a necessidade de abertura do profissional para a complexidade apresentada pelo paciente, tanto quanto para o inédito que se mostra na situação clínica. Tal pensamento clínico oferece subsídios para a sustentação da presente pesquisa, pois permite que o novo, além de ser apresentado, seja considerado em sua singularidade, indicando possibilidades de caminhos a serem percorridos. A construção teóricoclínica deste autor, amplia a compreensão do que é ser pessoa, reposicionando a clínica de maneira polifônica, uma vez que mantém a tensão das diversas vozes ao sustentar o que há de mais paradoxal na constituição humana. Segundo Safra (2004) "somente o paradoxo contempla a condição humana como ser no mundo e sempre para além dele" (p. 44). Além disso, inscreve a ética como rigor na clínica atual em que fraturas éticas nesse sentido atravessam o ser. Para Safra (2006) "há facetas daquilo que chega até nós que estão para além do que foi reprimido ou foi significado em algum momento de nossas vidas. Pelo fato de o ser humano ser transcendência, está sempre atravessado pelo inédito. "(p.25). A concepção clínica deste teórico, a meu ver, converge para os fundamentos da clínica do Acompanhamento Terapêutico, uma vez que propõe um olhar assentado na ética do encontro, ao mesmo tempo em que considera a complexidade dos fenômenos apresentados na clínica.

A escola inglesa de psicanálise representada por D. W. Winnicott também auxiliará o percurso metodológico da presente pesquisa, pois inaugura no campo psicanalítico importantes conceitos para a clínica do Acompanhamento Terapêutico, 
tais como: a teoria do amadurecimento emocional primitivo, a comunicação significativa entre paciente e terapeuta, a importância do ambiente na constituição psíquica do indivíduo, os processos de dependência absoluta e relativa, o ódio na contra-transferência, entre outros.

Em relação às construções teóricas específicas da modalidade clínica do Acompanhamento Terapêutico, contamos tanto com a colaboração de autores brasileiros (Barretto, 1997, 1998; Equipe de acompanhantes terapêuticos A Casa, 1991; Santos, 2006; Tufolo, 2014; Oliveira \& Safra, 2016; Branco, 2017), quanto argentinos (Mauer \& Resnizky, 1987, 2008, 2009, 2011; Cornejo, 2012; Frank \& Dragotto, 2013; 2016; Bustos, 2016; Andorno, 2015; Brian, 2017), assim como espanhol (Mendonça, 2011, 2017).

As referências bibliográficas da presente dissertação resultam em um encontro entre as antigas e incipientes apostas de trabalho com a família na clínica do Acompanhamento Terapêutico e as novas reflexões que têm surgido enquanto possibilidade de atuação do acompanhante terapêutico nesta clínica. 


\section{Capítulo 2 - Família: uma visão clínica assentada na ética}

A singularização do ser humano assenta-se na situação originária que o constituiu. Safra

O capítulo inicial abre a discussão do que será abordado em capítulos posteriores. Penso que a visão que concebo sobre família e as suas possíveis implicações à constituição do ser humano tiveram origem não em minha formação como psicanalista e acompanhante terapêutica, mas antes de tudo, e sobretudo, em minha biografia. Encontrei nas concepções clínicas de Safra e Winnicott fundamentos de trabalho que se assemelham ao modo como compreendo o ser humano e a vida. Neste capítulo, farei um panorama geral, desde o ponto que assumo como o início do meu interesse pelo tema tenha surgido, para em seguida fundamentar, a partir da construção teórica desses dois autores, as vicissitudes inerentes aos adoecimentos familiares encontrados na clínica e suas possíveis interferências na constituição e subjetivação do paciente. Penso que tal recorte, tendo em vista o que os autores abordam sobre organizações familiares adoecidas, torna-se primordial na sustentação teórica dessa pesquisa, uma vez que observamos que os casos encaminhados para Acompanhamento Terapêutico dizem respeito não somente a pacientes adoecidos, como também e principalmente, às famílias adoecidas.

Ao adentar a casa das pessoas, em meu exercício profissional como acompanhante terapêutica, lastimei muitas vezes 0 fato de os pacientes acompanhados não terem em suas vidas um irmão, um avô, um cachorro, um dois pais psiquicamente saudável, um amigo ou quem quer que fosse, para lhes garantirem alguma possibilidade de sanidade mental em meio ao caos. Em minha experiência, pude observar famílias bastante adoecidas e na maioria das vezes até mesmo mais adoecidas do que o próprio paciente. Sempre senti o fato de os pacientes acompanhados não terem alguém em suas vidas que lhes cuidasse, Ihes enxergasse, Ihes amasse. Não me refiro aqui ao sentido romantizado do termo, mas sim ao que compreendo, a partir das concepções clínicas de Safra e Winnicott, enquanto ética do cuidado.

Desde o início dos atendimentos, no encontro com os pacientes, havia sinalizações do que ali, para eles, havia faltado em termos de relação com o outro. À medida que os acompanhamentos transcorriam, o vínculo entre acompanhante 
terapêutica e acompanhado se estabelecia. Naquele momento, a transferência se instaurava e os pacientes me colocavam exatamente onde eu deveria estar. Alguns me identificavam como acompanhante, outros como uma amiga de infância, mãe, psicóloga, irmã, e assim por diante, a depender do que havia Ihes faltado em sua história pregressa, ou até mesmo a figura que havia sido mais significativa em sua história. Penso que, muitas vezes visitei o meu próprio sofrimento e disso surgia a empatia com o sofrimento e a dor dos pacientes acompanhados. Enquanto isso acontecia, a família estava ali, sempre em meu horizonte. Em minha prática clínica, localizo enquanto maior desafio a construção de um lugar ético ofertado à família do acompanhado, lugar esse que contemple também o cuidado em relação a todo o sofrimento familiar. Em alguns casos, o desafio com a família parecia infinitamente maior do que com o paciente acompanhado; este último parecia responder aos cuidados ofertados e tudo parecia fluir a partir da vinculação genuinamente construída. O que nem sempre acontecia no contato com a família do acompanhado - pelos motivos que serão abordados detalhadamente nos capítulos seguintes.

Sempre tive em meu horizonte a importância de se ampliar o convívio do paciente com o seu entorno, a incluir a própria família do acompanhado quando esta o permitia. Localizo em nossa formação no campo da psicologia uma visão que tende a excluir a família no trabalho com o paciente, mais do que a inclui-la. Por vezes, adquirimos também essa postura sem nos darmos conta, o que a meu ver, exige uma vigilância de nossa parte para não incorrermos em tal equívoco.

Como bem sabemos, é premissa básica do Acompanhamento Terapêutico ampliar espaços de circulação. Aqui cabe uma observação importante, pois à medida que o paciente circula em novos espaços desbrava também caminhos internos nunca antes percorridos. É o interno e o externo que vão se retroalimentando a todo instante, penso que essa potência é característica da clínica do Acompanhamento Terapêutico. Não obstante, até que isso aconteça, há algo anteriormente mais importante, a saber, a construção de uma relação de confiança entre dois (acompanhante e acompanhado). Como bem observou Winnicott (1941), há um período de hesitação por parte do paciente, característico do processo terapêutico que consiste no estabelecimento de confiança no ambiente. Essa seria uma condição, a priori, para que o paciente se arriscasse, antes de tudo e sobretudo, a ser ele mesmo para só então fazer uso do objeto (analista-acompanhante). Nesse sentido, as contribuições 
da psicanálise inglesa, a partir de Winnicott (1958, 1965, 1982, 1983, 1987, 1989, 1990), que propõe o cuidado sob demanda, assim como a psicanálise contemporânea, a partir de Safra (2004), que propõe um modo de relação assentada na ética fizeram e fazem todo o sentido em minha formação como psicanalista e acompanhante terapêutica. Atualmente, temos autores que contextualizam a família na contemporaneidade (Gomes, 2009; Rodriguez \& Gomes, 2012; Roudinesco, 2003; Saraiva \& Mandelbaum, 2017) e problematizam as novas formas de organização familiar. Muito embora tal discussão seja fundamentalmente importante, em minha experiência como acompanhante terapêutica percebi que os adoecimentos familiares estavam muito mais sujeitos à falta de uma relação baseada na ética entre os membros, do que relacionadas a novas formas de configurações familiares. Porquanto, os casos atendidos referiam-se tanto a organizações familiares tradicionais, cujo modelo vigente era o nuclear, quanto a organizações familiares mais contemporâneas. Sendo assim, irei utilizar as concepções teóricas de Winnicott e Safra por entender que contemplam de forma mais específica, tanto quanto paradigmática, o contexto clínico ao qual me refiro nesta pesquisa.

Winnicott (1983) dedicou grande parte de seu trabalho na discussão do processo maturacional do bebê a partir da relação dual com a mãe. A experiência que teve em pediatria favoreceu a descoberta de processos maturacionais importantes na constituição psíquica do bebê, a qual se tornaria, mais tarde, também uma forma de organização psíquica na vida adulta. Aliou à sua prática em pediatria o conhecimento psicanalítico, e desde então algo importante foi inaugurado na história da psicanálise.

Neste capítulo, refletiremos sobre as contribuições de Winnicott e Safra acerca de determinadas organizações familiares, principalmente àquelas nas quais algum dos membros, ou todos, encontram-se adoecidos. Safra (2004) discorre sobre as relações nas quais o bebê teve em sua chegada ao mundo uma recepção problemática da comunidade humana, representada inicialmente pelos pais, muito embora não restrita a eles. Abordaremos, então, quais seriam, dentro da perspectiva desses dois autores, as implicações desse adoecimento familiar, para a pessoa acompanhada.

Em seu livro A Família e o Desenvolvimento Individual Winnicott (1965) relata casos nos quais se depara com famílias muito adoecidas e, por conseguinte, adoecedoras tanto para o paciente quanto para o analista que as atende. Coloca em 
questão o manejo necessário do analista no atendimento a elas e a importância de se fazer um estudo de caso detalhado tendo em vista a melhor forma de proceder clinicamente. Ressalta diversos modos de organização familiar e as consequências para o tratamento da criança quando um dos pais, por exemplo, apresenta uma organização psíquica relacionada à psicose.

Winnicott teve importante inserção na área social, especialmente durante a Segunda Guerra Mundial, quando foi designado como Psiquiatra Consultor do Plano de Evacuação Governamental na Inglaterra, onde atendeu crianças que haviam sido evacuadas de seus lares. O envolvimento com a área social se deu tanto através de seus enfrentamentos profissionais, como também em seu segundo casamento com Clare Winnicott, assistente social. Penso que a sua inserção no âmbito social, assim como a experiência em atendimentos a diversos bebês, crianças, adultos e famílias em contextos institucionais e de sofrimentos diversos, possibilitou a construção de uma técnica que se adequasse às necessidades apresentadas por cada paciente. Em alguns casos chegou a denominar o seu trabalho de análise modificada, a qual era conduzida a depender da demanda de tratamento apresentada por cada paciente. No âmbito social, por exemplo, o acesso que teve às famílias o fez considerar a seguinte questão:

Em qualquer serviço social de caso, deve-se tomar uma decisão: qual é a pessoa doente neste caso? Ainda que seja a criança, às vezes é outra pessoa que causou e está mantendo a perturbação, ou então pode ser que o problema seja um fator social. (Winnicott, 1989, p.124)

Essa singularidade de Winnicott - estar sempre aberto às questões que ultrapassam os conflitos intrapsíquicos - possibilitou perceber a relevância do ambiente sobre o adoecimento da criança, quer fosse pela influência dos pais (microssocial), assim como pela inserção em sua comunidade (macrossocial). Nesse sentido, Winnicott ampliou a compreensão dos conflitos para além do registro intrapsíquico, colocando desta forma, o ambiente externo como um elemento importante a ser analisado na compreensão do sofrimento vivenciado pelo paciente.

Winnicott apresenta duas possibilidades de adoecimento nos pais e menciona que $\mathrm{o}$ analista poderá avaliar a pertinência de trabalhar em conjunto com a família a depender do diagnóstico. Classifica as famílias da seguinte forma: 1) um dos pais é psicótico; 2) um dos pais é depressivo e; uma terceira situação, na qual 
compreende que muito embora um dos pais esteja adoecido, ainda assim este carregaria condições de contribuir no tratamento da criança. A seguir, iremos apresentar, a partir deste autor, como cada adoecimento familiar interfere no desenvolvimento da criança, assim como as implicações posteriores ao processo terapêutico.

\subsection{Sobre pais psicóticos}

A psicose presente em um dos pais exige, em certos casos, que o cuidado com a criança seja outorgado a outrem. $O$ cuidado pode ser assumido tanto no ambiente intrafamiliar, quando alguém mais próximo à criança assume os cuidados com essa, quanto fora do ambiente familiar. Winnicott (1989) compreendia que uma das facetas do trauma se referia ao fracasso à dependência, afetando sobremaneira a possibilidade de o bebê vir a desenvolver a capacidade de confiar no ambiente externo. O trauma para esse teórico seria a ausência de um ambiente seguro (holding), ou seja, a falta de continuidade dos cuidados sustentados no tempo e no espaço.

Segundo o psicanalista, a psicose parental pode apresentar variações, as quais exigem que 0 analista as identifique a fim de avaliar a possibilidade de os pais contribuírem ou não no tratamento de seus filhos. Como mostra a seguir:

\footnotetext{
(a) Pais muito perturbados. Nestes casos, outros indivíduos assumem o cuidado dos bebês e crianças.

(b) Pais menos perturbados. Há períodos em que outros entram em cena.

(c) Pais dotados de saúde suficiente para proteger os filhos da própria patologia, pedindo ajuda.

(d) Pais cuja patologia inclui a criança, de modo que nada pode ser feito por esta sem a violação dos direitos que todo pai tem sobre seus filhos. (Winnicott, 1965, p.113)
}

É interessante observar, segundo a proposta de Winnicott, que em alguns casos, apesar do adoecimento de um ou ambos os pais, ainda assim haveria a possibilidade de cooperação deles no tratamento de seus filhos justamente pelos núcleos adoecidos presentes e compartilhados entre eles. Winnicott (1965) menciona um caso no qual o pai da criança tinha esquizofrenia e que justamente por esse fato o pai pôde identificar-se com a loucura do filho. A mãe da criança que também fora acometida por certo adoecimento, e precisamente por isso, também pôde contribuir 
na primeira fase do tratamento de seu filho permitindo que o mesmo se fundisse a ela. No entanto, quando o limite dessa mãe já estava próximo, Winnicott transferiu a criança de seu lar para poder trabalhar aspectos da segunda etapa do tratamento, utilizando, portanto, aspectos fundamentais do ambiente na promoção de saúde da criança atendida.

Às vezes, pais descompensados psiquicamente vão constituindo com seus filhos relações nas quais somente suas próprias necessidades são atendidas em detrimento das necessidades de seus filhos, gerando assim uma inibição na criança (e mais tarde adulto) em funcionar a partir de um desejo mais próprio (Prota, 2010). Nesses casos, pode haver o aparecimento de culpa na criança quando esta percebe desejar algo mais legítimo sem que haja a necessidade de atender às demandas externas. A esse respeito Winnicott (1965) refere-se ao desenvolvimento do falso self de algumas crianças em situações de psicose parental:

\begin{abstract}
A psicose nesse caso está num ou em ambos os pais, e constitui-se de tal modo que a única esperança da criança passa a ser o desenvolvimento de um falso self; é claro que o filho pode morrer antes dos pais, mas, de toda forma, seu self verdadeiro terá conservado sua integridade, permanecendo oculto e resguardado da violência exterior. (p. 99)
\end{abstract}

Safra (2004) também apresenta situações nas quais o adoecimento familiar interfere no processo de constituição dos pacientes atendidos. Esclarece-nos que "uma das necessidades fundamentais do homem no estabelecimento de seu ethos é a de ser recebido no mundo humano pelo Outro" (Safra, 2004, p.127) e que, "a recepção que cada bebê encontra estará marcada pela possibilidade que sua família tem de estar enraizada, em cada uma das dimensões do ethos humano" (Safra, 2004, p.127). Denominou de "fraturas éticas originárias" os problemas encontrados pelo bebê em sua chegada ao mundo e que interferem, sobremaneira, em seu processo de devir. Safra (2004) faz uma sistematização das fraturas que observa na clínica contemporânea, dentre as quais uma delas corrobora com a concepção de Winnicott ao descrever o bebê que se depara com a mãe em estado de adoecimento:

A mãe adoecida tende a sofrer excessivamente com a aproximação de seu bebê. Isso o leva a uma preocupação com sua mãe, que acontece antes que ele pudesse chegar a essa experiência por meio de seu processo maturacional. Esse bebê, habitualmente, teme a própria vitalidade. A pessoa desenvolve-se excessivamente preocupada com o outro, o que lhe retira a espontaneidade necessária ao viver. $\mathrm{O}$ analisando necessita reencontrar, na 
situação clínica, a intensidade de sua vida instintiva e alcançar, na relação transferencial, o amor primitivo. (p. 132)

Safra (2004) também aponta a importância de considerar no processo clínico dos pacientes atendidos o ambiente com características intrusivas, isso indicaria a apresentação precoce de uma realidade objetiva em detrimento de uma realidade subjetiva necessária ao processo de amadurecimento emocional do paciente. Sendo assim, ressalta:

Na maneira subjetiva, o bebê vive o meio ambiente como continuidade de si, situação que the dá a possibilidade de reconhecimento da realidade objetiva em seu tempo de maturação. No modo objetivo, o bebê percebe o outro como objeto, antes que tenha desenvolvido a noção de eu e outro, ou seja fora de seu processo maturacional. (Safra, 2004, p.129)

Essa compreensão sobre as condições ambientais necessárias ao desenvolvimento maturacional do paciente possibilita que intervenções nesse sentido sejam realizadas pelo analista/acompanhante terapêutico a fim de oferecerem um espaço potencial que contemple as necessidades que não foram atendidas no curso de seu desenvolvimento emocional. Outra forma de psicose observada por Winnicott, diz respeito aos pais que a mantém oculta projetando nos filhos aquilo que neles é pulsante:

(...) o êxito no tratamento de uma criança pode ser traumático para um ou ambos os pais. A psicose latente no adulto, que até então se mantivera oculta e adormecida, reaparece pela profunda transformação positiva operada na criança, e passa a exigir sua quota de atenção e aceitação. (p.93)

Winnicott (1965) difere as situações nas quais o pai é quem apresenta uma organização psicótica daquelas nas quais a mãe é quem apresenta. Em sua prática como pediatra verificou a relação de maior proximidade, a começar pela gestação, entre o bebê e a mãe. Nesse sentido, compreendia que o acometimento da psicose na mãe interferia de forma mais contundente na constituição psíquica do bebê.

Em casos mais severos de psicose parental Winnicott buscava avaliar a possibilidade de afastar a criança de seu núcleo familiar, a fim de proporcionar ambiência favorável para trabalhar aspectos importantes no tratamento. Menciona, inclusive, que para alguns pais essa alternativa se tornava um grande alívio, dado o adoecimento que os acometia. 


\subsection{Sobre pais depressivos}

O quadro depressivo em um dos pais costuma influenciar na disponibilidade afetiva destes para com o filho. Dentre os adoecimentos vivenciados pelos pais e que envolvem a depressão, o quadro maníaco-depressivo parece ser o que mais afeta a criança, dada a recorrente imprevisibilidade de humor que atravessa a relação (Winnicott, 1965). A partir desse funcionamento imprevisível por parte de um, ou ambos os pais, observou-se que a criança se sente insegurança em poder confiar no ambiente externo, estando ora desconfiada, ora retraída. O fator da inteligência e da predição parecem também estar interligados no que se referem aos quadros maníacodepressivos:

Como é natural, as crianças mais inteligentes têm uma vantagem sobre as pouco inteligentes no que toca à capacidade de previsão; mas às vezes constatamos que a capacidade intelectual de crianças muito inteligentes foi sobreexigida - a inteligência foi prostituída, concentrando-se apenas na complexa tarefa de predição dos humores e tendências paternos e maternos. (Winnicott, 1965, p. 111)

Sobre as crianças que vivenciaram tamanha instabilidade no ambiente de origem, Winnicott sugere que, muito provavelmente, tornar-se-ão adultos "precavidos", assim como no exemplo que nos dá de pessoas que costumam olhar para o céu ou escutar a previsão do tempo antes de saírem de casa. Como exemplo, acrescenta também um atendimento realizado por ele no qual o menino atendido olhou para o seu rosto e perguntou se estava cansado. O psicanalista refere que de fato estava cansado, mas que pretendia ocultar isto de seu paciente. Não foi possível, dada a sensibilidade do garoto em decifrar expressões faciais nos adultos. São crianças que crescem precisando identificar como os pais estão se sentindo para protegerem-se de possíveis mudanças que aparecem de súbito e sem causa aparente. A experiência, neste caso, é sentida pela criança como trauma (Winnicott, 1965).

Se pensarmos que a depressão patológica refere-se também à ausência de vitalidade em uma pessoa, sendo esta a mãe de um bebê que não consegue levar a cabo as atividades mais rotineiras de sua vida, podemos inferir a partir do que Winnicott diz sobre a importância do olhar na relação mãe/bebê, que a criança que convive desde muito cedo com uma mãe depressiva não encontra em seu olhar uma 
presença, mas sim uma ausência. São crianças que desde muito cedo deparam-se com questões complexas. Safra (2004) menciona a "mãe-objeto ausente" e explica que alguns pacientes se singularizam a partir da solidão:

\begin{abstract}
Nessa situação o bebê despenca no nada, sem o encontro com o Outro. Esse bebê conhece a experiência de solidão, precocemente, antes de alcançar a continuidade de ser e de ter noção de objeto. (...). Uma pessoa que viveu esse tipo de experiência não experimenta o sentimento de solidão, ela é a solidão. Do ponto de vista clínico, não basta trabalhar com essa solidão como se fosse decorrente de uma angústia de separação, de exclusão da cena primária ou de um ataque ao objeto. Essa solidão é anterior a qualquer uma dessas experiências psíquicas. Ela foi constitutiva! (p.131)
\end{abstract}

Observamos que para esse teórico o diagnóstico do ambiente sob o qual o paciente esteve e está inserido torna-se imprescindível para a compreensão do trabalho clínico a ser realizado com cada paciente. E mais, Safra explica-nos sobre a importância de reconhecer o que constituiu o paciente e o sentido disto na história de sua família, para que assim o paciente sinta-se reconhecido em sua questão "pelo Outro, o que o coloca do lado do destino humano e sob o domínio da criatividade" (Safra, 2004, p. 131).

Parece haver uma diferença entre o modo pelo qual Safra aborda as questões relativas ao adoecimento familiar, entre o modo pelo qual Winnicott as aborda. Dificilmente encontraremos na obra de Safra menções a diagnósticos, sejam eles de caráter psiquiátrico tanto quanto estruturais e/ou organizações psíquicas. Penso que esse modo de organizar e sistematizar os fenômenos que encontrou na clínica revela um olhar humanizador que enxerga em cada sintoma o seu respectivo sofrimento, muito mais do que uma preocupação com diagnósticos, geradores de estigmas. Além disto, não podemos esquecer a formação médica de Winnicott antes de sua formação como psicanalista.

\title{
2.3 Singularidades
}

Apesar de Winnicott reconhecer a vital importância do ambiente para o desenvolvimento infantil, reconhece por outro lado que cada criança é um ser único e singular, a despeito, inclusive e por vezes, do ambiente no qual está inserida. Cada bebê, assim que nasce, apresenta um ritmo e tempo próprios na relação com o outro. Safra (2012), em concordância com Winnicott, também assinala que antes da 
constituição psíquica do bebê algo já aponta para uma singularidade neste. Acredita que, antes mesmo do desenvolvimento da personalidade ali já existe uma pessoa que deve ser considerada em seu modo de ser. Isso explica porque a teoria winnicottiana sinaliza a importância de o ambiente adaptar-se ao bebê de forma singular e não uniforme, pois cada bebê deve ser compreendido como único em suas características próprias. Assim é a criança e mais tarde o adulto, que apresenta a sua pessoalidade, e em termos de cuidado, necessita de um acompanhar adaptado ao que esteja em consonância com isso. Nesse sentido, seria importante que o pai, a mãe ou quem quer que esteja responsável pelos cuidados da criança, esteja conectado e identificado a esta. O que para um filho é acolhimento, para outro pode ser invasão. Para Winnicott, a mãe que se encontra em estado de "preocupação materna primária" é capaz de identificar as necessidades primárias do bebê, e assim, atendendo-as favorece que o desenvolvimento de seu self aconteça (Winnicott, 1958; 1965; 1982; 1983; 1989 e 1990). Nota-se em alguns casos, que apesar da gravidez tranquila alguns bebês apresentam maior agitação desde a gestação. Esse viés apresentado pela teoria winnicottiana é de fundamental importância para compreender que não se trata de um modo ideal de cuidado destinado à toda e qualquer criança, há diferenças que dizem respeito ao ambiente, bem como diferenças que estão vinculadas à singularidade de cada criança. Nesse sentido, Winnicott (1965) esclarece a importância de se ter em vista o que é do ambiente, e o que é da criança atendida:

Devemos lembrar, porém, que o distúrbio da criança pertence apenas à criança, embora as condições ambientais devam ser levadas em alta conta na consideração da etiologia do problema. A criança pode encontrar meios de crescer sadia apesar dos fatores ambientais, e pode sofrer distúrbios, não obstante o bom cuidado. Quando fazemos com que uma criança seja afastada de pais psicóticos, temos a esperança de poder trabalhar com ela; raras são as vezes em que se constata que a criança é normal quando afastada do genitor doente. (p.108)

É interessante observar que, ao mesmo tempo em que Winnicott valoriza a compreensão do ambiente na etiologia do distúrbio apresentado pela criança, infere também sobre a relevância da singularidade da pessoa em interação com esse ambiente. Ou seja, em sua teoria considera o ambiente e o utiliza na compreensão do diagnóstico a ser realizado, mas também é capaz de o abster para que a singularidade do paciente seja desvelada. Segundo Winnicott (1965): 
(...) por mais que uma família faça tudo de melhor por um de seus filhos, isso não é garantia de que a criança vá desenvolver-se até atingir a plena maturidade. A economia interna de cada indivíduo pode apresentar seus próprios riscos, e a meta principal da psicoterapia individual é esclarecer essas tensões internas. (p. 135)

Safra (2004), amplia a discussão winnicottiana sobre a singularidade do paciente e problematiza o que viria a chamar de idioma pessoal, conceito de fundamental importância em sua clínica. Para esse teórico, tal perspectiva seria o que no paciente "aparece em sua maneira de ser, em seu discurso, em seu gesto, nas coisas que ele colhe para compor o seu ambiente, na maneira como ele constitui seu percurso de vida. "(p.116). Alerta-nos sobre o equívoco que há no fato de o analista se utilizar das teorias enquanto linguagem universal, o que acaba por gerar "uma forma de violência e de doutrinação, que impede ou aniquila o idioma singular do analisando. "(Safra, 2004, p.123). Nesse sentido, esclarece-nos que:

\footnotetext{
As intervenções do analista precisam aparentar-se com a semântica existencial do paciente (...). O analista é aqui não aquele que nomeia com sua linguagem as situações de vida do paciente. Ele, a partir de sua posição, do lugar singular que ocupa em sua existência, coloca em diálogo o que o paciente apresenta, na medida do possível, no registro do idioma pessoal do paciente. (p. 123)
}

Para esse teórico o idioma pessoal refere-se ao que foi constitutivo na vida da pessoa, e que, portanto, revela o modo pelo qual ela concebe a sua existência no mundo. Um paciente que desde a infância viveu de maneira solitária, pode sentir a solidão não como ausência, mas sim como presença e talvez até mesmo como sagrada, uma vez que isso o tenha constituído. De acordo com Safra (2006), o reconhecimento, por parte do clínico desse registro, faz com que o paciente se sinta considerado em sua mais profunda forma de existir. Esse modo de Safra conceber a clínica nos coloca frente a um grande desafio, pois no momento em que o sofrimento se apresenta precisamos reconhecer e discriminar o que é inerente ao idioma pessoal e que coloca o paciente em conexão com a sua essência, e portanto, em processo de devir, daquilo que é adoecimento e o afasta justamente daquilo que ele sente como fundante em seu ser. Em minha experiência pude observar que a própria organização do adoecimento carrega algo do idioma pessoal. Uma pessoa excessivamente preocupada com o outro, por exemplo, pode estar funcionando a partir de um falso self, mas também pode estar revelando algo que a constituiu e que para si na relação 
com o outro é sagrado ${ }^{5}$. Uma pessoa que trata as coisas da vida com certa rigidez pode estar impedindo que novas experiências sejam integradas, ao mesmo tempo, essa mesma pessoa pode se destacar em funções que exijam disciplina, revelando que o rigor é um valor fundamental em sua existência e que este a constituiu. Outro exemplo, são as pessoas que se organizam de maneira sensível ao sofrimento do outro, apresentando grande disponibilidade empática, e revelando, portanto, que a consideração pelo outro as constituiu. Porém, essa mesma pessoa pode vir a apresentar dificuldades em discordar e se posicionar frente a alguém que tenha uma opinião divergente, justamente por temer entrar em situações de possíveis enfrentamentos, sentindo que desconsideraria o outro e assim por diante...

Questão que me parece complexa tanto no trabalho realizado com os pacientes em consultório, quanto com os pacientes em Acompanhamento Terapêutico, por ser algo da ordem do paradoxo. Lispector (2002) dizia: "até cortar os próprios defeitos pode ser perigoso. Nunca se sabe qual é o defeito que sustenta nosso edifício inteiro" (p.165). Aquilo, portanto, que sustenta todo o sentido mais profundo de existência do paciente, pode ser também aquilo que por não ter sido destinado através de um Outro torna-se o próprio adoecimento (Safra, 2004):

\begin{abstract}
Enquanto clínicos, somos também chamados a compreender (como seres interpretantes que somos) o modo de ser daquelas pessoas que chegam até nós. Desta maneira, a pessoa que nos procura tem o seu modo de ser afetado por sua biografia e pelas questões que a atravessaram desde o seu nascimento. (...) este modo peculiar de interpretar o seu existir, afetado por seu modo de ser, é expressão da sua singularidade e constitui o que denomino de idioma pessoal. O idioma pessoal, portanto, é derivado do modo singular de uma pessoa, a partir do qual ela tem uma maneira peculiar de interpretar a existência e de emprestar às palavras, imagens e atos, uma semântica existencial pessoal. (...) considero importante que a situação clínica seja estabelecida a partir do idioma pessoal do paciente. O analista, trabalhando nessa perspectiva, poderá vir a ser informado e guiado pelo idioma pessoal do paciente. (Safra, 2006, p.26)
\end{abstract}

Ainda nessa perspectiva, Safra (2012) afirma que todo bom clínico é aquele que consegue ser um "poliglota", pois consegue dialogar com os diferentes idiomas pessoais apresentados por cada um de seus pacientes. Essa postura exige do analista/acompanhante terapêutico certa porosidade para adaptar-se ao paciente e assim estabelecer uma comunicação significativa. Winnicott (1998) no capítulo "A

\footnotetext{
${ }^{5}$ Termo cunhado por Safra para referir-se a experiência...
} 
comunicação e a não comunicação" também abordou a questão da comunicação significativa, a qual será esmiuçada no quarto capítulo desta dissertação.

\subsection{As fraturas éticas e o sofrimento humano}

Como já apontado anteriormente, Safra (2004) sinaliza a importância de oferecer ao bebê uma recepção humana em sua chegada ao mundo e assinala que é através dos pais que as questões fundamentais da família e da comunidade se apresentam ao bebê:

" Cada família proporcionará uma recepção peculiar ao bebê, matizada pelo que traz preservado de suas tradições, pelas questões que a atravessaram ao longo das gerações e pelo momento histórico em que o bebê chega." (Safra, 2004, p.127).

De acordo com o psicanalista, a família que não preserva a memória do ethos humano encontra-se fraturada eticamente, pois não consegue habitar o mundo a partir do que a constitui, conferindo desta forma, e por consequência, uma recepção problemática ao bebê. Safra (2004) corrobora com alguns pressupostos de Winnicott, ao afirmar que os pais e a família exercem importante função ao acolher o bebê em sua chegada, mas que isso acontece, primordialmente, na relação com a mãe. Diferentemente de Winnicott, Safra não sistematiza as formas de adoecimento familiar através de diagnósticos (pais psicóticos, pais depressivos, entre outros), mas sim, a partir de situações observadas na clínica que se tornaram singularizações do sofrimento familiar, por interferirem sobremodo na constituição dos pacientes atendidos. $\mathrm{O}$ autor sistematiza configurações de ambientes que promoveriam, por assim dizer, possíveis fraturas éticas. Dentre elas, apresenta as mais frequentes e frisa que tal sistematização não tem como objetivo esgotar as inúmeras possibilidades de recepção problemática ao bebê, mas sim, exemplificar, a partir de situações originárias a complexidade dos fenômenos apresentados. Abaixo alguns dos contextos de recepção problemática ao bebê:

a) a mãe que se apresenta ao bebê como um objeto intrusivo e que com a sua presença excessiva impede o aparecimento do gesto criativo no bebê - Safra (2004) compartilha da visão clínica apresentada por 
Winnicott na qual compreende que o bebê apresenta uma tendência inata ao crescimento, necessitando de condições ambientais favoráveis para que esse desenvolvimento aconteça. Um dos obstáculos a esse desenvolvimento pode ser a intrusão ambiental, a qual rouba da criança a possibilidade do gesto criativo. No decorrer de sua obra, Safra assinala a importância de considerar o singular em cada pessoa, sendo para este autor o aspecto criativo fundamental à clínica.

b) a mãe excitante que estabelece precocemente com o seu bebê uma relação de sedução, despertando precocemente o registro erótico e impedindo que a criança constitua desejos próprios;

c) a mãe-objeto ausente que faz com que o bebê conheça a experiência de solidão, precocemente, impedindo que ele alcance a continuidade de ser e de noção de objeto;

d) a mãe-repouso ausente que pela ausência da mãe meio ambiente e do holding, não confere a possibilidade de quietude e, consequentemente, experiência de ser à criança, favorecendo o aparecimento de organizações defensivas em torno da hiperatividade;

e) a mãe adoecida que sofre excessivamente com a aproximação de seu bebê, fazendo com que a criança se desenvolva excessivamente preocupada com o outro e não consiga ter a espontaneidade necessária ao viver;

f) a mãe-tecnológica que apresenta à criança um mundo sem presença humana, sem gestos e sem cuidados remetidos à corporeidade humana, fazendo com que a criança se desenvolva para fora do mundo humano "em um repúdio às configurações estéticas decorrentes da tecnologia" (Safra, 2004, p. 133);

g) famílias que vivem para alcançar prestígio social, que não recebem o bebê como alguém, mas sim como um objeto, um signo social que confere prestígio, fazendo com que a criança desenvolva um repúdio ao social ou um modo de existir em que sua personalidade é apenas "casca social" (Safra, 2004, p. 135);

h) o ambiente que infligiu à criança abuso psíquico, colocando-a em um estado de atordoamento capaz de promover confusão e dificultando o 
seu desenvolvimento psíquico e/ou mental em processos internos de discriminação;

i) o ambiente que ocasionou violência corporal e que fez com que a criança se organizasse por meio do medo e/ou da dor, carregando em si uma cicatriz;

j) o ambiente que violenta a criança através de abuso sexual fazendo com que ela desenvolva uma percepção ruim de si mesma, tonando-se introvertida e fugidia em relação aos aspectos de seu corpo e de seu psiquismo.

Esses são alguns exemplos, apresentados pelo psicanalista, de contextos originários que constituem o modo de ser do paciente, e por consequência, o modo pelo qual apresenta-se no encontro com o analista/acompanhante terapêutico. Ele afirma que todo paciente é história encarnada e que, "não é possível compreender sua questão originária, seu idioma pessoal, sua ontologia e teleologia se ele não é visto em sua historicidade constitutiva. "(Safra, 2004, p. 154). Safra (2004) ainda, diferencia as fraturas éticas originárias das fraturas éticas que podem ocorrer em momentos posteriores da vida. Essa diferenciação parece ser importante na clínica, uma vez que segundo o autor "é um profundo engano tratar de uma pessoa que vive sofrimento decorrente de uma situação acontecida em épocas posteriores de sua vida, como se fosse questão do início de sua vida" (Safra, 2004, p.137). Sendo assim, e segundo tal teórico, a forma pela qual o paciente se constitui é que dará indícios de como o seu processo terapêutico, seja no consultório na modalidade de psicoterapia, como na clínica do Acompanhamento Terapêutico, deve ser compreendido.

Neste capítulo, procurei abordar a partir das concepções clínicas de Winnicott e Safra, importantes contribuições acerca de organizações familiares que se encontram em estado de sofrimento psíquico. A partir desse referencial, iremos apresentar nos próximos capítulos articulações com a clínica do Acompanhamento Terapêutico. 


\section{Capítulo 3 - Cotidiano: abertura ao inédito como possibilidade de intervenção no Acompanhamento Terapêutico}

Esses são fatos que me levam a afirmar que a clínica é essencialmente ética e a ética é clínica! (Safra, 2000, p.27)

O presente capítulo tem como objetivo apresentar o modo pelo qual concebo, em diálogo com os autores que serão apresentados, a importância do inédito para a clínica do Acompanhamento Terapêutico. Compreendo que o tema família está estreitamente relacionado à concepção de cuidado, uma vez que a família é o primeiro grupo a oferecer cuidados a alguém (ou pelo menos à maioria das pessoas). Apesar de a família exercer a função de cuidadora, penso que este núcleo não tem a exclusividade - e nem poderia ter - de ser o únic responsável pelo processo de devir de uma pessoa. Tal perspectiva está diretamente atrelada à clínica do Acompanhamento Terapêutico, por tratar-se de uma clínica que acontece no cotidiano, o horizonte do que pode vir a ser cuidado e encontro se expande e transcende. Por vezes, os encontros significativos na vida do paciente não ocorrem dentro de seu ambiente familiar, e sim, fora dele. Nesse sentido, dividiremos o texto a seguir em duas partes, uma abordará o inédito na clínica do Acompanhamento Terapêutico, seguida de uma narrativa clínica. A segunda, explicitará por meio de uma narrativa situacional cotidiana o que entendo por encontro.

\section{Parte I}

Durante os acompanhamentos nos deparamos com situações inéditas que, inevitavelmente, transformam o curso do que muitas vezes havia sido pensado e/ou preparado inicialmente com o paciente. Abordar a amplitude do Acompanhamento Terapêutico em sua multidimensionalidade é importante para que não se restrinjam as oportunidades de intervenção durante os encontros. As intervenções durante os atendimentos nem sempre são realizadas pelo acompanhante, por vezes elas se dão no atravessamento de variáveis externas contidas no próprio campo, o que, diga-se de passagem, acontece com frequência. É preciso estar atento ao material que se 
mostra acessível durante os acompanhamentos, pois fazer uso dele pode ser fundamental e enriquecedor ao encontro.

A visitação do inédito durante os atendimentos pode surgir tanto na interação entre acompanhante-acompanhado, no despertar da relação intersubjetiva, como por meio de elementos externos que aparecem em campo. O inédito está presente na situação clínica, é revelação (Safra, 1995; 2004; 2005; 2006) e pode ou não vir a ser encontro, a depender da abertura e do manejo por parte do profissional, no momento em que o fenômeno se apresenta. Em consultório, os pacientes apresentam questões relacionadas ao cotidiano, enquanto que no Acompanhamento Terapêutico a clínica é o "próprio cotidiano".

Em conferência apresentada no VII Congresso Internacional de Acompanhamento Terapêutico, realizada em novembro de 2012 em São Paulo, a poeta Adélia Prado e o psicanalista Gilberto Safra, discorreram sobre o cotidiano enquanto horizonte de revelação e a sua importância para a vida das pessoas. Adélia afirmou que tudo o que se tem na vida é o cotidiano, pois é nele essencialmente que as pessoas se constituem, com as suas necessidades, paixões e percalços. Segundo ela, é a partir das experiências vividas dentro dele que surgem todas as perguntas, ele assola a todos, independente da classe social a qual estejam enquadrados, pois se trata de um problema humano. Parafraseando Carlos Drummond de Andrade, a poeta recordou o famigerado poema que diz: "tinha uma pedra no meio do caminho", entendendo que essa passagem diz respeito justamente aos conflitos inerentes às experiências do cotidiano. Adélia apresentou a concepção de que todo cotidiano pode vir a ser tanto céu, quanto inferno, e que essa é a grande aventura de natureza íntima. A epifania do cotidiano, segundo ela, conduz-nos a caminhos surpreendentes, e diz: "não precisa ir longe para buscar isso, isso está ao nosso redor, dentro de nós." (Prado, A.; Safra, G., 2006).

Gilberto Safra, por sua vez - compartilhando do mesmo pensamento de Adélia - reforçou a importância do olhar sensível às coisas do cotidiano. Esclareceu que o adoecimento se relaciona ao fato de as pessoas experenciarem o cotidiano enquanto lugar de funcionalidade e não enquanto lugar de revelação e presença humana. Nesses casos, segundo o psicanalista, o cotidiano torna-se mera repetição e a pessoa adoece pois não encontra formas de transformar o seu entorno; ocorrendo, portanto, um achatamento da experiência. Para ele, este é justamente o cenário de trabalho do 
acompanhante terapêutico, no qual auxilia os pacientes sem cotidiano a criarem algum. No entanto, não se trata de qualquer cotidiano, a grande questão que se coloca é que o acompanhante terapêutico precisará auxiliar o paciente a constituir um lugar no cotidiano carregado de sentido. Nas palavras de Safra (2006), o paciente tem a possibilidade de recuperar a sua pessoalidade através das pequenas experiências do cotidiano ofertadas pelo acompanhante terapêutico. Safra (2005) menciona Adélia Prado e assinala que a poeta busca "comunicar a seus ouvintes esse olhar que pressente a presença do ser nas coisas do cotidiano, nos objetos do mundo. (p.128)."

Também a obra winnicottiana também nos auxilia a pensar sobre a importância do cotidiano enquanto oferta de lugar a partir do qual a pessoa pode ter experiências significativas e, portanto, constitutivas na presença de um outro. Para Winnicott, o bebê se constitui através de experiências cotidianas que são significativas para o seu desenvolvimento: o colo, o olhar, a temperatura da pele de quem o segura, o momento da amamentação e/ou alimentação, todas essas experiências se dão no cotidiano e são sentidas pelo bebê como presença acolhedora e/ou intrusivas, a depender de como são conduzidas por quem o cuida.

Contextualizar o cotidiano e a sua importância para a constituição da pessoa na clínica do Acompanhamento Terapêutico parece-me fundamental para que se tenham claros os fundamentos dessa clínica. É através do cotidiano que a clínica do Acompanhamento Terapêutico se constitui e é inaugurada. Em seu bojo encontramos também a presença do inédito. Quando estamos com nossos pacientes, não sabemos o que será encontrado no meio do caminho, nem mesmo se chegaremos ao encontro; o que sabemos é que certamente estamos nos aventurando, cotidiano afora, cotidiano adentro. Durante os atendimentos, cada variável ou o conjunto delas, pode despertar um encontro, um incômodo-desencontro, dependendo da história de vida do paciente (seus medos, anseios, enfim, toda a sua singularidade). Creio que a experiência de ser acompanhante terapêutico passa por essa possibilidade de atravessar o cotidiano em um estado de abertura ao inédito. Parece-me que só assim, nesse estado de abertura ao surpreendente, é que as epifanias do cotidiano, como bem aponta Adélia Prado, acontecem. Safra (2004) também compartilha desse pensamento ao afirmar que para além do estado de abertura para o novo é preciso estar aberto para o mistério, concluindo que "a clínica é o lugar do surpreendente, da alteridade. Da abertura para o Outro!" (p. 147). 
Penso que muito já se falou e foi teorizado acerca do paciente no Acompanhamento Terapêutico, uma vez que essa construção é contínua. Porém, penso igualmente que é chegado o momento de ampliarmos nossas discussões no campo do Acompanhamento Terapêutico para além da dupla acompanhanteacompanhado.

De minha trajetória como acompanhante terapêutica, guardo na memória situações inéditas pelas quais passei ao lado dos acompanhados que se tornaram constitutivas não somente ao paciente, como também constitutivas à minha pessoa. No sentido de compartilhar com o leitor uma dessas situações, abaixo será apresentada uma narrativa clínica; pretendo demonstrar a presença do inédito no cotidiano e a importância desse evento na clínica do Acompanhamento Terapêutico, bem como a importância das intervenções que ocorrem por si mesmas, quando estamos em um estado de abertura ao surpreendente.

\section{A história do cachorrinho Bidu}

Naquele dia, Marcos e eu havíamos combinado de ir ao parque. Saímos de sua casa e aguardávamos a abertura do semáforo para atravessarmos a rua. Nesse ínterim, um garotinho aparentando dez anos de idade parou ao nosso lado. Estava aflito, com os olhos marejados de lágrimas e um cachorrinho no colo, que parecia machucado. Senti naquele momento que algo estava acontecendo e num impulso perguntei ao garotinho se estava tudo bem. Ele disse que não e explicou que o seu cachorrinho havia acabado de ser atropelado. Naquele momento, olhei para o paciente, na tentativa de buscar algo que me desse um sinal do que poderíamos ou não fazer, tendo em vista aquele contexto. Sereno, o paciente me olhou, e então perguntei se poderíamos ajudar aquela criança, ele prontamente respondeu que sim. Cabe ressaltar que, a pergunta direcionada a Marcos somente se deu porque eu enxergava em sua pessoalidade a abertura necessária para aquela situação. Eu poderia estar equivocada, obviamente, e justamente por isso resolvi lhe perguntar. Precisei me certificar e verificar se ele se sentiria confortável em tal circunstância. Caso a sua resposta fosse negativa, o rumo certamente teria sido outro...

Em cada caso percebemos a possibilidade que o paciente apresenta de fazer uso ou não, de determinadas situações em seu processo de devir. Destaco essa 
explicação, pois já acompanhei pacientes que não suportavam a presença de um terceiro que se achegasse, nesses casos sentiam-se como que violentados, normalmente eram pacientes com uma organização persecutória mais grave. Nesses casos, havia um cuidado de minha parte em não favorecer situações nas quais o paciente se sentisse exposto, não era o caso de Marcos, ele gostava e conseguia aproveitar bem, em alguns casos, os elementos externos.

Após a resposta afirmativa de Marcos, prosseguimos. O garotinho estava a caminho do veterinário, o acompanhamos. Assim que chegamos ao consultório, o veterinário informou que havia grande risco de o cachorrinho morrer de hemorragia. Realizou os primeiros socorros e nos pediu que o levássemos rapidamente ao pronto atendimento de veterinária da USP. Foi o que fizemos, correndo. Tudo foi tão rápido que não tivemos tempo para nenhuma formalidade, estávamos todos preocupados com o que ali se fazia urgente. No caminho, pude acompanhar uma cena muito bonita, a de Marcos acalmando o menininho que chorava com o seu cãozinho no colo. Ele dizia: "vai ficar tudo bem, você vai ver!" (sic).

Assim que chegamos ao prédio de veterinária da USP, fomos encaminhados para o preenchimento da ficha de atendimento. Nesse momento, fomos surpreendidos por uma pergunta óbvia: "o que vocês são desse menino?"

À época, ainda recém-formada e com pouca idade, ou talvez pela ânsia de resolver o que ali se fazia urgente, só após essa pergunta é que me dei conta de que não sabíamos nada sobre aquela criança, além do desespero que tinha em salvar o seu "amigo-cão". O chefe do centro de veterinária disse que não poderia atender àquele cachorro sem um responsável pelo menor que o acompanhasse, procurei conversar explicando do que se tratava, mas foi em vão. Até que o próprio garotinho encontrou uma forma legítima e desesperada de pedir socorro: nervoso que estava, desmaiou no chão da sala de espera. Somente assim os responsáveis do instituto consentiram o "pronto-atendimento" do cãozinho. Disseram-me que eu havia me arriscado muito, pois "em uma dessas" (sic) eu poderia ter sido acusada de sequestro de menores, e até mesmo ter sido presa. Fiquei sem reação ao presenciar tamanha falta de sensibilidade. Ao mesmo tempo, me perguntava o que eu deveria ter feito ao encontrar aquela criança desesperada que acabara de presenciar o atropelamento de seu cão? Talvez perguntado a ela onde estavam os seus pais? Qual era o seu nome? Onde morava? Enfim, nada disso passou pela minha cabeça naquele momento, o 
desespero da criança e o que ali se fazia urgente nos tomou por inteiro. Pensei: numa próxima (como se houvesse) tentarei lembrar de todas essas perguntas...

Durante toda a situação, Marcos buscava acalmar a criança, e também a mim (o meu desespero em relação a toda responsabilidade e preocupação que eu tinha, certamente transpareciam em meu rosto). Enquanto ficávamos na fila de espera aguardando o pronto-atendimento do cachorro, Marcos cantava. Cantava, mesmo quando tudo parecia explodir de preocupação. O menino, que também não sabia o nome de Marcos, o enxergava como verdadeiramente era, uma pessoa alegre, bemhumorada, atenciosa e de bom coração, sem estigmas de qualquer doença mental. Isso possibilitou ao Marcos uma dignidade jamais vivida, por exemplo, no seio de sua família. Naquele dia ele foi, e de maneira exemplar, acompanhante de nós...

O cachorrinho foi atendido e somente após ele ter sido cuidado é que o garotinho lembrou o telefone de sua casa. Ligamos para a sua mãe e explicamos todo o ocorrido. Voltamos todos, aliviados! Semanas depois a mãe do garotinho ligou para agradecer o que havíamos feito pelo seu filho e por termos salvado o cachorrinho que ele tanto amava.

Barretto (1998) ao abordar a importância de se favorecer aspectos criativos no encontro com o paciente ressalta que:

A criatividade é importante não só porque reconecta o sujeito ao mundo dos
objetos (realidade compartilhada), mas por possibilitar o (re) encontro do
sujeito com a sua vitalidade (seu estilo, suas características). A expressão
criativa, promove, então, o sentimento de estar vivo (sentir-se real) e
pertencer à espécie humana. (p.53)

$\mathrm{Na}$ situação vivenciada por nós quatro (cachorrinho, menino, Marcos e acompanhante terapêutica), apesar de toda a apreensão ocasionada pelo acontecimento, ainda assim - e mesmo assim -, foi possível acolher e dar vazão ao inédito que se apresentou. Isso possibilitou que Marcos se colocasse na vida de forma também inédita e vivenciasse em si registros que pouco tinha a oportunidade de experenciar em seu cotidiano, pois o estigma da doença mental sempre vinha antes de ele poder se relacionar com o outro a partir de si mesmo. Marcos não era visto no que havia de mais singular e especial em sua pessoalidade. Recorrendo a Winnicott (1983) podemos brincar com o paradoxo que ele propõe sobre a ilusão e dizer que criamos o que ali já existia, mas que precisava ser encontrado para poder de fato existir. Tal experiência proporcionou a Marcos visitar lugares antes jamais percorridos. 
Não era esse o lugar ocupado por ele em sua casa, em sua família, no CAPS com os outros pacientes, aonde quer que fosse. O lugar que the cabia era o de paciente, daquele que carecia de cuidados, apenas! A situação vivida possibilitou a Marcos oferecer auxílio, zelar e cuidar de quem carecia de sua ajuda. Penso que, se nesse momento o acompanhante terapêutico interviesse de modo a evitar aquele tipo de situação, roubaria a possibilidade de o paciente vivenciar a sua dignidade na relação com o outro. Ademais, agiria como alguns pais que superprotegem seus filhos, não permitindo que eles tracem o próprio caminho a partir das vicissitudes da vida.

Safra (2006a) nos explica que estar aberto ao inédito implica em um certo desconforto, uma vez que nos coloca em uma posição de desconstrução do si mesmo. Penso que essa visão clínica destaca a importância e a necessidade de o acompanhante terapêutico se posicionar sempre como eterno aprendiz. Essa preocupação enquanto fundamento da clínica é apresentada por Safra (2004):

Testemunhamos em nossos consultórios, ao longo dos anos, situações inusitadas, que colocam em questão nossas teorias e nossa prática clínica. Para fazer frente a essas questões e sermos fiéis a nossa vocação de clínicos, temos de nos posicionar como eternos aprendizes. O inédito e o singular visitam a cada dia nossos consultórios, ensinando-nos novas maneiras de caminhar em direção à revelação da condição humana. (p.21)

Acredito que essa abertura ao que o paciente nos apresenta em seu modo de ser e que deve ser compreendida pelo clínico é fundante em toda e qualquer clínica. Compreendo que no Acompanhamento Terapêutico, além de estarmos abertos ao modo de ser apresentado pelo paciente, precisamos também e sobretudo, estar abertos à potência interventiva do cotidiano. "O acompanhante funciona como suporte, que abre com sua presença a possibilidade e a esperança de que algo novo aconteça." (Mauer, S; Resnizky, S, 2004, p. 142). Mendonça (2017) aborda a questão do enquadre aberto na clínica do Acompanhamento Terapêutico, dizendo:

(...) um enquadre aberto sempre será mais complexo, multifacetado e polifônico que um enquadre fechado e essa complexidade expõe em maior medida o acompanhante terapêutico a ansiedades de tipo confusional...e uma forma defensiva de circunscrever a confusão pode ser operando com um enquadre fechado, ou seja: empregando um esquema de referência conhecido diante de uma situação desconhecida ou desconcertante. (p. 113)

Entendo que fazer frente a um enquadre aberto não é tarefa fácil ao acompanhante terapêutico. Recorrer a modelos já consagrados na clínica em vez de 
posicionar-se de maneira singular diante do novo, a meu ver, parece ser um grande desafio nessa prática clínica. Como bem aponta Mendonça (2017), o enquadre aberto apresenta uma complexidade por ser multifacetado, polifônico, e nesse momento, o acompanhante terapêutico podendo sentir-se angustiado, por vezes recorre a um esquema referencial já conhecido como forma de proteger-se dessa angústia. É comum nos depararmos em nossa prática clínica com interpretações de outros profissionais "não at's" do que poderia ser feito em determinadas situações de Acompanhamento Terapêutico; elas condizem muito mais com o que se faria em um enquadre fechado de consultório do que em um enquadre aberto de Acompanhamento Terapêutico. Há algo no Acompanhamento Terapêutico que está para além da dupla acompanhante-acompanhado e que diz respeito ao mistério do cotidiano.

Enquanto acompanhantes terapêuticos, penso que podemos propiciar, assim como uma ponte que possibilita a travessia, o encontro entre o paciente que acompanhamos (e que também nos acompanha) com o mundo afora, ainda que isso implique em todo o risco do que é viver. Muito se perde quando não aproveitamos o campo em sua magnitude, quando desperdiçamos a vida em movimento. Certas situações por si só são o próprio processo de devir para que o paciente possa descobrir-se em movimento. No meu entendimento, basta que estejamos atentos e abertos a isso, permitindo que o mais além possa acontecer durante os encontros.

\section{Parte II - Encontros}

Seguindo a proposta de apresentar os fundamentos do que concebo como primordial à clínica do Acompanhamento Terapêutico - e antes de adentrar os capítulos que tratam sobre a presença da família propriamente dita - apresentarei a compreensão do que entendo por encontro contando uma história que, a meu ver, carrega os fundamentos daquilo que considero ser encontro (na vida, na clínica, com o paciente ou com a sua família). 


\section{A história de Maria}

Estava em meu carro a caminho de um atendimento. Como de costume, parei em um dos semáforos do trajeto e, especialmente naquele dia, escutava um CD de Elis Regina que havia comprado dias antes. Assim que parei no semáforo, coloquei novamente para tocar uma música que tinha me emocionado muito, era uma versão de 1981 da música "Maria, Maria", Elis a cantava de forma mais lenta e visceral comparada à versão que estamos habituados a ouvir na rádio. Eu estava do lado esquerdo da avenida, próxima da calçada. À minha frente, havia uns cinco carros também parados. Enquanto esperava o sinal verde, avistei uma senhora que vinha andando na calçada (em minha direção) de cabeça baixa; arrastava no chão um saco grande que parecia estar bastante pesado. A sua roupa era surrada. Fazia muito calor, penso que a temperatura ultrapassava os trinta e cinco graus. Acompanhava cada passo da senhora. Fiquei muito sensibilizada por sua condição, pela roupa, pela idade, pelo calor que fazia enquanto ela arrastava sozinha aquele saco pesado. Enquanto andava, olhava para o chão. Por algum motivo fiquei hipnotizada, os meus olhos a seguiam, parecia sofrida. Senti compaixão. Enquanto isso acontecia, Elis cantava: "Maria, Maria, é um dom, uma certa magia, uma força que nos alerta...Uma mulher que merece viver e amar como outra qualquer do planeta. Maria, Maria, é o sol, é a cor, é o suor, é uma dose mais forte e lenta...de uma gente que ri quando deve chorar, que não vive apenas aguenta...". A senhora passou ao lado de meu carro e exatamente naquele minuto parou por um segundo e levantou a cabeça olhando para mim (que estava à sua esquerda); sorriu docemente e me mandou um beijo com uma de suas mãos. Abaixou novamente a cabeça e olhando para o chão foi embora arrastando o saco. Foi embora sem olhar para trás, continuou caminhando. Naquele momento eu nada entendi! Olhei para o lado para ver se havia mais alguém olhando para ela ou algo parecido, mas não havia mais ninguém além de mim. Continuei a acompanha-la, olhando-a pelo retrovisor. Algumas lágrimas começaram a cair, não contive a minha emoção. Eu nem havia me apresentado, ela nem sequer me conhecia... O sinal abriu. Queria fazer o retorno e ajuda-la de alguma maneira, pensei em dar todo o dinheiro que eu tinha, pensava: assim ela pode comprar alguma roupa, pode comer. Ao mesmo tempo, lembrava do paciente que me aguardava. Decidi também ir embora e foi somente no trajeto para o CAPS que eu me dei conta do 
tamanho de minha arrogância. Onde já se viu depois disso e de tudo o que ela me ofereceu eu ainda pensar em voltar para dar a ela o meu dinheiro para que se alimentasse? Alimentada sai eu! A emoção permaneceu até o momento em que eu cheguei ao CAPS, onde tentei me recompor.

Assim que entrei na sala, o paciente logo percebeu que eu havia chorado e me perguntou se eu estava bem. Eu disse que sim e resolvi compartilhar com ele o momento especial pelo qual havia passado. Contei toda a história. Ele além de olhar atento, sorria! Falei da música, cantei um trechinho e em seguida cantamos juntos. Ele era musicalmente sensível, durante os atendimentos sempre cantava ou sussurrava alguma canção. Foi então que ao contar para ele do meu desejo de voltar e dar àquela senhora todo o meu dinheiro que estava na minha bolsa, ele me interrompeu dizendo: "Ah, Camila! Não se trata de dinheiro...talvez fosse o caso de você ir até ela, abraça-la bem forte e agradecer por ela existir" (sic). Sorri e disse: "sim, sim! Mas só depois de um tempo é que eu fui perceber isso, e aí é que eu chorava ainda mais no caminho para cá..." (sic).

\section{Comunidade de destino}

Parece-me importante, após o relato de ambas histórias, trazer para a discussão a perspectiva de comunidade de destino apresentada por Safra (2004). Para esse autor, a relação clínica assentada na ética pressupõe conceber o paciente não apenas enquanto indivíduo em seu registro psíquico, mas também em seu registro ontológico:

Essa possibilidade não depende só de podermos observar o paciente, mas sim de estarmos com ele em comunidade de destino, para que possamos compreender (com - prehensor - chegar a) sua maneira de colocar-se e de significar sua existência. (Safra, p. 73, 2004).

No caso do cachorrinho Bidu, Marcos tanto pôde ser acompanhado, quanto acompanhante. Possibilitar que ele transitasse entre esses dois lugares, a meu ver, contempla o que Safra (2004) propõe enquanto perspectiva ética de comunidade de destino, uma vez que devolve ao paciente aspectos de si mesmo que podem ser vividos na relação com o acompanhante terapêutico. Marcos gostava de cuidar do 
outro, estar nessa posição Ihe devolvia algo profundo, de sentido existencial. Nas palavras de Safra (2004) "a verdade de si mesmo acontece e se revela somente pelo reflexo do rosto do outro." (p.43). A experiência de acompanhamento mútuo em uma situação de emergência nos aproximou. Nesse sentido, e no meu entendimento, a perspectiva de comunidade de destino carrega algo de resistência em relação aos modelos de atendimento clínico propostos em nossa área, nos quais a relação com o paciente é baseada em posições verticais em que apenas o saber do terapeuta é considerado, desconsiderando o saber do paciente.

Após o encontro com Maria, a questão que me surgiu também pode ser compreendida por esse viés: quem ali acompanhava? Eu a ela, ou ela a mim? Observava- a de longe e com muito carinho, um sentimento de empatia pelo provável calor que sentia naquele dia ensolarado (assim como qualquer outra pessoa que em seu lugar estaria, supostamente, sentindo o mesmo), pela provável pobreza revelada em suas roupas surradas, o provável cansaço pelo peso que carregava, afinal de contas já era uma senhora; e quando eu menos esperava, fui surpreendida com um gesto terno e sincero. Não nos conhecíamos, não sabíamos o nome uma da outra, não havíamos nos apresentado, mas algo ocorreu ali que me transformou, fui considerada a despeito de quem eu poderia ser ou estar representando naquele momento. Safra (2004) por meio da perspectiva de Sobórnost, que carrega o sentido de conciliar, nos auxilia a pensar situações da clínica (e por que não da vida?), ampliando o diálogo para além dos conflitos psíquicos apresentados pelos pacientes. Explica-nos o sentido do que pretende comunicar ao utilizar o conceito de comunidade de destino:

\footnotetext{
Uso o conceito de comunidade de destino não em seu registro social, o que significaria que só poderíamos dizer que estamos em comunidade ao compartilharmos as mesmas experiências sociais de alguém, tais como a condição operária, a condição de favelado etc. Na situação clínica, estamos em comunidade de destino com alguém quando nos posicionamos solidariamente com nosso paciente frente às grandes questões existenciais peculiares ao destino humano: a instabilidade, a necessidade do outro, a ignorância frente ao futuro, o sofrimento decorrente do viver, a incompletude da condição humana, a solidão essencial, a mortalidade, entre outras. Comunidade é nossa condição originária. Só nascemos em comunidade, somos em comunidade e morremos em comunidade. Desde sempre o ser humano é com o Outro. (p.73)
} 
No trecho destacado acima, o autor menciona que não usa o conceito em seu registro social, referindo-se à origem do conceito de comunidade de destino cunhado pela escritora e filósofa Simone Weil (1909-1943). Tal perspectiva foi apresentada por esta autora a partir de sua experiência como operária em uma fábrica da França. $\mathrm{Na}$ época, pode-se dizer que Weil realizou o que hoje compreendemos enquanto estudo de campo, pois pesquisou através de sua prática os conflitos e questões inerentes à classe operária de sua época.

Safra (2004), portanto, auxilia-nos a pensar sobre a precariedade da condição humana e a importância do sentimento de empatia. Para este autor, todas as pessoas carregam um saber sobre a condição humana, "fruto da angústia mesma" (Safra, 2004, p. 24). A situação originária com a qual cada um de nós se depara ao nascer, revela algo da existência humana. Segundo ele:

Não é um conhecimento que vem de uma aprendizagem ou pedagogia, mas sim do próprio fato de o ser humano ser lançado em meio à existência na busca das condições que possibilitem seu alojamento, mesmo que precário, no mundo com os outros. (Safra, 2004, p.24)

Salientar tal perspectiva, parece-me importante na clínica do Acompanhamento Terapêutico, seja com o paciente acompanhado ou com a sua família. O que eles (paciente e família) teriam a nos dizer sobre o seu sofrimento? O que eles teriam a nos comunicar sobre a condição humana? 


\section{Capítulo 4 - Família e clínica no Acompanhamento Terapêutico}

\subsection{Possibilidades de atendimento familiar na clínica do Acompanhamento Terapêutico}

$\mathrm{Na}$ prática clínica do Acompanhamento Terapêutico, diferentemente dos atendimentos realizados em consultório, a intermediação da família no início do processo é algo recorrente. Esse padrão de "chegada" revela algo de peculiar nesta clínica. Habitualmente, as famílias são as responsáveis pelas tomadas de decisão, tanto para iniciar o processo de Acompanhamento Terapêutico, quanto em outros setores da vida do paciente em que temos a sensação de que a pessoa atendida não existe, não têm nem ideias e nem desejos próprios, quase como um barco à deriva. É como se algo estivesse morto e a família, em muitos casos, sustentasse as condições necessárias à essa morte em vida. Na maioria dos casos percebemos que o entorno se tornou o principal responsável por guiar a vida do paciente, em detrimento, muitas vezes, do que lhe é próprio e singular.

$\mathrm{Na}$ entrevista inicial, as famílias tendem a se mostrar sobrecarregadas emocionalmente, colocando o paciente no lugar de "causador" dessa sobrecarga. Safra (2005) referindo-se ao momento da entrevista inicial, frisa a vulnerabilidade pela qual o paciente se encontra no momento em que se vê em uma situação que sugere tamanha intimidade, podendo este espaço ser sentido como um risco no início de todo processo terapêutico. Além disso, menciona que o modo como a pessoa chega, seja pela escolha da frase de abertura da conversa, seja pelo uso que a pessoa faz organizando o seu tempo e espaço, sempre tem em seu bojo uma comunicação, um gesto que veicula uma questão, apesar de parecer fala habitual.

No Acompanhamento Terapêutico observamos que o modo como a família chega nos dá indícios de sua dinâmica. De certo modo, até mesmo a maneira como o acompanhante terapêutico se sente nesse contato inicial com a família é fonte de revelação do caráter de sofrimento sentido pelo paciente.

Algumas famílias quando descobrem o Acompanhamento Terapêutico relatam sentir hesitação, e ao mesmo tempo, grande expectativa. Safra (2005) relata que em uma relação terapêutica inicial o paciente apresenta uma mistura de medo, esperança 
e expectativa mágica. Utilizamos esse modelo para ilustrar a situação terapêutica no Acompanhamento Terapêutico também do ponto de vista da família que vai ao encontro do acompanhante terapêutico na entrevista inicial, e não somente do paciente em relação ao terapeuta:

a) medo de que a experiência ruim já vivida aconteça novamente;

b) esperança de que haja o Encontro daquilo que ainda não foi vivido e nem sentido;

c) expectativa mágica de que em um passe de mágicas tudo se resolva.

Na entrevista inicial, algumas famílias costumam se apresentar sempre muito queixosas em relação ao paciente que será acompanhado, o

culpabilizando, inclusive e muitas vezes, por todo o sofrimento familiar. Em outro cenário, há famílias que não colocam o paciente nesse lugar de destaque, conseguindo aproveitar melhor o espaço de escuta oferecido pelo acompanhante terapêutico. Às vezes há um longo trabalho por parte do acompanhante terapêutico até descobrir juntamente com a família do acompanhado que o sofrimento familiar, por vezes, origina-se de questões outras que transcendem a problemática da queixa em relação ao paciente acompanhado. De todo modo, parece-me que, a dinâmica familiar apresentada por cada família no momento da entrevista inicial oferece alguns indícios de como o contato do acompanhante terapêutico com a família seguirá no decorrer do Acompanhamento Terapêutico.

Atualmente, temos duas possibilidades mais comuns de atendimento familiar nesta modalidade clínica. A primeira ocorre quando o atendimento familiar é realizado por um profissional da equipe de atendimento, não sendo o acompanhante terapêutico, mas sim outro profissional que se torna responsável pelo acolhimento e orientação dos familiares. Esse modelo de atendimento familiar existe normalmente em ambientes institucionais que trabalham com a modalidade clínica do Acompanhamento Terapêutico. A segunda possibilidade de atendimento familiar dáse com o próprio acompanhante terapêutico assumindo essa função junto à família. É importante diferenciar uma experiência clínica de outra, pois são atravessamentos que ocorrem de forma distinta na condução posterior do processo. 
Nos casos em que 0 acompanhante terapêutico realiza somente 0 Acompanhamento Terapêutico, há uma tendência para um lugar mais delimitado na relação com a família do acompanhado. A família cujo incômodo atravessa a relação com o acompanhante terapêutico e que tem a possibilidade de ser atendida por um segundo profissional, que não o acompanhante, supostamente sentir-se-ia mais à vontade para queixar-se das situações que a incomodam e que dizem respeito, inclusive, ao trabalho e/ou presença do acompanhante terapêutico. Já nos casos em que não há um profissional que realize o atendimento familiar, percebemos que a queixa da família sobre o acompanhante terapêutico continua a existir, porém transitando no decorrer do processo de maneira velada. Neste último caso, percebemos que a postura da família, por vezes, se torna hostil, e a presença do acompanhante terapêutico confere terreno fértil a sentimentos de raiva intensa e ao aparecimento de uma identificação projetiva que entra em cena de forma maciça. Cabe ressaltar que, muitas vezes, o funcionamento através de identificações projetivas por parte dos familiares em relação ao acompanhante terapêutico costuma ser proporcional ao sofrimento vivido por aquele núcleo familiar.

Em muitos acompanhamentos é comum a família sentir aspectos disparadores de persecutoriedade e insatisfação em relação ao acompanhante terapêutico. Se muitas famílias pudessem dizer claramente como se sentem, creio que diriam o seguinte: sinto-me invadida em minha própria casa pela a sua presença. A minha família sempre funcionou dessa forma e agora você sugere que as coisas mudem, isso me incomoda! Apesar de dizer a você que não vejo mudanças, a verdade é que eu vejo e é justamente isso que me assusta! Vamos acabar com tudo isso e voltar a ser como era antes...

O sentimento de ódio, a meu ver, e especialmente no âmbito da saúde mental, parece ser um fenômeno recorrente em casos que envolvem a família na clínica do Acompanhamento Terapêutico. Os acompanhantes terapêuticos, frequentemente, são odiados pela família do acompanhado a depender do tipo de configuração intrafamiliar estabelecida. Em contrapartida, sentimentos contratransferenciais por parte dos acompanhantes terapêuticos também envolvem o ódio em relação à família do acompanhado ${ }^{6}$.

\footnotetext{
${ }^{6}$ Esse assunto será melhor abordado no subcapítulo 4.7 desta dissertação
} 
Voltando às possibilidades de atendimento familiar na clínica do Acompanhamento Terapêutico, há também uma terceira configuração de trabalho com as famílias, que foi pensada a partir dos impasses vivenciados em minha prática clínica. Dependendo do sofrimento psíquico familiar, há o estabelecimento de um contrato com a família do acompanhado que prevê que o atendimento familiar seja realizado por um segundo profissional. Nesse caso, não seria o acompanhante terapêutico o responsável pelas reuniões com a família do paciente. Também não haveria um encaminhamento à terapia familiar (apesar de isso ocorrer, caso seja necessário), mas sim um espaço de escuta que proporcione o acolhimento necessário à família, o qual oferece a possibilidade de discutir o trabalho realizado pelo acompanhante terapêutico, assim como um espaço necessário de orientação familiar. Nesse sentido, o acompanhante terapêutico mantém-se em contato com a família do acompanhado somente durante os acompanhamentos. Esse modelo foi pensado a partir dos modelos institucionais que funcionam com esta mesma configuração, nas quais o trabalho de acolhimento e orientação familiar é realizado por um profissional distinto do acompanhante terapêutico responsável pelo paciente.

Considero importante ressaltar o trabalho integrado realizado em equipe no Acompanhamento Terapêutico, assim como a familiaridade e simpatia com a abordagem clínica vivida tanto em análise pessoal, quanto em supervisão. Desta forma, torna-se possível construir uma parceria com profissionais que inicialmente trabalham de modo autônomo, sendo o fator primordial o compartilhamento da visão de ser humano que vincularia esses profissionais em torno da pessoa acompanhada. A esse respeito e indo mais além, Barretto (1998) menciona, inclusive, a importância de se ter bem integrada a abordagem teórica à pessoa do at:

\footnotetext{
Em relação ao referencial teórico adotado pelo at/analista, existem aspectos importantes dessa função. Se os referenciais teóricos estão integrados ao próprio ser do terapeuta e à sua personalidade, haverá um favorecimento do holding. Por outro lado, se os referenciais não estão bem integrados, ou ainda, adotamos diferentes referenciais que são contraditórios entre si, poderse-á colocar o paciente em confusão, o que dificultará e/ou romperá o vínculo de confiança. Caso isto ocorra a função de holding estará comprometida. (p.63)
}

No campo do Acompanhamento Terapêutico é frequente escutarmos sobre a importância de os acompanhantes terapêuticos estarem inseridos em uma equipe, dada à complexidade de seu trabalho e sobrecarga emocional a qual estão 
submetidos, além de manter as funções bem discriminadas perante o paciente e a família. Muito embora compartilhe desse pensamento em relação à complexidade e sobrecarga emocional vividas pelo acompanhante terapêutico, penso ser possível realizar um bom trabalho sem que o acompanhante terapêutico esteja inserido em uma equipe institucional ou de at's. Partindo de minha experiência, julgo que é possível o trabalho configurado a partir de parcerias profissionais, numa equipe autônoma, isto é, que não esteja vinculada necessariamente a uma instituição.

Em casos nos quais seja possível avaliar já na primeira entrevista o sofrimento familiar, combina-se com a família que juntamente com a elaboração do projeto terapêutico destinado ao paciente, haverá um segundo profissional responsável pelos atendimentos familiares. Nesse terceiro modelo de atendimento, a participação do acompanhante terapêutico nas reuniões familiares é avaliada em sua pertinência ou não, a depender de cada caso. Nessa proposta de atendimento, o acompanhante terapêutico se resguardaria de identificações projetivas excessivas, (característica recorrente nos casos mais difíceis) e concomitantemente ofereceria à família do acompanhado o cuidado necessário para o prosseguimento do trabalho. Essa configuração de atendimento foi pensada a partir das vicissitudes encontradas em meu percurso profissional como acompanhante terapêutica. Em dado momento do processo, e em especial com famílias em grave estado de sofrimento psíquico, a família do acompanhado pode vir a estabelecer uma transferência negativa com o acompanhante terapêutico. Esse modelo resguarda, de alguma forma, o trabalho como um todo, oferecendo espaço de escuta e cuidado aos familiares, ao mesmo tempo em que protege o vínculo entre acompanhante terapêutico/família e acompanhante terapêutico/paciente. Quando as identificações projetivas são excessivas, sentimos que o trabalho paralisa e logo em seguida costuma encerrar-se a pedido dos familiares. Sendo assim, vislumbrei a partir desta outra vertente de trabalho, uma possibilidade de trabalho outra, mais integrada e em consonância com o que entendo ser terapêutico, quando há famílias que se encontram com um alto grau de sofrimento psíquico e que demandam cuidado.

Em minha experiência percebi que quando encontramos na família alguém que tenha, minimamente, aspectos do self mais integrados, a realização do atendimento familiar oferecido pelo próprio acompanhante terapêutico torna-se mais viável. O fato de existir alguém, na família do paciente, que tenha aspectos mais saudáveis 
preservados, interfere, inclusive, no que é observado em termos de saúde psíquica apresentada pelo próprio paciente.

Recordo-me de uma jovem com transtorno neurológico que apresentava um leve quadro depressivo. Nos atendimentos familiares era evidente a desorganização interna da mãe, pois ela discordava de todas as sugestões que a acompanhante terapêutica fazia, e não tinha abertura para olhar a situação por outro ângulo, sempre acusando a paciente de não fazer o que ela achava que deveria ser feito. O pai, durante os atendimentos aderia à lógica da mãe, concordando com tudo o que ela dizia, porém quando a mesma deixou de comparecer aos atendimentos em consultório, o pai mostrou-se compreensivo ao sofrimento da filha, chegando a verbalizar, inclusive, o quanto percebia que toda a família estava adoecida e não somente a filha. Nestes casos, quando o acompanhante terapêutico encontra abertura por parte de um dos pais, o trabalho tende a evoluir em relação ao desenvolvimento psíquico do paciente. No caso ilustrado, por exemplo, o pai sentia-se visto em sua dor pela acompanhante terapêutica, tornando possível que o encontro terapêutico acontecesse, inclusive, para além das questões apresentadas pela filha.

A seguir, para que se tenha uma ideia mais clara das possibilidades de atendimento familiar na clínica do Acompanhamento Terapêutico, foram sistematizadas, a partir do que tive contato em minha experiência profissional, três possibilidades de cuidado familiar mencionadas anteriormente. Essas possibilidades certamente não se esgotam, podendo haver outras configurações de trabalho com a família nesta modalidade clínica:

a) institucional: acompanhante terapêutico inserido em uma equipe institucional de atendimento na qual já exista o profissional específico responsável pelos atendimentos familiares. Essa função, normalmente, é desempenhada pelo psicólogo, psicanalista, terapeuta ocupacional ou assistente social da instituição. As reuniões familiares ocorrem com frequência semanal, mensal e/ou a depender da demanda de cada caso;

b) atendimento familiar/acompanhante terapêutico: neste caso o acompanhante terapêutico não está inserido em uma equipe institucional, mas pode realizar os encontros com a família do acompanhado. O seu 
trabalho acontece em parceria com outros profissionais autônomos envolvidos no caso, tais como psicólogos, psiquiatras, psicanalistas, entre outros. Sendo assim, tanto o acompanhante terapêutico quanto o outro profissional envolvido no caso realizam encontros periódicos com a família. Este modo de trabalho, a meu ver, seria indicado para o atendimento à famílias que estejam em um estado de sofrimento psíquico significativo, porém não de caráter psicótico. Esse modelo é comumente utilizado em casos de Acompanhamento Terapêutico no âmbito judiciário, os quais envolvem disputa de guarda, tornando imprescindível que o acompanhante terapêutico realize encontros periódicos com as partes envolvidas no litígio;

c) atendimento Familiar/ Parceria Profissional: neste caso o acompanhante terapêutico também não está inserido em uma equipe institucional, mas estabelece relação de parceria de trabalho com outro profissional autônomo, cuja responsabilidade é a realização dos atendimentos familiares. $O$ acompanhante terapêutico e profissional escolhido para esse trabalho realizam discussões clínicas sobre o caso e conduzem, conjuntamente, o projeto terapêutico singular do paciente. Esta modalidade de trabalho é indicada para atendimento às famílias com sofrimento psíquico de grave à moderado.

Com a grande oferta de cursos de formação em Acompanhamento Terapêutico, percebemos que muitos profissionais, posteriormente ao término do curso, já iniciam a prática clínica de atendimento não estando, necessariamente, inseridos em uma equipe institucional. Esse modo de trabalho tornou-se uma idiossincrasia do Acompanhamento Terapêutico no Brasil, pois em outros países há o reconhecimento da necessidade de se ter uma equipe (institucional) de atendimento para a realização do que se entende como um bom processo de Acompanhamento Terapêutico. Para alguns autores da Argentina (Dragotto y Frank, 2012; Machado, Benitez, Corro y Moran, 2015), o acompanhante terapêutico teria apenas um papel auxiliar dentro da equipe de atendimento, devendo estar sempre subordinado às orientações dadas dentro do próprio grupo, o que implicaria, a nosso ver, em menos autonomia do acompanhante terapêutico na condução do caso. Nos casos em que o acompanhante 
terapêutico não se encontra vinculado a alguma equipe institucional, recomenda-se, a depender da necessidade, que qualquer mudança de estratégia e/ou intervenção também seja discutida em supervisão. Procuro mostrar na presente dissertação que o trabalho do acompanhante terapêutico em parceria com outros profissionais autônomos não seria menos cuidadoso apenas por não estar instituído. Compartilho da ideia de Safra (2006), quando diz que "na história do Acompanhamento Terapêutico observa-se que esta modalidade de intervenção clínica foi frequentemente tratada como uma abordagem meramente auxiliar, muitas vezes até mesmo desvalorizada. “(p.2). O Acompanhamento Terapêutico, a meu ver, torna-se fundamental em alguns casos, pois é capaz de devolver ao paciente a dignidade perdida e às vezes até mesmo nunca tida e sentida. Creio que quando falamos de equipe, não podemos reduzi-la apenas à institucional, é preciso reconhecer a legitimidade do trabalho também em outros modelos de organização de trabalho em torno da pessoa atendida. Segundo Frank (2013):

A equipe ou o terapeuta é quem introduz o acompanhante terapêutico no seio do tratamento. Dentro de uma equipe de trabalho se multiplicam os olhares, as escutas e as situações nas quais o tratamento está presente para o paciente, permitindo a escuta do singular para o aparecimento do singular. Sem esta direção, sem o trabalho em equipe, o acompanhante corre o risco de deixar de ser um dispositivo terapêutico. (p.1)

Essa compreensão da figura do acompanhante terapêutico como alguém que deve estar inserido em uma equipe, também pode ser pensado como modelo no trabalho do acompanhante que delineia os seus procedimentos com uma equipe de profissionais não conectados anteriormente por uma relação de trabalho, uma vez que há a possibilidade de serem discutidas em supervisão as situações vividas com o paciente. No espaço de supervisão, assim como no contato com o profissional que encaminhou o paciente, observa-se também essa possibilidade de multiplicação de olhares e de escutas rumo ao singular.

Em minha experiência como acompanhante terapêutica pude perceber que o papel do acompanhante terapêutico, em muitos casos, tornava-se central e gerava importantes transformações. Há certo tempo, um colega psicanalista que atendia em psicoterapia uma moça com quadro de Epilepsia, relatou o quanto o trabalho em consultório não evoluía com essa paciente. Explicando a ele sobre o trabalho que era realizado em Acompanhamento Terapêutico, se interessou por essa modalidade de 
atendimento e pediu à família que me procurasse para iniciar o atendimento. Antes de o acompanhamento começar, o psicólogo responsável pelo atendimento em consultório havia me contado que a paciente (Giovana) mais faltava às sessões do que comparecia, e quando comparecia chegava sempre muito atrasada. Com o início do acompanhamento a paciente começou a faltar em quase todas as sessões de psicoterapia, até que não mais apareceu e foi decidido pelo terapeuta, pela paciente e pelo próprio acompanhante terapêutico transferir o seu atendimento apenas para o Acompanhamento Terapêutico. A paciente fazia um uso fecundo desta modalidade clínica, sempre pedia mais horas de atendimento. Com o tempo, foi sendo possível avaliar que não se tratava de conversar sobre o não vivido, mas sim de viver em primeiro lugar experiências significativas para só depois poder pensar sobre elas. Giovana estava com vinte e oito anos de idade quando iniciou os acompanhamentos, tinha um quadro grave de Epilepsia que, somado ao fato de os pais terem uma preocupação excessiva com ela, fazia com que não conseguisse sair de casa. Passou a vida sem ter tido quase nenhum convívio social. Ter que ir à terapia para falar da dor de ser invisível, do preconceito sentido por ela dentro de sua própria família, além do estigma de ser vista pelos outros como epilética e incapaz, era algo que a machucava, transformando a terapia em algo sem sentido. A dor sentida ao cair todos os dias ao chão já era para ela algo da ordem do insuportável, novas experiências em sua vida precisavam ser inauguradas. Comentar sobre o quadro de Epilepsia com o terapeuta e narrar as situações pelas quais passava a deixava ainda mais deprimida, e não a ajudava em muita coisa.

Ao longo do acompanhamento, sempre que os encontros estavam próximos de acabar ela dizia não querer voltar novamente à prisão, referindo-se à sua própria casa. No caso desta paciente, a terapia não conseguia cumprir a função a qual se propunha, o processo em si chegava a ser até mesmo torturante para ela. Com o acompanhamento, muitas transformações ocorreram, tanto em nível familiar, como em termos de rotina, expressão de sentimentos; medos e anseios puderam ser acolhidos e trabalhados a partir de situações vivenciadas durante os atendimentos. Neste caso, portanto, o acompanhamento terapêutico não foi auxiliar, foi central. Possibilitou que a paciente se sentisse viva, começasse a se relacionar, e a partir dessa vivência começasse a ter referências externas para se reposicionar perante os pais, perante os colegas, perante a vida. Esse exemplo nos remete exatamente à 
origem do Acompanhamento Terapêutico, como alternativa, e por vezes única possibilidade de intervir com pacientes que não conseguem encontrar sentido nos atendimentos convencionais em consultório.

Após poucos meses de acompanhamento fomos até um local para pedir informações sobre determinado curso que a paciente gostaria de fazer. Ela não conseguia verbalizar, não sabia as suas informações pessoais, tais como endereço, telefone, CPF, absolutamente nada, é como se estivesse chegando há pouco àquele mundo, e era exatamente isso, antes disso ela não existia. Na volta para casa comentou que estava se sentindo péssima, pois não conseguia nem prestar informações básicas a uma atendente. Naquele dia, teve uma crise durante o acompanhamento, pois toda vez que ficava muito triste ou envergonhada em alguma situação a crise aparecia como uma descarga de toda a emoção contida, a crise naquele dia era o corpo que chorava e esbravejava.

Com o tempo foi importante poder reunir os pais para explicar como o acompanhamento estava caminhando e a importância de algumas intervenções que tinham sido realizadas, bem como conversar sobre aspectos práticos e financeiros, já que essas decisões ainda não podiam ser definidas exclusivamente pela paciente por conta de sua dependência financeira. A proximidade do acompanhante com os pais foi muito importante e intervenções necessárias foram realizadas tanto com a família quanto com a acompanhada. Cabe ressaltar que, neste caso, a família não tinha um funcionamento psicótico, o que possibilitou que o trabalho em conjunto acontecesse.

Em situações nas quais o acompanhante terapêutico é quem realiza o atendimento familiar, ao mesmo tempo em que é o responsável pelo projeto terapêutico do paciente, notamos que a sua função se torna mais complexa dada a proximidade com os membros da família na casa do paciente, assim como nos encontros realizados em consultório.

Podemos dizer que o acompanhante terapêutico que trabalha com essa perspectiva, frequentemente sente a intensa demanda advinda desse tipo de situação. Em minha experiência clínica como acompanhante terapêutica senti por muitas vezes uma sobrecarga contratransferencial intensa provinda da relação com famílias adoecidas. As famílias me procuravam incessantemente, telefonavam, enviavam emails, uma delas, inclusive, mandava cartas fazendo perguntas e justificando comportamentos que tinha em relação ao paciente. Compreendo que o olhar oferecido 
a essas famílias propiciava esse tipo de comunicação, mas com o tempo entendi que era importante colocar certos limites para preservar minha sanidade mental, afinal de contas o conteúdo dessas comunicações por parte das famílias envolvia sempre muitas exigências, cobranças, queixas em demasia, o que me fez concluir que talvez o espaço mais apropriado para tratar dessas questões fosse mesmo o consultório. Algumas não aceitavam ir até o consultório alegando que seria uma despesa a mais, eu fazia concessões, mas com o tempo a situação tornava-se insustentável.

É importante sublinhar que o acompanhante terapêutico transita por muitos lugares no seio familiar, por vezes é colocado em um lugar de adversário, de invasor, daquele que cria obstáculos. Em outros momentos, como parceiro, socorrista, testemunha e consolador. Vivi todos esses registros nas relações com as famílias de cada paciente, com alguns os lugares pareciam se cristalizar e por mais que eu me esforçasse para sair deles, o esforço era em vão. Em outros momentos, sentia como que se transitasse em todos ao mesmo tempo em apenas uma família, e por muitas vezes sentia tudo isso em somente um encontro, muitas vezes o esgotamento emocional era imenso.

Podemos dizer que o trabalho realizado pelo acompanhante terapêutico é intrusivo por natureza. Adentramos os lares das pessoas, testemunhamos muitas vezes tudo o que a família por vezes quer esconder, inclusive e em muitos casos, de si mesma.

Outro ponto que me parece importante discutir diz respeito à decisão de atender a família no ambiente domiciliar ou em realizar os encontros no consultório. O setting que se oferece à família no acompanhamento terapêutico não muda porque a encontramos no consultório. Podemos encontrar o paciente de acompanhamento em sua casa e continuar ofertando a ele o trabalho proposto. Podemos encontrar o paciente de consultório em um café e continuar a realizar psicoterapia. A compreensão do que caracteriza um setting está para além das dimensões físicas do espaço, ultrapassa e transcende esse olhar.

O trabalho com a família em consultório é um assunto discutido frequentemente no campo do Acompanhamento Terapêutico. Entendo que, encontrar a família em consultório não configura uma desvirtuação do setting, ou seja, não é porque atendemos a família em consultório que estamos fazendo psicoterapia. O enquadre deve ser bem estabelecido no início do processo, esclarecendo que os encontros têm 
por objetivo a discussão do projeto terapêutico destinado ao paciente. O que também não impede de acolher questões pessoais de um dos pais e/ou familiares. A ideia do espaço oferecido à família não é de um lugar engessado, ao contrário, ele pode e deve ser flexível, considerando as especificidades de cada caso. Recordo de um caso no qual a mãe sempre comparecia aos atendimentos mensais em consultório. Todas as vezes eu pontuava a importância de que ela pudesse buscar um atendimento individual psicoterápico para auxilia-la nos conflitos com a filha, assim como em suas questões pessoais. Certa vez, ao perguntar se ela havia conseguido iniciar o processo de psicoterapia individual, disse-me: "Mas eu já faço!". Perguntei: “Como assim?” Ela sorriu e disse: "Aqui, com você!" (sic). Logo em seguida reforcei a importância de que ela procurasse um espaço que acolhesse essa demanda, uma vez que os nossos encontros não tinham esse objetivo. Muito embora os encontros não tivessem a intenção de acolher essa demanda, havia uma preocupação de minha parte em acolher as questões trazidas por ela e amarra-las aos conflitos vivenciados na relação com a filha. Penso que essa é uma forma possível de trabalho que viabiliza um vínculo importante com a família do acompanhado.

Considero importante abordar a questão do setting na clínica do Acompanhamento Terapêutico, tanto no que concerne à família, quanto ao próprio acompanhado. Em sua origem, tal modalidade clínica pressupunha saídas com pacientes internados que não conseguiam aderir ao modelo clássico de atendimento em consultório, o trabalho de re-socialização foi sendo possível somente a partir de intervenções no cotidiano dessas pessoas (Mauer, S. K ; Resnizky, S, 1987). Atualmente, percebemos que a realidade do Acompanhamento Terapêutico ganhou novos contornos. Em certos casos, o que precisamos abordar no encontro com o paciente são as necessidades que emergem em cada situação vivida durante os atendimentos. Assim, por exemplo, em seu lar o paciente pode nos solicitar enquanto uma presença de apoio para as suas ações cotidianas, a fim de que elas possam vir a adquirir algum sentido, tornando-se experiência compartilhada, uma vez que anteriormente eram atividades desejadas, mas ainda sem sentido inter-humano. Em muitas situações, o paciente nos solicita experiência de grande intimidade em seu lar, um auxílio que viabilize atividades do cotidiano que antes não eram possíveis de serem realizadas quando o paciente se encontrava sozinho, porém com a presença 
do acompanhante passam a ganhar estatuto alcançando a possibilidade de realização.

Sendo assim, olhar o setting terapêutico remetido estritamente ao ambiente físico seria reduzir a amplitude do campo, o que constituiria grande equívoco. $A$ definição de setting, neste contexto, se relaciona mais ao posicionamento que se tem no encontro do que ao lugar físico onde ele acontece.

Cabe ressaltar também que, a escolha em atender a família no consultório, em determinado momento, não exclui as intervenções e convivência necessárias que ocorrem na casa do paciente durante os atendimentos. Testemunhamos muitas das vezes grande desorganização no ambiente de origem da pessoa acompanhada, o que nos leva a necessitar de um espaço minimamente preservado para tratar com a família questões que dizem respeito ao processo de AT. Essa proximidade auxilia, inclusive, na construção da aliança terapêutica com os familiares e revela que o olhar do acompanhante também está direcionado ao sofrimento deles. 


\title{
4.2. Família e a importância do gesto na clínica do AT: um encontro entre gerações
}

\author{
$O$ que é resgatar o gesto? É resgatar a \\ possibilidade originária do ser humano de \\ transcender a experiência imediata para poder \\ atravessa-la. (Safra, 2006b, p. 41)
}

Considerando a clínica do Acompanhamento Terapêutico como a clínica do cotidiano como bem aponta Mendonça (2017), um fator importante a ser destacado é a diversidade de interações que ocorrem entre paciente-cotidiano-acompanhante a cada encontro. Essas interações costumam ocorrer entreolhares, risos, palavras, silêncios, gestos...

Destaco a importância do gesto na clínica do Acompanhamento Terapêutico por considerar que muitas vezes em nosso meio ele não é visto como intervenção. Porto e Sereno (1991) no primeiro livro brasileiro publicado sobre Acompanhamento Terapêutico já discorriam acerca da influência de algumas ações enquanto possibilidade interventiva:

(...) um abraço tem valor de uma intervenção, por exemplo, quando assim o acompanhante tira o paciente da luta inútil com um poste que não sai do seu régio caminho, imaginando no paciente uma criança desesperada, precisando da presença forte e corpórea de um adulto. (p.29)

Pensar essas intervenções para além da relação entre acompanhante/acompanhado e introduzir a família também em direção a esse vértice parece ser, a meu ver, uma tarefa fundamental a todos nós acompanhantes terapêuticos que enxergamos em cada sintoma da família a expressão de um sofrimento. Mendonça (2017) nos auxilia a pensar a clínica do Acompanhamento Terapêutico a partir dela mesma e não a partir de "enquadres fechados". Nesta perspectiva, sistematiza três eixos fundamentais do que denominou "Ação Interpretativa": 1) ação concreta; 2) ação verbal e 3) ação passiva. A ação verbal refere-se às intervenções mediadas pelas palavras durante o encontro com o paciente e a ação passiva à possibilidade de o acompanhante terapêutico se silenciar em momentos específicos como forma de intervir em determinada questão que é significativa ao paciente. 
A ação que me interessa destacar é a ação concreta, que segundo o autor, é uma ação que fala por si só pois veicula uma mensagem. Em determinado AT, a criança angustiava-se sempre que a acompanhante terapêutica sinaliza ir embora, havia uma angústia de separação característica nesse caso. Os pais da criança eram separados e durante os atendimentos ela perguntava à acompanhante quantos dias faltavam para ver cada um de seus pais. Confusa, contava em seus dedinhos os dias, mas logo em seguida esquecia-se perguntando novamente. A acompanhante terapêutica, então, decidiu dar de presente à criança um calendário de parede. $\mathrm{A}$ criança, assim que recebeu o presente decidiu colocar coraçõezinhos de cores diferentes que representavam cada uma das pessoas de quem gostava (incluindo a acompanhante terapêutica) e que iria encontrar no decorrer daquela semana. Dessa forma, quando a paciente estava em dúvida sobre quantos dias faltavam para ver cada uma das pessoas, olhava para os corações e contava. A intervenção não se deu pela palavra, mas sim pela ação, oferecendo à criança o contorno necessário à sua angústia. Mendonça (2017) alude à obra de Sechehaye (1947), psicanalista suíça, ao recordar as ações concretas realizadas por ela no trabalho com uma paciente que necessitava de intervenções que estivessem em consonância com o seu estado psíquico mais regredido:

Há situações em que não há um objeto concreto, mas sim a ação concreta de, por exemplo, conter e envolver com cobertores uma paciente (...). Em poucos minutos a paciente sentiu-se melhor e deixou de morder o braço, em sua busca desesperada de algo concreto-sensorial que delimitasse sua dor abstrato-psicológica. (p.198)

Em outro acompanhamento, um menino de cinco anos brincava de se jogar da cama no chão, pedia para que a acompanhante, no momento do pulo, o segurasse. A acompanhante, em vez de dizer que o seguraria, abria os braços de tal forma que desse segurança à criança de que seria acolhida. A criança questionava a acompanhante se ela a seguraria, e como resposta a acompanhante abria os braços e a criança pulava; o movimento, então, passou a ser esse: a criança pulava, a acompanhante segurava, e assim por diante repetidas vezes. Isso se deu no início dos acompanhamentos, o paciente precisava saber se poderia ou não confiar na acompanhante (se jogar nessa relação e ser segurada pela acompanhante), além desse tema do pular estar atrelado a uma questão bem importante em sua biografia. 
Esses exemplos, parecem ilustrar o que Mendonça (2017) descreve enquanto "ação concreta" no Acompanhamento Terapêutico. Estender esse conceito ao trabalho com as famílias na clínica do Acompanhamento Terapêutico, parece-me algo importante por se tratar de uma possibilidade, a meu ver, fecunda de intervenção. Assim como o contato do acompanhante com o paciente, o contato com a família também ocorre no cotidiano e justamente por esse motivo é que entendo ser necessário falar do gesto, uma vez que as ações constituem, primordialmente, o cotidiano das pessoas.

\section{Família e gesto}

A experiência mostra que os lugares pelos quais a família transita no Acompanhamento Terapêutico, assim como os lugares pelos quais o acompanhante terapêutico transita em contato com a família durante todo o processo, evidenciam os desafios enfrentados pelos acompanhantes terapêuticos nessa modalidade clínica. A escolha do verbo "transitar" (por lugares) em vez de "ocupar" (lugares) refere-se à compreensão de que "transitar" sugere a ideia de algo fluido, enquanto que o verbo "ocupar" alude a algo fixo. Inúmeras são as possibilidades de transitar pela família do acompanhado no Acompanhamento Terapêutico e em certa medida, os envolvidos na trama familiar dão indícios de onde o acompanhante deve ou não transitar, os limites da sua atuação, o potencial das intervenções, os momentos de recuo, os encontros possíveis, os desencontros inevitáveis.

Tendo em vista as diversas possibilidades junto à família e a importância do gesto como fecunda intervenção também no contato com esta e não somente com o paciente, abaixo será apresentada uma narrativa literária de caso clínico que, a meu ver, carrega os fundamentos do que entendo favorecer o encontro entre acompanhante terapêutico e família do acompanhado. Na primeira parte, iremos salientar os momentos mais significativos dos acompanhamentos de uma menina de sete anos de idade que foi atendida em ambiente domiciliar, bem como as intervenções realizadas pela acompanhante terapêutica que favoreceram o encontro entre os membros da família através não somente da palavra, mas principalmente e sobretudo, do gesto. Na segunda parte, trataremos sobre o sentido das intervenções. 


\section{Parte I}

O cenário familiar quando do início dos atendimentos envolvia a separação dos pais, a completar quase dois anos. O pai de Rebeca (paciente) constituiu nova família e foi morar em outra casa. Já a sua mãe, após a separação, permaneceu na mesma casa e pediu à irmã mais velha (tia das crianças) que morasse com eles, pois precisava de ajuda nos cuidados com a casa e com as crianças enquanto trabalhava fora.

Os atendimentos tinham como objetivo auxiliar a criança a se organizar em determinadas tarefas. Rebeca apresentava dificuldades para almoçar antes de ir à escola, quase sempre se atrasava para a chegada da perua escolar e não gostava de realizar as lições de casa. Os acompanhamentos se organizavam da seguinte forma: a acompanhante terapêutica chegava e a pedido da criança brincavam durante um curto espaço de tempo antes de Rebeca tomar banho, trocar de roupa e almoçar. A criança também era atendida em outros dias da semana por um profissional que a auxiliava nas lições de casa. Todo o acompanhar da rotina desta criança evidenciava a necessidade clara de uma presença materna e/ou paterna que a auxiliasse nas tarefas mais simples do cotidiano e com as quais apresentava dificuldades significativas.

Durante os atendimentos estavam sempre presentes a tia e o irmão mais novo da criança. A relação com o irmão era marcada por muito ciúme e ódio. Durante os encontros, o irmão de Rebeca sempre pedia para participar das brincadeiras, Rebeca era incisiva e dizia que não. Referia-se sempre ao irmão pequeno como intruso quando este queria participar das brincadeiras entre a acompanhante terapêutica e ela, tratava-o com desdém e sentia-se insegura com qualquer aproximação entre seu irmão e a acompanhante, dizia a ela:" ele é bonitinho por fora, mas é feio por dentro. Na verdade, ele é feio por fora e por dentro também" (sic). Rebeca foi uma menina roubada em suas possibilidades de continuidade nas relações mais íntimas e por isso se sentia ameaçada pela presença de qualquer pessoa que pudesse separá-la novamente de quem gostava, pois com a vinda do irmãozinho mais novo a atenção de sua família e, principalmente, de sua mãe, a quem Rebeca era mais apegada, voltaram-se toda para o seu irmão mais novo. Além disso, o pai também havia 
constituído nova família e aguardava um novo filho, fazendo com que Rebeca se sentisse ainda mais abandonada.

A relação que Rebeca tinha com a tia mais velha era conturbada, apesar de tentar se aproximar da sobrinha, ela a tratava com indiferença e quando não, a tratava de forma agressiva. Em muitos momentos a acompanhante terapêutica presenciou a tia se dirigindo à sobrinha e ela a ignorando ou destratando-a. A tia, que já era uma senhora, era quem fazia a comida antes das crianças irem à escola, e Rebeca sempre reclamava de como ela a preparava, ou porque não acertava o "ponto". Com frequência a tia desabafava com a acompanhante terapêutica dizendo que a sobrinha era muito mal-educada. Dizia também que as crianças de hoje em dia tinham de tudo e que por isso já não respeitavam os mais velhos. O irmão mais novo de Rebeca era muito apegado a essa tia, ela dizia que ele sim era carinhoso, mas que Rebeca não a deixava se aproximar dela.

\section{Percepção da acompanhante terapêutica em relação à tia da criança:}

Dona Maria tinha uma aparência de quem havia sofrido muito na vida, era uma senhora muito simples, sem jeito às vezes para falar, não tinha um dente. A família estava em ascensão econômica e morava em um condomínio de alto padrão, a sobrinha estudava em um estabelecimento escolar com pessoas que tinham um poder aquisitivo elevado, no entanto, a origem da família era pobre.

Um dia Rebeca começou a gritar com a tia que não tinha trazido o suco do sabor que ela gostava, a acompanhante terapêutica conversou dizendo que entendia o quanto ela ficava brava quando percebia que não era considerada em suas necessidades pelas pessoas (mesma queixa de quando reclamava da carne que não estava no ponto de que gostava), mas que apesar de entender que não se sentia vista, Dona Maria parecia, a seu ver, fazer o melhor que podia por ela. Ela respondeu à acompanhante que não gostava da tia e que além do mais ela fedia. Tal fala da criança era recorrente e às vezes dizia isso na frente de Dona Maria e para ofendê-la. Cabe mencionar, que a acompanhante nunca sentiu nenhum odor ruim no contato com a tia. 
A relação de sua mãe com a tia não era das melhores. Rebeca era a filha mais identificada com a mãe, principalmente após a separação dos pais, a dor da mãe era também a dela, ambas se sentiram abandonadas.

A acompanhante terapêutica buscava, ao mesmo tempo em que reconhecia a dor da criança, ter gestos de agradecimento e afetuosidade para com Dona Maria, sempre que esta se direcionava a ela. A criança observava atentamente esse movimento por parte da acompanhante. Quando a tia se queixava da sobrinha, a acompanhante ficava em silêncio procurando não intervir, assim também era quando Rebeca tratava sua tia de maneira hostil. A acompanhante procurava nessas situações se comunicar com a tia pelo olhar, já que não podia desconsiderar a dor da criança, mas também se sensibilizava com a condição que Dona Maria se encontrava. Foi o gesto que a acompanhante encontrou para dar um lugar, através do olhar, à dor daquela senhora.

\section{$1^{\mathrm{a}}$ intervenção: intensificando o registro empático}

Certo dia, durante o encontro, Rebeca foi ao banheiro e a acompanhante aproveitou para ir ao carro buscar um brinquedo que estava faltando. Quando retornou, a criança estava aos prantos achando que ela tinha ido embora. Nesse momento Dona Maria procurou acalmá-la e as três (tia, sobrinha e acompanhante) ficaram ali juntas no sofá.

A acompanhante percebendo que seria um momento oportuno tentou conversar de modo que todos pudessem interagir. Dona Maria começou a contar sobre a sua infância e a acompanhante entendeu que seria importante continuar ali para que a criança pudesse conhecer melhor a história de vida da tia, uma vez que a família parecia estar tão desenraizada de sua origem. Enquanto Dona Maria contava sobre a infância pobre e a falta de atenção dos pais, a acompanhante perguntou à criança se ela conhecia a história de vida da tia mais velha, ao que obviamente, respondeu que não. O olhar de todos se cruzava.

Mais adiante, Dona Maria dizia que não entendia as crianças da época atual, pois tinham de tudo e não davam valor a nada. A acompanhante vislumbrou mais uma oportunidade de encontro entre tia e sobrinha, explicando à Dona Maria que ainda que parecesse que sua sobrinha tinha tudo, no fundo ela sentia que não tinha nada, que 
sentia muita falta da mãe que trabalhava fora e do pai que havia saído de casa e formado outra família. Dona Maria nesse momento disse que falava mesmo para a filha ficar mais tempo com os filhos, mas que não adiantava muito. Tia e sobrinha se olharam mais uma vez. O olhar entre elas já não era mais o mesmo. A acompanhante decidiu intervir dizendo à criança que gostou muito de saber mais sobre a vida de Dona Maria, e que ao que parecia a tia no fundo sabia bem o que ela sentia, porque ela também vivera em sua história muita fome, fome de afeto, fome de amor, assim como ela que também sentia fome de ter o pai e a mãe sempre por perto.

\section{2ª intervenção: a dignidade perdida e sua devolução pelo gesto}

Certa vez, a acompanhante terapêutica chegou à casa da paciente e ela não estava. Nesse dia, estava apenas Dona Maria explicando que sua sobrinha passaria alguns dias na casa do pai. A tia de Rebeca e a at tentavam entrar em contato por telefone com a mãe da criança e nesse ínterim, conversavam na cozinha. Passados alguns minutos a mãe retornou a ligação e explicou que havia esquecido de avisar a acompanhante terapêutica de que sua filha não estaria em casa para o atendimento daquele dia.

Durante a conversa na cozinha, Dona Maria dizia à acompanhante que estava terminando seus afazeres para ir a um evento que teria em seu condomínio. Era uma família que estava mudando de casa e colocou todos os objetos, mobílias, roupas, eletrodomésticos, entre outros pertences, à venda. O típico evento que acontece nos condomínios chamado "Vende Tudo". Ela dizia que vendiam coisas velhas, mas que eram coisas boas.

Como naquele dia não teria o atendimento, a acompanhante decidiu dedicar alguns minutinhos para estar com a tia da criança. Ao se despedir, Dona Maria já estava quase pronta, então a acompanhante ofereceu uma carona já que passaria na frente da casa "vende tudo" no caminho de volta.

Ao chegarem, Dona Maria insistiu que a acompanhante entrasse para ver como tinham coisas boas lá dentro. Ela aceitou o convite entendendo que talvez se tratasse de uma comunicação significativa por parte da tia, um momento especial. Ao adentrarem na casa, Dona Maria andava ao lado da at mostrando toda a beleza que se escondia ali naqueles objetos desgastados pelo tempo. Ao final, Dona Maria 
mostrou à acompanhante uma toalhinha de lavabo bordada. Havia nela manchas amareladas pelo tempo, explicou que tinha um procedimento que ao ser realizado deixaria o pano novinho e branquinho novamente. A acompanhante escutou como se fazia o procedimento e agradeceu pelo que havia aprendido ali. Dona Maria resolveu comprar alguns objetos, dentre eles a toalhinha de lavabo que estava manchada. As duas foram embora e a acompanhante aproveitou para deixar Dona Maria novamente em casa.

Durante as férias, a acompanhante precisou ir à casa da família para deixar um documento que a mãe de Rebeca havia pedido. Dona Maria a recepcionou com um presente, disse que havia lavado a toalhinha e realizado aquele procedimento que ensinou à acompanhante aquele dia. Mostrou como o pano havia ficado bonito novamente, além de todas as manchas que haviam saído. A toalhinha parecia nova e era vistosa. O bordado colorido aparecia ainda mais, era delicado. Estava dobrado, limpo e cheiroso. A acompanhante agradeceu o presente, elas se abraçaram.

\section{Parte II}

A primeira intervenção realizada pela acompanhante terapêutica objetivou abrir um espaço de escuta e visibilidade tanto para a dor da criança, como para a dor de Dona Maria, viabilizando que o encontro acontecesse através da intensificação do registro empático. A partir disso, pôde haver a abertura necessária para que a criança reconhecesse em sua dor também a dor da tia, e Dona Maria, por sua vez, reconhecesse em si a dor que também era de sua sobrinha. Com isso, ambas puderam perceber o desamparo vivido e ao reconhecerem-se através dessa dor ensaiar alguma aproximação entre elas.

A segunda intervenção buscou devolver a dignidade perdida pela tia naquele lar. Dona Maria estava sempre a serviço de todos, mas não era reconhecida em seus sentimentos, em sua dignidade. Quando mencionou que gostaria que a acompanhante entrasse para ver que existiam coisas boas "lá dentro", apesar de serem velhas, fazia um convite à at para que a mesma testemunhasse as coisas boas que carregava em si, daquilo que era velho, mas que guardava o seu valor. Ela dizia, na verdade, sobre si mesma e de como se sentia desvalorizada pelas pessoas a sua 
volta. Era como se ninguém percebesse a sua beleza e o que portava de bom dentro de si.

As duas intervenções descritas acima indicam possibilidades de aproximação tanto entre acompanhado e família, quanto família e acompanhante. Através do vínculo estabelecido com a acompanhante terapêutica houve a possibilidade de integrar aspectos antes soltos que circulavam na relação familiar e que não encontravam destino. Segundo Safra (2000), existe uma "demanda de modelos que auxiliem a fundamentação ética e teórica do acompanhamento terapêutico, para que possa ser uma prática realizada com rigor." Nesse sentido, e a partir do caso explicitado acima, podemos compreender que inicialmente uma ação destinada a alguém que se encontra devotado, é uma ação que se humaniza e acaba por se transformar em gesto (Safra, 2006).

Os trabalhos escritos no campo do Acompanhamento Terapêutico, em sua maioria, acabam se ocupando da relação entre acompanhante e paciente, deixando de considerar devidamente a importância do ambiente familiar na realização dessa clínica. Safra (2000), aponta que, em sua visão, "o acompanhante oferece fundamentalmente a seu paciente um lugar "(p.14). No caso apresentado acima, constatamos que a oferta de lugar também pode se dar na relação construída com a família do acompanhado, a depender de momentos oportunos, assim como da abertura e disponibilidade encontradas nela.

Destaca-se, a partir das intervenções apresentadas, o valor e a importância do gesto como instrumento a ser utilizado a favor do diálogo e do encontro com a família do acompanhado. A meu ver, o gesto carrega em si uma potência comunicacional diferenciada quando comparado à palavra. Safra (2000) em importante contribuição nos alerta de como:

É curioso que a psicanálise tenha se ocupado tão pouco da ação e do gesto do homem no mundo, quando é por meio dessas capacidades que o indivíduo cria o mundo e o transforma. O fundamento da criatividade humana se encontra na capacidade de agir.(p.97)

Segundo Safra (2006), "é fundamental compreender que há diversos tipos de ação e é importante dar o necessário lugar ao agir e ao gesto na constituição do ser humano." (p.97). No caso apresentado, podemos dizer que a ação da acompanhante destinada à tia da criança - começada pelo olhar que lhe acolhia a dor e seguida pela 
oportunidade de narrar sua história de vida à sobrinha -, somada ao lugar ofertado à comunicação que fizera de mostrar o que havia de bom dentro de si, transformou-se em gesto constitutivo dando lugar à materialidade poética (Safra, 2005) representada pelo pano bordado (beleza) e limpo (dignidade). Dona Maria retribuiu à ação da acompanhante encontrando lugar e transformando-se em gesto, o qual, por sua vez revelou "a pulsação do encontro humanizador" (Safra, 2006, p.99).

Além disso, e a partir do caso explicitado, penso que podemos refletir sobre como o velho e o pobre são vistos como descartáveis em nossa sociedade. A tia de Rebeca, que já era uma senhora, era a representação desses dois significados. A história de pobreza vivida pela família em tempos passados, muito provavelmente precedida por uma humilhação social (aspecto verificado no contato com Dona Maria, evidenciado pela sua comunicação corporal, pelas histórias contadas à acompanhante e pelo modo como a sobrinha a tratava, deflagravam essa questão), havia um desenraizamento que fazia com que a criança fosse arredia em relação à tia justamente para se ver livre desse sofrimento, dor sentida e passada de forma inconsciente e transgeracional.

Muito embora, nem sempre encontremos na família do acompanhado a possibilidade de abertura para que o encontro aconteça, é possível arriscarmos, sempre que possível, intervenções nesse sentido a fim de abrir caminhos para que a comunicação significativa aconteça. Algumas famílias apresentam grande sofrimento, e muitas delas grande cristalização em seu modo de ser, evitando que tudo isso seja acessado por alguém. Porém, quando aceder a essa dor torna-se possível, o encontro pode vir a se transformar na beleza de um delicado pano bordado. 


\subsection{Vampirismo Familiar: Introjeção Extrativa e Duplo Vínculo}

(...) é que eu sinto que aqui no meu prédio têm vampiros querendo sugar o meu sangue e os meus pensamentos.

A frase em epígrafe foi dita por uma paciente atendida em Acompanhamento Terapêutico. Seus atendimentos duraram em torno de cinco anos. Às vezes ela não tinha voz própria, não tinha pensamentos próprios, e se sangue representava a vida que pulsava e corria em suas veias, ela sentia constantemente o medo de ser roubada e sugada no que havia de mais vital em si...

Mariana era o tipo de pessoa desconfiada, sempre muito preocupada com a possibilidade de que seus vizinhos a escutassem, a enxergassem, a encontrassem. O seu medo? O de que alguém pudesse prejudicá-la. Em alguns momentos, o seu medo era da morte (compreendida como a morte psíquica). Vivia com a mãe e apenas com ela, pois o seu pai, apesar de morar na mesma casa, quase nunca aparecia. Por inúmeras vezes procurei conhecer e conversar com o seu pai, mas a sua mãe dizia que era impossível e que o marido não gostava de aparecer. Desde o primeiro encontro com Mariana era notável a sua desconfiança, e ao mesmo tempo o seu anseio em poder ser encontrada, escutada e vista por alguém, justamente o contrário daquilo que dizia querer...

A escolha da frase que inicia o capítulo refere-se a uma questão paradigmática encontrada em muitos casos de Acompanhamento Terapêutico. Em minha experiência clínica, pude observar que, pessoas gravemente adoecidas que necessitam da presença de um acompanhante terapêutico em suas vidas, costumeiramente são pessoas que carregam cicatrizes profundas na alma. Tornaramse desconfiadas, vendo no isolamento, por vezes, o seu único modo de existir no mundo (Tufolo, 2014). São pessoas que apesar de isolarem-se, anseiam pelo encontro com o outro, residindo nisso um paradoxo existencial (Safra, 2004; Winnicott, 1983). Podemos observar esse funcionamento em muitos casos nos quais os pacientes não têm quase nenhum (e por vezes nenhum) convívio social, revelando que além de serem pessoas que não puderam ser reconhecidas em sua singularidade pelo outro, sofreram histórias de abuso imposto por um terceiro (em alguns casos, abuso tanto físico, quanto psíquico); optaram, muitas vezes, pelo isolamento, já que o 
ambiente não se mostrou confiável desde o início de suas vidas (Winnicott,1983). Retomamos, nestes casos e a partir de Winnicott (1958) a questão do confiar, em que:

(...) a falha da adaptação suficientemente boa do ambiente, produz as distorções psicóticas do conjunto ambiente-indivíduo. Os relacionamentos provocam uma perda da sensação de ser, que vem a ser readquirida somente pelo retorno ao isolamento. O estar isolado, porém, torna-se cada vez menos puro à medida que a criança afasta-se do início, pois envolve cada vez mais uma organização defensiva para repudiar a intrusão ambiental. (p.310)

Winnicott (1990) apresenta a concepção de que no desenvolvimento emocional primitivo do bebê o cuidado físico é sentido como proteção, amor e cuidado pelo bebê, e que no caminhar dessa trajetória se os cuidados destinados à criança continuarem a atender às suas necessidades de forma satisfatória ela crescerá confiando no ambiente, tendo registros desse cuidado em seu íntimo. Por outro lado, se essas necessidades básicas não foram atendidas e sentidas pelo bebê como amor, mas sim como ameaça à sua existência, ele crescerá tendo restrições ao ambiente, sentindo em seu mais íntimo ser que as pessoas podem não ser confiáveis. A descrição desse processo é de fundamental importância na clínica do Acompanhamento Terapêutico, uma vez que as pessoas normalmente atendidas nessa modalidade clínica apresentam frequentemente o sintoma da desconfiança, gerando a famosa reclusão tão testemunhada por nós acompanhantes terapêuticos: a típica imagem das tartarugas que se escondem em seus "cascos protetores".

É importante estarmos atentos aos sintomas desses pacientes nessa clínica, pois tais aspectos, muito provavelmente, revelam sobre o ambiente ao qual estiveram ou estão inseridos. Bollas (1992), constrói reflexões acerca do que chamou de "introjeção extrativa", no qual uma pessoa rouba invariavelmente de outra aspectos elementares da vida psíquica para poder possuí-los e anestesiar a capacidade de self da "vítima", frisando que:

Quando uma pessoa invade o território psíquico de uma outra, não somente deposita uma parte indesejada de si próprio, como na identificação projetiva, mas, de alguma forma, também toma alguma coisa. No mínimo, rouba a paz de espírito do receptor. Essa é de fato uma das funções da identificação projetiva. Colocando partes indesejadas de si próprio em uma outra pessoa, o projetor usufrui de uma paz de espírito limitada, um estado psíquico extraído do receptor que é deixado em confusão. (Bollas, 1992, p. 206207) 
Se tivermos a clareza de que as experiências emocionais das pessoas estão também atreladas ao período inicial de suas vidas (Winnicott, 1983), constataremos que o modo de ser de determinada pessoa comunica o que ela viveu em sua trajetória, incluindo inclusive, tudo o que houve de traumático, como bem aponta Bollas (1992):

\begin{abstract}
Podemos observar como algumas crianças podem desenvolver padrões pertinentes de comportamento, se foram violadas por pais que roubaram partes importantes de suas vidas psíquicas. Um ladrão pode estar violando um lar para roubar os objetos pessoais de uma família, e nesse momento seu ato pode espelhar suas próprias experiências quando criança, revertendo compulsivamente seu padrão de vida através de uma compensação violenta. (Bollas, p. 1992, p. 206).
\end{abstract}

Percebemos, através da experiência, que os pacientes mais desconfiados e que apresentam como principal sintoma o medo das pessoas, revelam, via de regra, histórias precedidas de eventos negativos que envolvem especialmente o contato íntimo com seus cuidadores.

Em meu contato com algumas famílias durante os acompanhamentos, ficava evidente o quanto algumas delas eram bem opressoras. Isso transparecia nos pedidos que faziam e na forma como conduziam determinadas situações com os pacientes acompanhados, os quais foram revelando com o tempo suas histórias precedidas pelo que podemos chamar de uma "sugação emocional", ou como colocado por Bollas (1992), mecanismos de "Introjeção Extrativa". Baseada nessa constatação de alguns casos atendidos em Acompanhamento Terapêutico, decidi escrever esse capítulo e relatar o quanto algumas famílias pareciam sugar partes do self de alguns pacientes. Muito comum encontrarmos nesses modos de relação familiar a subjugação como modelo relacional. Ainda que o acordo se desse em nível tácito, as regras deveriam ser claramente seguidas pelos membros da família.

Certa vez, em um Acompanhamento Terapêutico que já acontecia há tempos, reparei que a paciente começou a ficar calada durante o atendimento e quando algo Ihe era perguntado respondia secamente, como se não quisesse revelar nada sobre si. Tudo aquilo parecia muito estranho, pois não era o padrão de relação que ela havia estabelecido até ali durante os atendimentos, a mudança se deu sem motivo aparente. Com o tempo a paciente foi dizendo que se contasse algo, a sua mãe poderia ficar brava, e que dizia o seguinte a ela: se ela (at) não conta coisas íntimas da vida dela para você, porque você tem que ficar contando as suas? " (sic). A mãe claramente a oprimia em relação ao que dizer nos atendimentos. Um dia, essa mesma paciente me 
contou um segredo e saiu do atendimento muito preocupada com o que a sua mãe poderia pensar sobre o fato dela ter me contado algo tão íntimo. A mãe depois de um tempo enviou-me uma carta justificando a fala do filha e dizendo que não havia problemas de que ela me contasse algo, apenas que a orientava a não contar para todo mundo (como se a acompanhante fosse todo mundo) e que a filha se confundia a todo instante com o que ela dizia...

No caso ilustrado, a mãe demonstrava de diversas maneiras (não só nessa passagem descrita acima, como em diversos outros momentos do processo), o quanto não the agradava o fato de sua filha confidenciar segredos à acompanhante terapêutica. Esse movimento era compreendido por nós como uma tentativa da mãe de impedir que uma relação de intimidade pudesse ser estabelecida entre a filha e uma terceira pessoa. O medo da mãe era bem evidente durante todo o processo, chegando a relatar numerosas vezes a sua preocupação quanto ao "apego" que sua filha desenvolvera pela acompanhante. A relação estabelecida entre a sua filha e a acompanhante terapêutica era vivida por ela como algo realmente ameaçador.

Já em relação à paciente, ela de alguma forma captava a insegurança sentida por sua mãe e o quanto não a agradava o fato de vê-la se aproximar da acompanhante (muito embora a mãe, verbalmente e conscientemente, dissesse o contrário disso). Essa era a mensagem ambígua gerada por essa mãe, pois sinalizava não querer que a filha contasse coisas de si à acompanhante, e logo em seguida negava qualquer tipo de incômodo com essa situação. No fundo, a mãe sugava partes de seu self por não permitir que a paciente viesse a se vincular a qualquer outra pessoa que não fosse ela mesma e, portanto, que pudesse se desenvolver.

O antropólogo George Bateson, membro da equipe interdisciplinar de Palos Alto (Califórnia), em sua experiência como pesquisador de processos comunicativos e também de atendimentos à pacientes com diagnóstico de Esquizofrenia observou um fenômeno muito interessante que denominou de "duplo vínculo", cuja organização familiar se estabelecia através de duplas mensagens acabando por confundir o seu receptor. Apesar de sua antropologia se diferenciar da de Bollas uma vez que estudou a interação entre pessoas pelo viés da comunicação e não tanto pela via da intersubjetividade considerando aspectos intrapsíquicos inconscientes, penso que este autor contribui significativamente com as suas descobertas para a compreensão 
de um modo bem peculiar de organização comunicacional familiar encontrado em muitos casos atendidos na clínica do Acompanhamento Terapêutico.

O fenômeno de "duplo vínculo" descrito por Bateson (1972) foi compreendido como um dos fatores que poderiam levar certos pacientes a desenvolverem uma falha na comunicação. Em sua trajetória como analista e a partir de tal experiência demonstrou certa inquietação na busca por compreender por que os pacientes com diagnóstico de Esquizofrenia apresentavam tanta dificuldade em compreender o que Ihes era comunicado. Uma frase que se propunha a passar mensagem " $x$ " era compreendida por esses pacientes como "y". Assim sendo, se debruçou na investigação e compreensão desse fenômeno concluindo que na história de vida de alguns desses pacientes havia algo de realmente muito ambíguo nas mensagens que Ihes eram direcionadas e justamente por isso é que eles acabavam desconfiando se o que Ihes era dito poderia ser isso ou aquilo outro.

Se dissermos a um paciente com Esquizofrenia (normalmente paranoíde) "nos vemos amanhã" ele poderá interpretar essa frase como: a) ela está dizendo que amanhã eu vou morrer; b) ela quer transar comigo; c) ela quer me ver amanhã porque provavelmente colocará veneno em meu refrigerante; d) isso é um teste; e) amanhã algo terrível vai acontecer e eu não vou "cair nessa", etc. Seríamos capazes de escrever aqui muitas e variadas interpretações feitas pelos pacientes em um contexto qualquer desses e a distorção que fazem, assim como na frase acima na qual o objetivo claro era apenas ratificar que no dia seguinte ocorreria um próximo atendimento. Ademais, esse funcionamento também pode ser compreendido como a incapacidade de indiscriminação eu/outro característica nos casos de psicose (Winnicott, 1958), no qual tudo o que se diz ao paciente é compreendido por este como algo pessoal e com viés fusional, já que a falha ambiental não propiciou variáveis suficientes para alcançar o processo de integração no qual a pessoa se sinta uma pessoa total se relacionando com outras pessoas totais (Winnicott, 1990). Ou seja, a frase acima não poderia referir a algo puramente externo, mas sim a algo que diz respeito à "nossa relação" (at-paciente), sendo, portanto, compreendida apenas subjetivamente, e não objetivamente.

Winnicott (1958) ao desenvolver a teoria da comunicação destaca que o indivíduo que é afetado por significativas falhas ambientais em um estágio muito precoce do desenvolvimento sente tal fenômeno como intrusão o que o leva a reagir 
prematuramente. Sendo assim, "a sensação de ser é perdida nessa situação, e pode ser readquirida somente por uma volta ao isolamento. "(p.310). Winnicott (1958) esclarece que:

\begin{abstract}
O amor da mãe e sua estreita identificação com o bebê fazem-na consciente da necessidade deste, o que a leva a providenciar alguma coisa mais ou menos no lugar certo e no momento certo. Essa situação, muitas vezes repetida, dá início à capacidade do bebê para usar a ilusão, sem a qual nenhum contato seria possível entre a psique e o ambiente. (p. 311)
\end{abstract}

Desse modo, Winnicott esclarece, a partir da teoria da comunicação, que o trabalho a ser desenvolvido com esse tipo de paciente deverá passar pela compreensão dos fenômenos da realidade subjetiva, e não objetiva. A falta de condições ambientais favoráveis não possibilitou ao bebê a integração de aspectos internos fazendo-o se sentir real, ele parou na realidade subjetiva e, portanto, percebe o mundo de maneira subjetiva. Segundo Winnicott (1958) há algo de traumático nisso, pois o mundo objetivo e real se colocou prematuramente a essa criança impedindo-a de se desenvolver a partir de um sentimento de segurança em relação ao ambiente. É nesse momento que:

Uma falha ambiental precisamente aqui faz o indivíduo começar com um potencial paranoide. (...) Como defesa contra as terríveis ansiedades do estado paranoide nos primeiros tempos de vida, não é raro surgir um estado organizado ao qual já foram dados diversos nomes (por exemplo, introversão defensiva patológica). $O$ bebê vive permanentemente em seu próprio mundo interno, o qual, porém, ainda não está solidamente organizado. 0 complicador da perseguição externa é mantido a distância através de uma fuga à integração, evitando o estado de unidade. (p. 314)

Retornando à concepção de "duplo vínculo" de Bateson (1972) também encontramos indícios, na análise feita por ele em relação aos pacientes atendidos com diagnóstico de Esquizofrenia, da existência de uma experiência traumática revelada através do discurso aparentemente ininteligível:

De que maneira um indivíduo humano adquire uma capacidade imperfeita para discriminar entre esses sinais específicos? E quando examinamos os seus discursos, encontramos que, nessa linguagem peculiar que é a salada de palavras do esquizofrênico, ele está descrevendo uma situação traumática, que tem em si um embrolho metacognitivo. (tradução nossa, 1972, p.8) 
O autor ressalta a presença de uma problemática de ordem comunicacional vivenciada por esses pacientes. É recorrente, em muitos casos de Acompanhamento Terapêutico, encontrarmos a presença de mensagens duplas por parte dos familiares, o que possivelmente, segundo este teórico, influenciaria no processo de confusão desses pacientes ao compreenderem o sentido do que Ihes é dito. Esse processo é descrito por Bateson (1972) não como uma única experiência traumática na vida do paciente, mas como uma experiência tão reiterada que acaba por transformar-se em expectativa. Esse fenômeno, estaria relacionado ao fato de os pacientes sentirem-se sempre tão inseguros e confusos em relação ao que percebem, uma vez que suas percepções foram reiteradas vezes negadas por um outro, mesmo quando fidedignas.

No caso apresentado anteriormente, apesar de a paciente não ter a consciência do quanto era oprimida por sua mãe, comunicava através de sua preocupação e delírio (vampiros em seu prédio) o temor e o incômodo de ser sugada. Ela dizia que a única pessoa em quem poderia confiar era a própria mãe, a mesma que a afastava de toda e qualquer pessoa, fenômeno que era compreendido por ela como proteção materna exercida em relação a todo o "MAL" que havia no mundo. Sua mãe a controlava, inclusive, em relação ao que dizer às pessoas, alegando que nem todos eram de "confiança" e assim plantando e alimentando cada vez mais desconfiança e medo em sua filha, para logo em seguida dizer que não sabia o porquê de tanta desconfiança. A ambiguidade era frequente.

É comum que esses pacientes não percebam claramente o abuso emocional vivido em seus lares, acabando por se apegar à figura opressora de forma a sentiremse protegidos por ela. Essa paciente comunicava em seus delírios a "sugação" vivenciada de aspectos do self e o seu medo de perder aspectos pensantes e vitais de seu ser. Bollas (1992), comenta sobre a falta de capacidade da vítima em processar a introjeção extrativa:

Com a sua mente extraída pelo outro, a criança terá pouca capacidade para processar a experiência de ser vítima da introjeção extrativa e, portanto, irá saber de alguma forma elementar, muito pouco do que the aconteceu. Saber no sentido de ser capaz de representar mentalmente a natureza do fenômeno intersubjetivo que experienciou. (...) a perda da mente pode ser armazenada na memória do indivíduo somente como um acontecimento definidor da vida que está além da compreensão. (Bollas, p.207) 
Como apontado anteriormente, o fenômeno da paranoia/persecutoriedade é um elemento a ser altamente considerado na clínica do Acompanhamento Terapêutico. Bollas (1992) diferencia a paranoia oriunda de sentimentos hostis e que entra em curso através de uma dinâmica projetiva, daquela que é resultado de constantes extrações parentais. Parece-me importante ressaltar essa diferenciação, uma vez que na clínica psicanalítica tradicional a paranoia se tornou predominantemente compreendida enquanto projeção, ao invés de ser considerada, em alguns casos, e especialmente nos de psicose, como a revelação de um ambiente não confiável no transcurso de vida do paciente (Winnicott, 1983).

No caso apresentado neste capítulo, torna-se fundamental, a meu ver, ter a clareza de que a comunicação da paciente sobre os vampiros do mundo externo dizia muito mais sobre a comunicação em relação a toda violência sob a qual estava submetida do que a algo puramente projetivo, somente. Ela comunicava, sobretudo, sua trajetória oriunda de constantes extrações parentais.

Outro fenômeno presente e relacionado ao que foi abordado até aqui é o incômodo de alguns familiares quando estes percebem que o paciente tem encontrado fora do lar uma outra espécie de relação. Uma vez que o acompanhante terapêutico possibilita a oferta de lugar (Safra, 2006), possibilita concomitantemente ao paciente a construção e/ou recuperação daquilo que foi sentido como roubado, extraído e/ou sugado em relações anteriores:

O paciente procura recuperar a sua mente e, enquanto o analista o ajuda a
pensar e a se reapoderar dos afetos, dos processos mentais e basicamente
da estrutura psíquica, o analisando reage à função transformacional do
psicanalista com alguma coisa parecida com uma ânsia de objeto e,
eventualmente, amor. (Bollas, p. 208)

Esse fenômeno acima explicitado por Bollas e encontrado em muitos casos de Acompanhamento Terapêutico é observado especialmente quando, em determinado momento do processo, os pacientes começam a pedir mais horas e às vezes até mesmo, mais dias de atendimento a depender da necessidade e lou possibilidade financeira. Percebemos com isso, que há uma etapa inicial do período de vinculação na qual o paciente anseia pelo descobrimento e/ou redescobrimento da vida ao lado do acompanhante. É como se por um determinado tempo a figura do acompanhante terapêutico fosse mesmo central na vida do paciente; com o tempo isso passa a se estender aos demais, rumo ao que se busca realmente com o início do 
Acompanhamento Terapêutico: a reinserção social para além dos muros institucionais, a incluir a instituição familiar. É então que o desafio se inicia na relação com os familiares do acompanhado, assunto que será abordado no subcapítulo 4.6 (Não vá tão longe: a metáfora do combustível). 


\subsection{A Família no setting do Acompanhamento Terapêutico}

A família ocupa um lugar primordial nesse emaranhado complexo e por isso não podemos the dar as costas. (Frank, 2013, p. 2 - tradução nossa)

É interessante pensarmos sobre a família no setting dos acompanhamentos, pois não é ela que o adentra, e sim nós acompanhantes terapêuticos que adentramos os lares e passamos a participar do cotidiano dessas pessoas. Convém lembrar que, a presença do acompanhante é intrusiva por natureza, ainda que façamos um grande esforço para não "atrapalhar" produzimos olhares e movimentos. A simples presença, ainda que nada seja dito, já é capaz de alterar naquele curto espaço de tempo a dinâmica de funcionamento da família. Como bem aponta Frank (2017) a presença do acompanhante terapêutico no mundo familiar, tanto quanto na instituição, se caracteriza por si só como uma intervenção. Não são somente os pacientes que aguardam a nossa chegada, as famílias muitas vezes preparam-se também para nos receber, e nesse contexto muitas variações podem ser observadas, desde a arrumação da casa até o adiamento de atividades tendo em vista a nossa chegada.

O modo como somos recepcionados tanto pela família como pelo acompanhado revela, via de regra, a forma como se organizam internamente. Há uma perspectiva importante na clínica que compreende o paciente não somente em relação ao conteúdo que nos traz em sessão, mas sim e principalmente, em relação à forma como o faz durante a sessão (Safra, 2004). Essa compreensão também nos auxilia a pensar a clínica do Acompanhamento Terapêutico. Uma moça simpatizante da doutrina oriental com pressupostos zen-budistas se utilizava desse discurso para dizer o quanto estava no caminho da "paz interior", muito embora esse fosse o seu discurso, o que se observava era o contrário disso. A forma com a qual se relacionava com o outro dizia muito mais sobre uma forma autoritária do que pacífica em suas relações.

Havia uma incongruência entre o seu discurso e modo pelo qual se relacionava, a saber, o de fazer com que o outro lhe servisse sempre. Penso ser importante essa perspectiva, pois apresenta material clínico indispensável à compreensão dos conflitos vivenciados pela pessoa acompanhada. Da mesma forma, observamos funcionamento semelhante no contato com as famílias, aquilo que nos dizem, mas que é incompatível com o sentimento contratransferencial que temos em sua 
presença. Muitas vezes a família nos trata com doçura aparente, por exemplo, mas na forma de olhar e de interagir a hostilidade escapa e é sentida por nós. Safra (2006) nos esclarece sobre a importância do corpo sensível do clínico:

\begin{abstract}
É importante perceber que, por termos um corpo vivo, quando estamos frente a alguém, nós não só o escutamos, mas também o sentimos. Somos afetados em nossa sensibilidade, em nossa corporeidade por aquilo que ele diz ou faz. Só na medida em que possamos transitar pelas diversas imagens corporais que emergem a partir de nosso corpo, poderemos apreender as experiências do Outro. Daí a questão importante da presença psicossomática do analista. $O$ analista, nesse vértice, não só escuta, mas sente. A corporeidade do analista revela a verdade do Outro. É por essa razão que se torna importante poder compreender profundamente a questão da sensibilidade do corpo. (p.43)
\end{abstract}

Às vezes a sensação oriunda da interação entre paciente-acompanhado e acompanhado-família é tão forte que acaba por afetar o corpo de todos os envolvidos, sinalizando o que de mais verdadeiro ocorre ali. Em importante contribuição, Possani (2010) trata sobre o fenômeno do sentir com abordando-o a partir da perspectiva ética apresentada por Safra (2004), a qual compreende a corporeidade do acompanhante terapêutico enquanto fenômeno que acontece e "que se põe em movimento e em contato anteriormente à capacidade representativa" (p. 22).

Outra situação recorrente, pelo menos em minha experiência, é a de alguns familiares que demandam uma atenção antes mesmo que possamos chegar até o paciente. Em um dos casos atendidos, a mãe de uma moça me encontrava no corredor de sua casa antes mesmo que eu pudesse chegar até o dormitório que a paciente se encontrava. Quando a cumprimentava, dizia-me como estava e emendava um assunto ao outro. Mendonça (2017), nos alerta sobre a importância de compreendermos o Acompanhamento Terapêutico enquanto enquadre aberto, mas também sobre a necessidade de dentro dessa configuração realizarmos pequenos fechamentos de enquadre.

Graciela Bustos (Frank, L. M et al., 2016) em seu trabalho como chefe do Programa de Saúde Mental do hospital de San Luís, Argentina, desenvolveu um importante dispositivo de atendimento denominado Acompanhamento Terapêutico Dual, no qual são destinados, conforme a complexidade de cada caso, dois acompanhantes terapêuticos à residência do paciente. Esse modo de trabalho foi pensado a partir das vicissitudes encontradas nos casos em que tanto o paciente quanto a família necessitavam de atendimento. $O$ grande desafio era o de oferecer 
um cuidado às famílias que se negavam a procurar atendimento, sustentando e defendendo a ideia de que apenas o paciente precisaria de ajuda.

\begin{abstract}
O acompanhamento dual implica trabalhar com dois acompanhantes ao mesmo tempo e na mesma cena. Ambos sustentam o mesmo enquadre temporal e espacial, chegam juntos e vão embora juntos; devem ser muito flexíveis e tolerantes, esperar que a família faça os primeiros movimentos, devem se manter na expectativa, dispostos à escuta e evitar qualquer tipo de intervenção diretiva. (Frank, L.M et al., 2016, p.187)
\end{abstract}

Bustos (2016) explica que os pacientes atendidos pelo serviço do hospital vinham de contextos familiares com problemáticas muito complexas, eram famílias altamente conflitivas e que não conseguiam conter os seus membros, além do mais, observava-se que as famílias, assim como os pacientes atendidos, também apresentavam dificuldades de socialização. A partir disso, frisa que "é necessária uma grande flexibilidade no trabalho com essas famílias, enquadres menos estruturados para encontrar formas de aproximação à dinâmica familiar e estabilizar um tratamento possível. “(Bustos, 2016, p.185-186). Segundo a autora:

A experiência mostrava que quando se tentava trabalhar em domicílio, a família invadia o cenário permanentemente, dando indicações ou manifestando descontentamento e desqualificação do acompanhamento. Isso evidenciava relações vinculares muito complexas e altamente patológicas. (p.187)

O dispositivo de Acompanhamento Terapêutico Dual é indicado nos casos em que há a necessidade de diminuir as ansiedades familiares, permitindo que todos os integrantes sejam escutados (Bustos, 2016), viabilizando "alternativas de cuidado menos custosas para todo o grupo familiar e também para a equipe tratante, a qual às vezes se sentia diante de uma barreira, no momento em que percebia a família, muitas vezes, como obstáculo intransponível" (tradução nossa, Bustos, 2016, p.192)

Nessa abordagem, é oferecida à família a possibilidade de estabelecer vínculo com o acompanhante terapêutico que mais se identificar, ficando este a cargo de acompanhar a família de maneira sutil, sem que esta se perceba sendo efetivamente acompanhada, pois um dos desafios com essas famílias é justamente o fato de elas dizerem que não precisam de acompanhamento ou se negarem a isso. A mãe, por exemplo, que se aproxima de determinado acompanhante e não de outro, sentindose mais à vontade na presença daquele, tem a liberdade de eleger, digamos assim, o seu "objeto transferencial", enquanto que o outro acompanhante terapêutico realiza o 
trabalho proposto com o paciente. É interessante pensarmos que nesse modelo a família é altamente considerada. Bustos (2016) assinala que:

(...) as famílias vão se afastando de seus espaços sociais, se isolam criando
normas próprias, as quais as afastam das convenções habituais. Os at's
estão incluídos nesse contexto como portadores das normas sociais, e -
como ponte com o exterior - ajudam a retomar o contato perdido,
restabelecendo vínculos. (p.189)

A experiência mostra-nos que familiares de pacientes encaminhados para Acompanhamento Terapêutico também encontram dificuldades de socialização, vão isolando-se cada vez mais, deixando de lado os seus sonhos, a sua vitalidade, vivendo em função do adoecimento familiar e revelando nisso o seu próprio adoecimento, caracterizado por uma espécie de "dependência da dependência do outro". 0 Acompanhamento Terapêutico Dual teve como origem o marco das intervenções múltiplas familiares, as quais nasceram da experiência de trabalho em situações com "famílias muito demandantes, com problemas internos de longa data". (Bustos, 2016, p.186). Ao que tudo indica, esse modelo tem funcionado de forma eficaz em contextos institucionais, fazendo-nos refletir sobre outras possíveis entradas e indicações em Acompanhamento Terapêutico que envolvam famílias demandantes.

A seguir e como exemplificação, serão ilustradas pequenas vinhetas clínicas nas quais a presença da família durante os atendimentos transformou o encontro possibilitando novos rumos.

\subsubsection{Um banho divertido}

Os atendimentos ocorriam no apartamento da família e normalmente estavam presentes Maria (08 anos), sua irmã mais nova (4 anos) além da funcionária da casa. Nos dias de atendimento Maria relutava em tomar banho antes de ir à escola, gostava de ficar brincando tanto quanto pudesse e ao final do encontro almoçava rapidamente enquanto assistia televisão. Nesse dia, antes de ir à escola Maria foi ao banheiro pois estava com dor de barriga. Quando saiu a acompanhante terapêutica sentiu um forte cheiro que não sabia ao certo de onde vinha. Quanto mais Maria se aproximava, mais forte o cheiro ficava. Foi então que a acompanhante se deu conta de que muito provavelmente Maria não havia se limpado direito. Na tentativa de evitar maiores constrangimentos à criança, sugeriu que naquele dia ocorresse o tão famigerado 
banho dos encontros. Maria, como sempre, estava resistente. Foi então que acompanhante sugeriu "um banho divertido". Apesar de hesitante no começo, assim que os brinquedos foram levados ao banheiro, Maria aceitou prontamente a brincadeira. Enquanto tomava banho, a acompanhante acompanhava do lado de fora do box participando da brincadeira com os brinquedos em mãos. Antes mesmo que a acompanhante pudesse entender de onde vinha um barulho de criança gritando, foi surpreendida pela irmã mais nova de Maria que veio do corredor da casa contíguo ao banheiro correndo e tirando toda a sua roupa para pular no box e brincar no banho com a irmã. Era água que espirrava de um lado, eram pulos e risadas do outro. A acompanhante inicialmente ficou assustada com tamanha intimidade e preocupada com a repercussão desse evento, já que a sua preocupação inicial era somente a de zelar pela higiene de Maria. O que antes era um simples banho, acabou virando um momento divertido, e mais, com a participação de outros integrantes da família. Como de costume, Maria pediu à acompanhante que a ajudasse a se trocar, e esta assim o fez. Naquele dia, foi à escola cheirosa e feliz.

\section{4. 2 Enquanto eu estudo, você zela por mim}

Os atendimentos quase sempre aconteciam no quarto de Rafael, um adolescente tímido que não conseguia sair de casa. No início dos atendimentos Rafael dizia sentir medo ao andar na rua, relatava que nessas situações tremia e até mesmo chorava. A nossa tentativa foi a de sair aos poucos, primeiro alguns metros de sua casa, depois alguns quarteirões e assim sucessivamente, sempre procurando estabelecer uma presença sensível às suas necessidades e limites. Com o tempo o medo era cada vez menor, até o dia em que Rafael passou a tratar tais momentos com naturalidade. A partir disso, começamos a programar saídas de seu interesse. Um dia, comentou sobre o modo como a sua mãe interrompia os atendimentos com os profissionais que Ihe atendiam. Dizia que por um período a mãe sustentava a situação, mas que depois de um tempo começava a implicar com os profissionais. Ali Rafael já me alertava sobre o que estaria por vir.

Um dos sonhos de Rafael era cursar física na USP, tinha uma inteligência acima da média, entretanto, as relações interpessoais ainda o aterrorizavam, não conseguia se relacionar com as pessoas do cursinho e por esse motivo mais faltava 
do que comparecia. Foi então que começamos a fazer cronogramas de estudo, separando por dias as disciplinas que deveria estudar já que apresentava facilidade para estudar sozinho. Por um tempo ele conseguiu se organizar assim, mas depois de algumas semanas, não mais. Um dia, sugeri que tentasse estudar enquanto eu estivesse por lá para sentirmos como seria. Surpreendentemente, disse que ao meu lado conseguia se concentrar nos estudos. Sendo assim, combinamos que eu chegaria e em silêncio ao lado dele ficaria. Assim o fizemos durante alguns encontros para que ele conseguisse estudar conteúdos importantes de cada matéria. Porém, certo dia sua mãe entrou no quarto e me viu sentada na cama enquanto ele estudava. Em nosso último encontro Rafael disse que a mãe cancelaria os atendimentos e que achou um absurdo eu estar ao lado dele sem "fazer nada" e ainda por cima ser paga para isso. Rafael disse discordar da mãe e apesar de explicar a ela que se tratava de um pedido dele para mim, a mesma encontrava-se irredutível. Tentei conversar com a mãe sobre a importância de minha presença sensível e silenciosa nos momentos de estudo de seu filho, mas foi em vão, ela nem sequer quis marcar o atendimento em consultório. A ideia era a de explicar o sentido desta intervenção e esclarecer que ela se daria apenas nas semanas antecedentes aos testes. Paralelamente a este evento, um dos membros da família havia marcado cirurgia na coluna, foi então que a mãe alegou precisar interromper os atendimentos, pois teriam que arcar com os custos desse outro serviço.

\subsubsection{Nessa festa, intrusos não entram!}

Era como um hábito, todas as vezes que o irmão mais novo (02 anos) de Richard (07 anos) acordava ia até o quarto e perguntava ao irmão mais velho se poderia participar conosco das brincadeiras. Sempre muito ciumento, todas as vezes Richard negava o pedido do irmão mais novo. Certo dia, Richard sugeriu que organizássemos uma festa em seu quarto, e assim o fizemos. Colocamos a música e começamos a dançar. Em dado momento Richard parou e disse: "vou fazer uma armadilha!" (sic). Amarrou barbante de um extremo ao outro da porta do lado de dentro do quarto, e sussurrou: "assim se meu irmão entrar ele vai cair. Nessa festa, intrusos não entram!" (sic). E continuamos a dançar em nossa "festa" particular. Por sorte, naquele dia o irmãozinho mais novo não tentou entrar no quarto. Ufa! 
Richard era bem apegado à mãe e havia toda uma questão em torno da "chegada" desse irmãozinho mais novo - intruso - em sua vida. Antes desse irmão, Richard vivia uma "festa" particular com a sua mamãe!!

\subsubsection{Goste de minha acompanhante, mas nem tanto!}

Em certa ocasião, fui contratada para acompanhar uma senhora que quase já não saía de casa porque encontrava-se em um estado depressivo. Quem me procurou foi o seu sobrinho. Essa senhora, a qual chamarei de Margarida, não havia constituído uma família e por isso continuava a morar com a mãe. Logo no início do tratamento o sobrinho havia me alertado sobre algo importante, que sua tia e avó formavam uma relação simbiótica e que, portanto, se a mãe de Margarida não gostasse de mim, não haveria atendimento. Eu ainda recém-formada e ingênua, caí na armadilha. Fui buscando me aproximar tanto da paciente, quanto da mãe. Acontece que a mãe da paciente realmente gostou muito de mim e em dado momento começou a fazer comparações da vitalidade que eu apresentava em relação ao estado depressivo da filha. Grande cilada! O que era para ser algo integrador se tornou um dos motivos pelos quais o atendimento foi cancelado, a paciente passou a ficar enciumada e o AT foi interrompido.

\subsubsection{Cuida de mim?}

Os acompanhamentos aconteciam na casa de Priscila. Ela encontrava-se em um estado depressivo significativo. Certa vez, fez-me um pedido inusitado, o de que eu fosse atendê-la algumas vezes no período da noite para que eu pudesse testemunhar a relação dela com a filha pequena (Rafaela). Dizia não conseguir atender às solicitações de Rafaela, sentia e sabia o quanto estava adoecida naquele momento. Essa foi uma situação embaraçosa para mim, pois como irritava-se com qualquer pedido que a filha fazia (desde ajudá-la a colocar as meias até a escovar os dentes), a pequena criança começou a fazer tais pedidos a mim. Sua filha tinha por volta de dois anos e meios de idade e ainda precisava de muitos cuidados. Quando sua mãe negava os seus pedidos ou se irritava, Rafaela olhava para mim com os olhos marejados de lágrimas e repetia o pedido que fizera há pouco à mãe. Em alguns 
momentos, Priscila pedia que eu a ajudasse com a filha, em outros, quando eu a ajudava, sentia-se incomodada. Às vezes, dizia que a filha precisava "se virar sozinha”, eu ficava sensibilizada porque ela ainda era muito pequena e realmente necessitava de ajuda para realizar algumas atividades. Um dia, Priscila pediu que eu levasse a filha até o banheiro para que escovasse os dentes, mas advertiu que não queria que eu a ajudasse, pois ela deveria fazer tudo sozinha. Fomos juntas ao banheiro e chegando lá Rafaela começou a me olhar com cara de choro e logo em seguida estendeu os seus pequenos bracinhos pedindo que eu a ajudasse a colocar o creme dental em sua pequena escova, ao fundo sua mãe gritava: não ajuda ela, tem que aprender a fazer sozinha! (sic). A criança olhava-me assustada...

\subsubsection{Na cozinha cabem quantos?}

Paulo havia cursado faculdade de gastronomia. Era na cozinha que se sentia realizado. Durante os atendimentos gostava de preparar doces para ao final comermos com café. Sempre preocupado em utilizar os melhores ingredientes e ansioso para saber se eu havia gostado de suas combinações gastronômicas, quando cozinhava sentia-se feliz. Os acompanhamentos também aconteciam fora de sua casa e normalmente ocorriam em alguma padaria, café ou confeitaria. O seu pai já estava aposentado e gostava de ficar em casa para ajudá-lo a cozinhar. O problema estava nas ocasiões em que recebia era quando recebia alguma encomenda, pois seu pai sempre "palpitava", e por vezes desvalidava a sua forma de fazer. Naquelas ocasiões, Paulo já não conseguia mais se aventurar a ser ele mesmo. Em dado momento, foi sugerido pela equipe de acompanhantes que esse talvez pudesse ser o projeto terapêutico singular de Paulo, ou seja, ser auxiliado nesse processo de autonomia, para que se sentisse mais seguro e confiante no preparo de suas receitas e encomendas. Isto acabou não sendo permitido pelo pai de Paulo, os acompanhantes se viram impossibilitados de realizarem qualquer tipo de trabalho nessa perspectiva, quando o pai estava por perto na cozinha sufocava não somente o filho, como também

os acompanhantes. É, parece que a cozinha no Acompanhamento Terapêutico é coisa séria... 


\subsubsection{Ajude-me a caminhar...}

Marta era uma médica ainda cheia de projetos e sonhos quando foi acometida pela Esclerose Múltipla. Estava em terapia e sua psicóloga a encaminhou para Acompanhamento Terapêutico. A psicóloga havia informado que apesar de Marta já ter 45 anos seu pai ainda queria entrar com ela nas sessões de psicoterapia. Nos primeiros encontros, Marta me apresentou o seu quarto e o que ali gostava de fazer. Um dos pedidos era o de voltar a caminhar sozinha e com mais segurança. Após os atendimentos iniciais em seu quarto, nos quais me contava sobre todos os sonhos que havia abandonado depois da doença, pediu que eu a auxiliasse a caminhar novamente. Os atendimentos então, passaram a ocorrer na rua em frente à sua casa e a cada dia arriscávamos novos passos. Após certo tempo, sentindo-se mais segura conseguiu dobrar a esquina, comemoramos! A sua vontade de ir mais além era evidente e foi justamente naquele momento que o pai de Marta começou a ficar incomodado. Em determinado momento de seu processo e tendo em vista tal avanço, Marta começou a pedir para irmos caminhando até a padaria próxima de sua casa, ali pedia um docinho e um café para acompanhar. Certo dia, Marta disse que seria melhor pararmos de ir à padaria, pois estava comendo doces toda a semana e que isso a estava fazendo engordar. Em nosso penúltimo encontro seu pai entrou no quarto sem pedir licença e começou a ofende-la dizendo que: "com essa história de ficar comendo doces você está ficando cada vez mais gorda" (sic). Marta pela primeira vez se defendeu e quando disse como se sentia ao pai, o mesmo saiu do quarto. No último atendimento seu pai comunicou que não teria mais condições financeiras para continuar a pagar a acompanhante terapêutica, além disso frisou que antes desse trabalho de Acompanhamento Terapêutico, ele e a filha se davam muito bem. Marta abaixou a cabeça e ficou em silêncio. A despedida foi na praça e ali pudemos conversar sobre o real sentido de seu pedido inicial quando nos conhecemos (voltar a "caminhar"), tanto quanto do motivo pelo qual o seu pai havia interrompido os atendimentos; Marta disse sentir muito pela interrupção dos atendimentos, mas que naquele momento ainda não tinha forças para fazer do seu modo, nem ao mesmo conseguia caminhar sozinha e que infelizmente ainda dependia muito de seu pai... 


\subsubsection{A vida através da janela}

Em conversa na sala, Sofia, mãe de Isabela, queixava-se do processo de AT que já não estava mais "ajudando a filha" a progredir. Reclamava de que Isabela já não queria mais sair de casa com ela, apenas com a acompanhante terapêutica. Enquanto a escutava percebi que, em um dado momento, o sofrimento em relação a toda a solidão que vivia aparecia. Disse-me: "quando eu era pequena, os meus pais não me deixavam sair de casa, eu ficava olhando através da janelinha da porta as pessoas lá fora" (sic). Eu disse: "é Dona Sofia, às vezes eu tenho a impressão de que a senhora ainda se sente assim, olhando o mundo pela janelinha de dentro, sem poder sair, olhando as pessoas lá fora". Dona Sofia começou a chorar copiosamente. Demorou até que pudesse se recompor. Depois disso, disse que gostaria de me mostrar algumas coisas que fazia, entrou no quarto e depois de alguns minutos voltou mostrando os seus bordados, quadros e artesanatos que estavam guardados e que, segundo ela, quase nunca mostrava a ninguém.

A perspectiva apresentada no presente capítulo teve como objetivo demonstrar e considerar, através de narrativas literárias sintéticas de casos clínicos, os familiares enquanto parte integrante do processo terapêutico e não alienados a ele. Compartilho do pensamento clínico de Mendonça (2017) quando diz que por vezes quem está a interromper algo não é a família, mas sim, o próprio acompanhante terapêutico que adentra o espaço familiar. Considero importante problematizar essa questão, pois em momentos pontuais, em minha experiência clínica, senti contratransferencialmente um certo incômodo com alguns familiares que apresentavam uma atitude intrusiva durante os encontros de Acompanhamento Terapêutico. Mendonça (2017) nos auxilia a pensar essa questão pois diferencia a presença familiar inerente ao próprio enquadre aberto do Acompanhamento Terapêutico, da presença familiar intrusiva que ocorre pela maneira de aproximação invasiva de algum familiar:

Há casos de familiares que costumam estar presentes ou apresentar-se com frequência durante os encontros. (...) não convém querer sustentar uma relação dual e ocupar profissionalmente o lar familiar como se fosse o nosso consultório ou um centro de reabilitação. Pois bem, outra coisa muito diferente é que a atitude de determinado familiar (ou garçom, etc.) seja intrusiva ou alienante em relação ao paciente, por exemplo, que entre no 
quarto sem avisar, etc.; mas essa intrusão não está marcada pelo enquadre em si, mas sim pelo fato de que há uma atitude intrusiva. (p.112)

Parece-me importante considerar a diferença entre 0 sentimento contratransferencial do acompanhante terapêutico no momento em que este sente-se invadido no contato com a família, do sentimento em relação ao trânsito habitual das pessoas que circulam na casa do paciente e que faz parte de algo inerente ao setting do Acompanhamento Terapêutico, uma vez que essa modalidade clínica pressupõe, fundamentalmente, a circulação de pessoas em torno do acompanhante/acompanhado, e principalmente, a interação com eles, seja direta ou indiretamente. Em minha experiência clínica, percebi que às vezes a conversa em torno da mesa, na sala de estar, cozinha, ou onde quer que seja, com a família reunida, reflete ganhos terapêuticos pois ela enquanto parte integrante do processo sente-se considerada e não excluída.

Ainda sobre a presença familiar no Acompanhamento Terapêutico, outra possibilidade que pode ser vislumbrada nesse mesmo viés da inclusão, seria a perspectiva dos familiares que também participam dos passeios com o acompanhante terapêutico e acompanhado, dependendo sempre, a meu ver, da pertinência de cada caso. Há notícias desse modelo de atendimento no programa de estágio em Acompanhamento Terapêutico da Universidade Paulista sob supervisão do Professor Dr. Kleber Barretto. O grupo de estagiários experenciou esse modelo de atendimento oferecendo a uma família que vivia situação de privação cultural a possibilidade de também desfrutar dos passeios durante o Acompanhamento Terapêutico.

Após tomar conhecimento desta experiência, comecei a refletir sobre a privação que muitas famílias vivem, especialmente no campo da saúde mental, e que podem ser localizadas não somente na escassez de vida cultural, como também, e principalmente, em termos de convívio social e lazer. Pensando nessa proposta, certa vez sugeri a um dos pacientes atendidos que a mãe dele também participasse de um passeio ao qual ela já havia, anteriormente, demonstrado interesse. O paciente ficou surpreso, mostrou ter gostado da ideia, muito embora dissesse que sua mãe talvez não aceitasse o convite. Conversamos sobre como a sua mãe, muito provavelmente, também sentia falta desses momentos de lazer e que vez ou outra poderíamos programar passeios com ela. No atendimento seguinte, o paciente contou que sua mãe não tinha aceitado o convite, por preferir passeios "em família". No caso 
específico desse caso, essa era uma queixa recorrente da mãe, pois a família sempre programava passeios, mas quase nunca isso se concretizava, uma vez que o marido passava a maior parte do tempo trabalhando.

No próximo capítulo, abordaremos uma outra forma de presença familiar durante os atendimentos, as quais marcam o discurso de alguns pais como orientação aos filhos antes dos encontros em Acompanhamento Terapêutico. 


\title{
4.5 Não vá tão longe: a metáfora do combustível
}

\begin{abstract}
Um exemplo particularmente instrutivo é o de uma espécie de peixes da família cichlidae (...) se há uma ameaça de perigo ou se a noite se aproxima, a mãe logo abre a boca e então todo o jovem cardume entra ali, onde permanece até que o perigo se dissipe ou que o dia amanheça. (Otto Rank, 1924, p.45)
\end{abstract}

Em minha experiência clínica observei muitas vezes a figura do acompanhante terapêutico sendo colocada justamente no lugar de sustentação do sintoma do paciente acompanhado e de sua família. Muitas famílias buscam o Acompanhamento Terapêutico para auxiliá-las em momentos de crise do paciente, na retomada de alguma atividade por parte deste ou até mesmo na busca por novas possibilidades de inserção na sociedade. Muito embora esse seja o pedido inicial por parte da família, o que observamos no decorrer do processo, salvo raras exceções, é justamente uma preocupação contrária quando por fim o paciente encontra alguma atividade carregada de sentido para si. A partir desse momento, críticas costumam ser levantadas e todo o cenário construído em meses de trabalho é desconsiderado para logo em seguida a família afirmar que o paciente "não dará conta" de iniciar tal atividade.

Algo comum se apresentou em diversos casos e demonstrou que a entrada do acompanhante terapêutico, para algumas famílias, se desdobrava não tanto no sentido de acompanhar o paciente em novos desafios, mas sim e sobretudo, no de sustentar a sua permanência de forma menos disruptiva em atividades rotineiras dentro da própria casa. É importante nos atentarmos ao fato de que em alguns casos o adoecimento se revela como única tentativa de ruptura com o meio. Isso se configura como um paradoxo, uma vez que o paciente adoece muitas vezes por não ter tido condições ambientais favoráveis para realizar o seu processo de desenvolvimento de maneira integrada, ao mesmo tempo em que, encontra no adoecimento uma possibilidade de se diferenciar do ambiente no qual está inserido. Nesta perspectiva, parece-me importante questionar de que forma poderíamos manejar a condução de um projeto terapêutico singular, já que a modalidade do Acompanhamento Terapêutico carrega em seu bojo o "facilitar" da ação de sair do paciente, algo que poderíamos entender como "tomar um fôlego" por parte do paciente, algo que o retira 
de todo o embrolho familiar adoecido. Porém, se esse movimento é percebido pela família, rapidamente um de seus membros convoca novamente o paciente a participar de todo o embrolho. Nesse sentido, o acompanhante terapêutico encontra um grande desafio, pois é ele a ponte que possibilita o atravessar do paciente, tanto na ida quanto na volta. E por ter tido a ida é que se faz possível a volta, e nunca se volta da mesma forma como se foi. Safra (2006) em seu artigo sobre o placement enquanto um modelo clínico para o Acompanhamento Terapêutico, aborda a questão do lugar alcançado pelo paciente quando este experencia novas possibilidades de relação com o seu entorno, através de uma vinculação genuína construída entre ele e o acompanhante terapêutico, vislumbrando, deste modo, uma outra qualidade de relação assentada na ética.

Luísa, uma moça beirando os seus trinta anos de idade, pedia durante os atendimentos para ir a lugares distantes de sua casa, dizia buscar algo diferente do que costumava encontrar em seu bairro. Durante certo tempo, esse pedido se sustentou, até o momento em que retrocedeu dizendo preferir ir a lugares mais próximos de sua casa. Estranhando a mudança de seu comportamento procurei entender o porquê de tal pedido, uma vez que em seu processo as solicitações pareciam caminhar no sentido contrário, ou seja, o de ir mais além. Inicialmente, fiquei na dúvida se tal pedido se referia a certa hesitação em seu processo de amadurecimento, no qual é recorrente testemunharmos alguns passos à frente e logo em seguida outros atrás, como bem aponta Winnicott (1958) sobre a hesitação ser, na verdade, ansiedade em relação ao que se anseia conhecer, ou se esse pedido se referia a uma demanda meramente familiar. Foi então que Luísa me explicou que o pedido de ir a lugares mais próximos de casa havia sido feito por seu pai, pois assim gastaria menos combustível no final do mês quando os gastos relativos aos atendimentos eram repassados a ele. Algo naquele discurso parecia não se encaixar, pois até onde tivera notícias, e também nos atendimentos realizados em consultório, o seu pai nunca havia levantado tal questão. Realizei a tentativa de compreender melhor como havia se dado essa conversa entre o pai de Luísa e ela, e para a minha surpresa essa conversa nunca havia existido. Luísa então explicou que, ao sair de casa a sua mãe a orientava a não ir muito longe para não gastar muito combustível. Depois de alguns minutos de conversa a paciente revelou que não havia escutado essa frase propriamente de seu pai, mas que acreditava no que sua 
mãe dizia, ou seja, de que essa era uma orientação de seu pai. Naquele momento, o que eu havia estranhado se confirmara, o pedido não era de seu pai, mas sim de sua mãe que temia que Luísa fosse para muito longe, para muito longe dela. Após esse episódio, tornou-se necessário reunir parte da família em consultório e de forma sutil levantar essa questão para que Luísa e seu pai conversassem a respeito. Na ocasião, - pai de Luísa comunicou claramente que essa nunca havia sido uma orientação/preocupação sua e que a filha poderia ir aonde quisesse, já que o valor do combustível para ele era irrisório. Foi importante estar atenta ao sentimento de estranhamento que me visitou naquele momento, penso que essas situações também ocorrem em consultório, no entanto, o atravessamento desse tipo de situação em casos de Acompanhamento Terapêutico costuma interferir de maneira concreta, impedindo inclusive, como no caso anteriormente descrito, que as saídas ocorram.

A frase "não vá tão longe" escolhida para intitular o presente capítulo é paradigmática e revela algo comum nos casos de Acompanhamento Terapêutico. Não raras são as vezes em que escutamos de alguns pais frases desse tipo como forma de orientação aos filhos antes de saírem de casa: "não se distancie muito", "não vá tão longe", "fique aqui por perto", e etc. Ao mesmo tempo, percebemos que os pacientes encontram nessa orientação um certo bálsamo ao qual se confortam e seguem sem maiores críticas, sentem-se por vezes, aliviados! São falas cotidianas, aparentemente de ordem prática, mas que na verdade revelam um grande receio por parte de alguns familiares, a incluir o próprio paciente, no que diz respeito ao processo de crescimento, (ou melhor seria dizer "nascimento"?). É curioso observar que, precisamente nesse momento do processo, alguns pacientes e famílias parecem recuar diante do trabalho realizado pelo acompanhante terapêutico. A tradição familiar parece entrar em conflito, a nova ameaça uma possível ruptura com o velho e o sentimento de insegurança costuma entrar em cena. Em importante contribuição sobre a presença do acompanhante terapêutico na família do acompanhado, Frank (2017) diz:

A presença de um estranho, muitas vezes não é tolerada pelos sistemas familiares dogmáticos, endogâmicos, onde as verdades transmitidas pelos pais são irrefutáveis, são vividas como perigosas ameaças ao equilíbrio construído, mas pode apontar algo novo tal como uma cunha que introduz algo do mundo exterior. (p.13) 
Algo tão importante quanto a insegurança observada na família, a qual está cristalizada em suas crenças, é também a insegurança que costuma aparecer no paciente quando este se percebe no mundo. Algo próximo de uma euforia que transita entre a alegria e o medo. A experiência nos mostra que não somente a família, como também o paciente, temem o ir mais além dentro do processo de Acompanhamento Terapêutico. Processo este que tem como proposta atravessar fronteiras, sejam elas da casa, do bairro, intrafamiliares e principalmente internas. Essas fronteiras são concretas, mas também simbólicas.

A série televisiva catalã "Merlí" (Lozano, 2015) retrata a vida de um professor de filosofia que utiliza métodos pouco ortodoxos para ensinar os alunos. Um aluno, cujo quadro de agorafobia o impede de estar entre seus colegas no colégio, começa a ter aulas particulares domiciliares com Merlí. É interessante observar que Merlí aplica ao cotidiano do jovem conceitos da filosofia de forma prática e viva, e a meu ver, exerce em alguns momentos funções semelhantes às de um acompanhante terapêutico. No início Ivan, o aluno, nem sequer conseguia abrir a porta de casa para as pessoas, entretanto, aceitou receber o professor. Também não conseguia verbalizar nenhuma palavra, mas depois de certo tempo, por fim arriscou dizer algumas poucas.

Merlí acompanha Ivan tanto dentro quanto fora de casa. A passagem das aulas de dentro de casa para as saídas à rua acontece de forma dramática. A princípio, Merlí sugere apenas quinze passos até a árvore, o suficiente para que seu aluno tenha um ataque de ansiedade. A mãe de Ivan, Miriam, presencia a cena e demite Merlí por não a ter consultado antes de sair com o filho. Merlí aponta que ela está superprotegendo Ivan e que se pudesse deixaria o filho trancado em casa por mais trinta anos, o que obviamente a deixa furiosa.

Em cena posterior, Merlí volta à casa de Ivan e o seguinte diálogo acontece entre ele e a mãe de seu aluno:

Merlí:- Você é o principal problema de Ivan. Tem pena de seu filho. E olha para ele como um bicho esquisito.

Miriam:- Chega, fora daqui!

Merlí:- Eu não tenho pena de Ivan, eu o repreendo, o faço rir e diminuo a importância do ataque de ansiedade que teve na rua.

Miriam:- Acha que é pouca coisa? Vomitou, não consegue respirar. Não consegue sair de casa! 
Merlí:- Até quando? Diga com que idade pretende Ihe dizer para sair?

Miriam:- Ainda é muito cedo!

Merlí:- E você Miriam? Já se olhou? De casa para o bar, do bar para casa. Faz algo mais durante o dia, além de se lamentar e trabalhar? É uma alma penada!

Miriam dá um tapa na cara de Merlí, o qual nem de longe o abala.

Merlí: Você e eu somos a única coisa que Ivan tem, ou os dois somos positivos e confiamos nele ou, dentro de um ano teremos a mesma conversa. Você está isolada, trancada em seu trabalho, mas é uma mulher muito bonita, poderia engolir o mundo. Ivan tem que ver que você se dedica a se cuidar, distraia-se um pouco. Saia, saia! Você também se afoga aqui em casa, libere-se de seu filho. Ivan se sentirá mais forte e Ihe garanto que acabará indo sozinho à escola todos os dias.

Miriam parece ter ficado tocada com as palavras do professor...

Mais à frente, Miriam aparece pensativa e ao passar pelo corredor de seu apartamento começa a se perceber através do vidro de um quadro, acaricia os seus próprios cabelos enquanto olha para o seu reflexo no vidro. Direciona-se até Ivan que está sentado e comunica que Merlí voltará a Ihe dar aulas. O filho fica agitado e diz que não quer sair de casa. Miriam diz que antes eram somente o filho e ela, mas que agora Merlí os está ajudando e que foi Ivan quem o quis como professor. Ivan fica irritado e diz que o queria para estudar dentro de casa e não fora. Nesse momento, a sua mãe o questiona se ele se sente melhor em comparação ao período anterior à chegada de Merlí, Ivan hesita em responder, mas ao final confessa ter melhorado após a chegada do professor. Ao escutar a mãe sorri com os olhos delicadamente. Ivan então, volta a ter aulas com Merlí...

Considero o trecho da série destacado acima emblemático por demonstrar o conflito existente em muitos casos em que o acompanhante terapêutico surge na cena familiar proporcionando o ir mais além do paciente acompanhado. Merlí percebe que, 1) Miriam superprotege Ivan e que não favorece a sua melhora porque na verdade ela também está presa a ele; 2) Miriam deixa de viver a vida para ficar em função do filho e acaba justificando que quem necessita dela é ele 3) sem o incentivo de Miriam Ivan fica prejudicado em seu desenvolvimento e não consegue encarar os seus próprios medos; 4) se Miriam confiar em Ivan ele passará a sentir-se mais seguro e conseguirá retomar o convívio com as pessoas no mundo; 5) Ivan precisaria ver a mãe se cuidando e voltando a viver, para então poder se discriminar dela e com isso também voltar à vida. 
Quando Miriam repensa o seu comportamento em relação ao filho e sugere a ele que Merlí volte, Ivan fica assustado, resiste à ideia de mudança e diz que não quer sair, quer ficar dentro. Interessante observar que no momento em que a mãe aceita a ideia de incentivar o filho, esse último por sua vez recusa a proposta. O que isso quer dizer? Ivan diz querer ficar dentro, dentro de onde? Dentro de casa, dentro de si, dentro de sua mãe...isso aplacaria toda a sua angústia de viver e de conviver com as outras pessoas, em ter que enfrentar a si, seus medos e suas inseguranças. Viver tem um custo, pode ser liberdade, mas também é sofrimento...

Otto Rank (1884-1939) foi um psicanalista e importante teórico que introduziu corajosamente na psicanálise a ideia de que o período intrauterino e posteriormente a ruptura que o nascimento provoca teriam influência sobre os conflitos inconscientes do paciente. Trataremos tal conceito buscando apresentar a ideia de Rank (1924), porém utilizando-a aqui de maneira metafórica ao sugerir que o "nascimento" pode vir a se configurar enquanto possível trauma àqueles que se separam do ambiente simbólico materno (protetor e seguro). Será estabelecido, a partir dessa simbologia do nascimento, um diálogo entre esse fenômeno e a clínica do Acompanhamento Terapêutico. A escolha em utilizar o modelo apresentado por Rank (1924) deu-se tão somente, por testemunhar em minha prática clínica como acompanhante terapêutica, as diversas vezes nas quais os pacientes acompanhados apresentaram dificuldades significativas para se discriminarem do ambiente simbólico materno. Rank foi amigo íntimo de Freud e duramente criticado tanto por ele quanto por grande parte do movimento psicanalítico quando publicou O Trauma do Nascimento, em 1924. Rank "pretendeu concretizar uma discussão - desenvolvida ao longo de quase duas décadas no círculo vienense de psicanálise (...) - acerca do significado simbólico da gravidez." (Rank, 1924, p.13). Para este autor, a fase final de algumas análises, vista por ele como bem-sucedidas, retomavam a importante questão inconsciente do trauma do nascimento vivenciado pelo paciente. Referiu-se ao período pós-análise do paciente como uma espécie de "segundo nascimento". Em sua visão, os pacientes que passavam pelo processo analítico sentiam-se como que "nascidos de novo".

Winnicott (1958), por sua vez, não compartilhava dessa visão sobre todo nascimento se configurar, necessariamente, enquanto trauma. Referia-se ao fenômeno do nascimento como "experiência de nascer" e os diferenciava da seguinte maneira: 1) nascimento saudável; 2) nascimento traumático comum e; 3) nascimento 
traumático extremo. Nesse sentido, acreditava que certas experiências de nascimento poderiam acontecer suavemente, seguindo o curso natural, sendo, portanto, saudáveis ao desenvolvimento do bebê. Sobre a experiência de nascimento traumático, diz: "este é o meu próprio ponto de vista atualmente. Ao contrário, as experiências do nascimento que fogem ao normal além e acima de um certo limite tornam-se traumas do nascimento, e são imensamente significativas. (Winnicott, 1958, p.261). Muito embora Winnicott (1958) reconheça as diversas experiências de nascimento, diferentemente de Rank (1924) que as concebe, necessariamente enquanto trauma psíquico, no presente capítulo não iremos utilizar tal concepção apenas em seu registro psíquico, mas sim e principalmente, em seu sentido metafórico a fim de compreendermos a presença da experiência de "nascimento" dos pacientes acompanhados, tendo tido eles boa experiência, ou não, ao nascerem.

Uma paciente de vinte e oito anos que já estava para completar três anos de acompanhamento queixava-se em consulta de que às vezes se sentia muito exigida. Referia-se ao fato de ter que ligar para algum lugar, pegar ônibus sozinha ou até mesmo entrar em algum site para obter informações. Sempre que sugeria a ela que pudesse dar um passo adiante em seu processo de amadurecimento rechaçava a ideia. Era uma pessoa claramente capaz de realizar atividades sozinha, mas o fato de sentir-se insegura passava muitas vezes pela forma infantil com a qual os seus pais a tratavam. O crescer para essa paciente era algo difícil, ela oscilava entre momentos de rebeldia queixando-se dos pais que a tratavam como criança, para no momento seguinte, assim que eu concordasse com ela, regredir e queixar-se de como se sentia exigida tanto pelos pais, quanto por mim. Não é em vão que nesse pequeno caso acima explicitado menciono o tempo de duração do acompanhamento dessa moça, pois compreendo o Acompanhamento Terapêutico enquanto um processo semelhante ao da gestação, assim como exposto por Rank (1924) em relação à análise. Quando essa paciente resiste à ideia de "caminhar" é porque receia o nascer para além de seu ambiente protegido e seguro, aspira continuar dentro do útero simbólico, no qual a comida é recebida sem que haja nenhum esforço. O pedido da paciente era para que eu ligasse para o local em vez de ela ligar, que eu entrasse no site em vez de ela entrar e que a sua mãe a levasse de carro, às vezes mesmo sem poder, em vez de ela mesma ir de ônibus. Cabe ressaltar que, no começo de seus acompanhamentos todas essas ações eram realizadas por mim (pois entendia a sua 
dificuldade inicial e procurava, de maneira gradativa, tornar aquilo menos assustador), após algum tempo sugeri que fizéssemos juntas e assim por diante até que foi chegado o momento de confiar na paciente e sugerir que fizesse por si mesma, nesse momento ela dizia que eu a estava exigindo muito.

Penso que a modalidade clínica do Acompanhamento Terapêutico também possibilita ao paciente a oferta de uma separação gradual, pois desta forma a separação acontece de forma acompanhada e cuidadosa, no momento em que percebemos que o paciente apresenta condições para alcançar alguma autonomia, ainda que esta seja pequena. É interessante observar que os pacientes mais aderidos à família resistem corajosamente a esse ato de "nascer", parece haver um ganho secundário nisso tudo. "É claro que, por trás de todas essas resistências, o paciente dissimula seu desejo de prolongar infinitamente a situação analítica que tanto o satisfaz. "(Rank, O. 1924, p. 31). Há uma perspectiva em nossa área que muito provavelmente compreenderia esse fenômeno apenas a partir das relações simbióticas (nesse caso, a do filho que não consegue se desvincular da mãe), no entanto, creio que compreender esse fenômeno apenas por este viés reduz algo complexo.

Nesse sentido, penso que a concepção apresentada por Rank (1924), se compreendida de maneira metafórica, auxilia-nos a pensar a questão do "nascer" não somente em termos de organizações psíquicas, mas sim e sobretudo, para além desse registro. Safra (2004) aborda em sua obra a importância de diferenciarmos na clínica os aspectos oriundos do registro ontológico daqueles oriundos do registro ôntico. Creio que o nascer não seja tarefa fácil a nenhum de nós, e por esse motivo parece-me importante diferenciar aquilo que denominarei de "nascimento psíquico", compreendido a partir de um registro ôntico e amplamente abordado por Winnicott, do "nascimento existencial" que se caracteriza enquanto ruptura possibilitando um sentido existencial mais profundo ao ser, também abordado por Winnicott, mas brilhantemente desenvolvido por Safra $(2004 ; 2006 \mathrm{~b})$. Em sua extensa obra, Winnicott demonstra que o bebê se desenvolve em contato com o ambiente. Se o ambiente consegue atender às necessidades singulares do bebê, confere a este a possibilidade de sentir-se real, existente. Todo esse processo inicial refere-se ao que Winnicott denominou de "desenvolvimento emocional primitivo", no qual se alcança a capacidade de ser UM, de sentir-se unidade. Winnicott diferencia em sua obra o inicial 
do profundo. Compreende que há pacientes que não tiveram as condições necessárias para alcançar uma unidade e em outros casos, pacientes que não conseguem funcionar a partir do verdadeiro self, apesar de terem alcançado o mais profundo, o que resulta em uma vida empobrecida emocionalmente. Safra (2006b) por sua vez, amplia a discussão e frisa a importância de se reconhecer na clínica tanto o inicial (abordado por Winnicott), como o profundo característico de conflitos inerentes à castração (inicialmente abordado por Freud), mas também e principalmente, aspectos relativos ao existir singular e autêntico de cada paciente.

Penso também ser importante na clínica do Acompanhamento Terapêutico diferenciarmos o inicial daquilo que é profundo, e o profundo daquilo que é singular/autêntico. Uma moça muito inteligente tinha facilidade para se aprofundar em discussões filosóficas e assuntos complexos, porém não conseguia dar início e muito menos continuidade a tarefas cotidianas. A sua dificuldade encontrava-se no mais simples e no mais inicial, o acompanhamento se dava em situações que envolviam desde a sua alimentação até o estar junto em situações que sozinha não conseguia sustentar. Nesse caso, o acompanhamento precisava atender às suas demandas mais iniciais e, portanto, primitivas. É interessante observar que há pessoas com grande capacidade de articular pensamentos e reconhecer aspectos inconscientes de si, transitando no mais profundo, muito embora não consigam fazer frente a situações cotidianas corriqueiras. Outras não alcançaram nem o profundo e nem o inicial, e assim por diante. Em minha experiência observei muitas vezes a dificuldade, seja de quem alcançou o mais profundo ou não, assim como quem alcançou o inicial, ou até mesmo antes de chegar a ele, um movimento de retornar ao estágio anterior. Isso acontecia em momentos de medo em relação ao novo, o que fazia com que muitos pacientes ficassem regredidos em determinado momento do processo.

O desafio de "nascer" nesse sentido parece estar presente também na maioria dos casos de Acompanhamento Terapêutico, seja naqueles em que acompanhamos os pacientes com necessidades mais primitivas rumo à integração do self (nascimento psíquico), bem como àqueles que já se organizaram de forma mais integrada e já alcançaram o profundo ansiando pelo ser autêntico no mundo (nascer existencial).

Ademais, compreendo também que dentro e a partir dessa concepção o nascer mais profundo pode acontecer até o momento final da vida e independentemente da 
idade. É preciso estar aberto ao nascer todos os dias, e para que isso aconteça, haja combustível... 


\subsection{Acompanhamento Terapêutico e Família: o ódio na contratransferência}

O correr da vida embrulha tudo. $A$ vida é assim: esquenta e esfria, aperta e daí afrouxa,

sossega e depois desinquieta. O que ela quer da gente é coragem.

(Rosa, p.334,1956)

Inicio este capítulo com uma frase de Guimarães Rosa, por acreditar que para odiar é preciso coragem. É justamente nesse vaivém da vida descrito pelo autor que o ódio se encontra presente. Barretto (1997) denomina o Acompanhamento Terapêutico como a clínica do cotidiano. Mendonça (2014) lança o seu primeiro livro, intitulado Acompañamiento Terapeutico y clinica de lo cotidiano. Quem de nós, acompanhantes terapêuticos, nunca sentiu em um atendimento exatamente o que Guimarães Rosa descreve? Como já dito anteriormente, a clínica do Acompanhamento Terapêutico não acontece no cotidiano somente, ela é o próprio cotidiano, isso a constitui. Se o Acompanhamento Terapêutico se caracteriza por ser a clínica do cotidiano, visão com a qual concordo, é esperado que façam parte dela todos os sentimentos inerentes à vida, o que incluí o ódio. Compreendo o ódio não como uma entidade, mas como uma indicação de que a vida está em movimento, acontecendo em sua magnitude.

A escolha em iniciar esse capítulo, abordando o conceito de ódio em vez de abordar o conceito de contratransferência, não sem motivo, deu-se por considerar a importância de discutirmos esse tema na clínica do Acompanhamento Terapêutico. Essa opção sinaliza a importância de nos atentarmos ao ódio, como um dentre tantos outros sentimentos experimentados por nós, analistas e acompanhantes terapêuticos, mas que, a meu ver, carrega uma importância em relação aos outros, por ser pouco abordado em nossa área. O que significa o silenciar sobre o ódio em nossa área? Parece tabu...

Penso ser importante aprofundarmos o tema do ódio na contratransferência, em especial, no que concerne às famílias dos pacientes acompanhados por ser algo que testemunhamos recorrentemente, em nossa prática clínica. Winnicott (1958), corajosamente, introduziu no campo psicanalítico a discussão do ódio na 
contratransferência, alertando-nos sobre a presença desse sentimento no analista que atende pacientes psicóticos e com tendência antissocial. Advertiu sobre a possibilidade de o ódio no analista indicar a necessidade de mais análise pessoal, uma vez que em análise são trabalhados os "reservatórios de ódio inconsciente pertencentes ao seu passado e a conflitos internos" (Winnicott, 1958, p.344). No entanto, a sua brilhante contribuição adveio do fato de constatar que o ódio contratransferencial está atrelado ao atendimento de certos pacientes, os quais exigem do analista uma devoção para atender a demandas ainda muito primitivas do desenvolvimento emocional. Segundo Winnicott (1958), o ódio no analista está sempre presente, muito embora o esteja de forma latente nas análises comuns, diferentemente dos casos de análise de pacientes psicóticos e antissociais, os quais necessitam viver outro tipo de relação transferencial com o analista. Segundo ele, nestas últimas situações "a tensão que recai sobre o analista difere bastante em tipo e grau" (Winnicott, 1958, p. 345). E adverte-nos:

Se queremos ser capazes de analisar pacientes psicóticos, é necessário termos chegado às coisas muito primitivas dentro de nós mesmos, o que mais uma vez ilustra o fato de que muitos problemas obscuros da prática psicanalítica podem ser solucionados com uma maior análise do analista. (Winnicott, 1958, p.343)

Segundo Winnicott (1958), a análise de pacientes psicóticos exige do analista um maior esforço "para manter o seu ódio latente, só conseguindo fazê-lo, se estiver completamente consciente do próprio ódio" (p.348). Em minha experiência clínica, pude constatar diversas vezes a presença do ódio não somente em relação ao paciente, pela natureza de seu adoecimento e exigência transferencial, como também em relação às famílias que se encontravam em um grave sofrimento psíquico e que exigiam de mim grande capacidade de tolerar, esperar e compreender.

Recordo-me de Ricardo, um homem de meia idade que já estava há alguns meses sendo atendido: pedia-me para não ter contato com sua família, dizia que tudo o que a envolvesse certamente traria problemas e viraria uma confusão, e que, portanto, preferiria manter a nossa relação preservada nesse sentido. Morava sozinho e certo dia pediu-me que fosse com ele até a casa de sua mãe, para entregar um cheque. Naquele momento, entendi o pedido como algo corriqueiro e sem maiores intenções. Ao chegarmos à casa da família, presenciei uma cena que logo me fez 
entender o motivo pelo qual o paciente havia me pedido para acompanhá-lo. Assim que chegamos, sentamos à mesa, mãe e filho começaram a conversar. Tudo parecia caminhar bem, até que Ricardo sutilmente discordou de sua mãe em um assunto aleatório. Foi então que escutou: "nunca mais diga isso! Você quer levar um tapa nessa cara?" (sic), disse a mãe de maneira agressiva e intimidadora. O paciente agiu como uma criança assustada e pediu desculpas à mãe. Eu fiquei espantada ao presenciar aquilo! Ricardo nem sequer havia afrontado a mãe, apenas discordara em um assunto qualquer e ainda de maneira banal. Assim que Ricardo comunicou que iríamos embora, sua mãe me pediu para ir ao andar de cima conhecer o marido, que estava acamado e que, segundo ela, encontrava-se bastante deprimido. No caminho pediu ainda que eu o atendesse, pois se o atendimento estava fazendo bem ao filho, certamente faria a seu marido também. Conheci o pai do paciente, agradeci pela confiança e disse que não costumava atender mais de um membro da família; coloquei-me à disposição para indicar outro profissional, caso assim o quisessem. No caminho de volta eu e o paciente pudemos conversar sobre o ocorrido, foi então que ela disse: "sempre que conto da minha família para as pessoas, elas me acham mentiroso. Você viu como é?" (sic). Entendi, naquele momento, que ele precisava de alguém de fora de sua família que testemunhasse a loucura familiar, e que lhe devolvesse em forma de teste de realidade a percepção da violência ali ocorrida. Esse paciente, em específico, nunca sabia ao certo se a sua percepção sobre as coisas e as pessoas era real ou enlouquecida. Com o tempo foi preciso ir legitimando toda a sua percepção em relação às situações vivenciadas, e aos poucos ele foi podendo confiar mais em si mesmo e em sua percepção sobre as coisas.

Destaco essa passagem, pois no momento em que a mãe do paciente enunciou a referida frase, fui tomada por um sentimento de ódio! Fiquei espantada com tamanha agressividade. Creio que uma atuação (acting-out) em uma ocasião como aquela, seria o acompanhante terapêutico entrar em cena, defendendo a paciente ou recriminando a mãe por ter sido agressiva com o filho. Não foi esse o meu posicionamento, muito embora essa fosse a minha vontade. Contive o meu próprio ódio.

Durante a presente pesquisa, surpreendi-me com o fato de encontrar muito mais espaço de diálogo entre os colegas/alunos do Departamento de Psicologia Social do que do Departamento de Psicologia Clínica para discutir o fenômeno do ódio 
na contratransferência (Winnicott, 1957). Curiosamente, as pessoas com as quais dialogava na Psicologia Social pareciam muito mais abertas e sensíveis à violência e/ou injustiças, seja de que natureza fossem, do que as pessoas do Departamento de Psicologia Clínica. O que isso quer dizer? Conheci durante a disciplina de Metodologia de Pesquisa em Psicologia Social, ministrada pelos professores Alessandro Santos, Gustavo Massola e Luis Galeão, o pesquisador Martin Baró, proponente da Psicologia da Libertação. Baró dedicou-se ao estudo das diversas formas de violência e lutava para alcançar condições de transformação social. Apesar de não ser psicanalista, neste pequeno trecho de sua obra refere-se ao fenômeno da contratransferência:

\begin{abstract}
O fenômeno da contratransferência, que Freud descobriu no processo analítico, não é exclusivo da psicoterapia. Além disso, eticamente não podemos deixar de tomar posição diante de muitos fenômenos. Porém, e esse é o ponto que desejo sublinhar: a parcialidade que sempre se supõe de uma tomada de posição não tem por que eliminar a objetividade. É um absurdo e uma aberração pedir imparcialidade aos que estudam a drogadicção, o abuso infantil ou a tortura. $O$ que se pode e se deve exigir é que tais fenômenos sejam analisados com todo o rigor e com abertura total aos dados da realidade. Isto é, a objetividade não é o mesmo que a imparcialidade. Todavia, a opção axiológica que leva a rechaçar certas coisas e a desejar outras deve ser sempre um horizonte que ilumina o nosso fazer (quehacer) e isso não como algo complementar, mas como algo intrínseco à própria atividade científica, acadêmica ou profissional (p.209-210)
\end{abstract}

Baró (2011), portanto, problematiza a questão da imparcialidade frente a situações que, inexoravelmente, exigem um posicionamento por parte do pesquisador. É interessante pensarmos, na clínica do Acompanhamento Terapêutico, sobre a reação que temos ao presenciar situações que envolvam violência e/ou injustiças em relação ao paciente. Penso que a percepção sobre essas situações, muitas vezes, precisa ser comunicada ao acompanhado, a fim de autorizar e legitimar a dor/violência infligida. O sentir do acompanhante terapêutico, a meu ver, parece uma questão de fundamental importância a ser considerada, já que nos atendimentos ele está frequentemente sujeito a testemunhar sofrimentos diversos e oriundos desses fenômenos.

Paula Heimann (1899-1982), psicanalista da Sociedade Britânica de Psicanálise, apresentou um importante artigo problematizando o conceito de contratransferência, dizendo: 
Muitos candidatos sentem temor e culpa quando se conscientizam dos sentimentos que nutrem em relação a seus pacientes e, por consequência, pretendem evitar qualquer resposta emocional de sua parte, e tornam-se completamente insensíveis e "imparciais". (Heimann, 1949, p.15)

Destaco esse trecho, fundamentalmente importante, pelo fato de ter sido uma mulher a responsável por levar a questão do sentir do analista à sociedade psicanalítica da época, a qual era exercida, majoritariamente, por analistas homens. Freud (1910) advertia os analistas (homens) contra qualquer contratransferência que pudesse estar em suas mentes. Segundo ele, a contratransferência era um obstáculo que impedia o andamento satisfatório do processo de análise. Em Observações sobre o amor transferencial - novas recomendações sobre a técnica da Psicanálise, Freud (1915) relaciona o fenômeno da contratransferência ao fenômeno da transferência erótica, evidenciando, assim, uma ética de cuidado na condução do processo analítico de suas pacientes, advertindo os analistas de sua época:

Ele deve reconhecer que o enamoramento da paciente é induzido pela
situação analítica e não deve ser atribuído aos encantos de sua própria
pessoa; de maneira que não tem nenhum motivo para orgulhar-se de tal
"conquista", como seria chamada fora da análise. E é sempre bom lembrar-
se disto. Para a paciente, contudo, há duas alternativas; abandonar o
tratamento psicanalítico ou aceitar enamorar-se de seu médico como um
destino inelutável. (Freud, 1910, p.122)

Parece-me importante contextualizar uma possível origem do silenciamento do sentir do analista em nossa prática clínica, pois a meu ver, esses são fatos que possivelmente interferem na maneira como concebemos o ódio contratransferencial na prática clínica do Acompanhamento Terapêutico. Barretto (1998) assinala sobre a importante intervenção de uma acompanhante terapêutica, quando reconhece em si mesma um sentimento de confusão originado pela confusão mental de seu paciente, a partir do qual comunica a sua angústia ao paciente, transformando o que antes era confusão em encontro sensível:

Confesso que naquele momento nada entendia. Desanimada, digo: 'Que confusão, quanta mistura: pessoa, coletivo, parede. Será que não foi isso que te impediu de dormir?' Põe-se a coçar os olhos e, subitamente, me dou conta de que chora. Do meu lado, se é que nesses momentos existem lados claramente definidos, me emociono e me assusto. Numa tentativa de dar nome a este sentimento, pergunto se o que 'bateu' foi tristeza. José se levanta e, numa mistura de riso e choro, esclarece: 'É que estou sentindo a alma'. (p.74) 
A partir dessa vinheta clínica, o autor analisa a função continente do acompanhante terapêutico no contato com o paciente, nesse caso: a capacidade em ter contido em si a angústia e confusão do paciente, para logo em seguida devolver em forma de intervenção. Penso que esse modelo de compreensão do sentir do acompanhante terapêutico em relação ao acompanhado pode ser também utilizado para compreender os sentimentos contratransferenciais do acompanhante terapêutico em relação à família do acompanhado.

Uma moça encontrava-se em estado depressivo e só saía de seu quarto nos atendimentos. A queixa da família referia-se justamente a esse isolamento por parte da paciente. No entanto, no contato mais próximo e íntimo comigo, não era isso o que se observara: a paciente conversava bastante e dizia tanto sobre os seus sentimentos em relação às pessoas, como sobre seus pensamentos em relação à vida. Certa vez, encontrei-me com sua tia (pessoa responsável por cuidar dela) no portão do quintal de sua casa e em menos de cinco minutos senti vontade de sair correndo, por assim dizer: o modo como ela falava e as perguntas que me fazia fizeram com que me sentisse extremamente invadida. Naquele momento, eu entendi por que a paciente precisava manter todas as suas coisas a sete chaves (queixa da família); havia uma necessidade de preservar sua privacidade, o contrário disso colocá-la-ia em risco iminente de ser invadida pelo outro. A partir do evento, entendi profundamente a queixa da paciente em relação à tia, senti e carreguei comigo a sensação todas as vezes que conversávamos sobre o assunto. Penso que essa função exercida pelo acompanhante terapêutico se assemelha à função exercida pelos guardiões que zelam por algo realmente valioso.

Santos (2013) refere-se aos sentimentos contratransferenciais do acompanhante terapêutico em relação à família do acompanhado e questiona: "há algum at que já não teve raiva dos familiares do seu paciente?" (p.199). Considero esse questionamento fundamentalmente importante para diferenciarmos o sentimento de raiva do sentimento de ódio. Acredito que o sentimento da família pelo acompanhante terapêutico se aproximaria mais da raiva do que do ódio. A minha hipótese é a de que o sentimento de raiva dos familiares em relação ao acompanhante está relacionado diametralmente ao estabelecimento de um lugar (Safra, 2006). O filme Escritores da Liberdade (Lagravenese, 2007), a meu ver, aborda de maneira brilhante e impecável essa questão. Abaixo um resumo da história: 
Erin Gruwell é uma professora principiante que assume uma classe de alunos considerados "problemáticos". A princípio, tenta ensinar a matéria por um método ortodoxo, porém com o tempo percebe que tal modelo não desperta o interesse de seus alunos, o que a faz buscar novas formas de ensinar. Aos poucos, percebe a importância de compreender a difícil realidade que vivem, arrisca aproximações e, a partir disso, começa a estabelecer uma comunicação significativa com seus alunos. Eles, por sua vez, após muitas resistências, percebem o investimento emocional da professora e o esforço que faz para dialogar, respeitando sempre a singularidade de cada um deles. Isso os aproxima genuinamente, até o ponto em que os alunos começam a estabelecer um sentimento de confiança pela professora. Em dado momento, ela tem a brilhante ideia de presenteá-los com diários em branco, colocando-os em um armário e deixando à disposição caso queiram escrever. Em seguida, explica que irá deixar o armário aberto e ao final do expediente recolherá todos os diários para acompanhar o que escreveram. Assim que Erin Gruwell abre o armário, tem a grata surpresa de encontrar muitos diários. Por meio deles, os alunos começam a compartilhar suas próprias histórias, sempre precedidas de muito sofrimento. A proximidade entre professora e alunos é cada vez maior, eles sentemse reconhecidos, compreendidos e, principalmente, vistos pela nova professora. Ela claramente oferta a cada um deles um lugar. Um lugar no mundo, pois os respeita e os trata com dignidade, diferentemente dos outros professores. Um lugar dentro dela, pois os leva dentro de si aonde quer que vá, inclusive após o expediente, preparando atividades para o dia seguinte. Um lugar no futuro, pois é a única que os olha com olhos de esperança, acreditando, até mesmo mais do que eles próprios, no merecimento que cada um tem de um amanhã melhor. Enquanto essa bonita relação acontece entre professora e alunos, o incômodo entre os professores e a direção da escola começa a surgir, todos se sentem incomodados.

Esse filme, a meu ver, apresenta situações paradigmáticas quando comparadas à clínica do Acompanhamento Terapêutico. A raiva e o incômodo sentidos pela diretora Margaret são similares, no meu entendimento, à raiva e ao incômodo sentidos pelos familiares quando finalmente há o estabelecimento de um vínculo significativo entre paciente e acompanhante terapêutico. Margaret fica ressentida por ver Gruwell estabelecer vínculos genuínos com os alunos. Sente-se enciumada, no entanto, nunca apresentou disposição para investir neles da mesma 
forma que a senhora Gruweel. Enquanto a professora buscava novas formas para incentivá-los, a diretora os desqualificava, resistindo a qualquer tipo de investimento. O ápice do filme acontece quando a turma de alunos toma conhecimento de que no ano seguinte a professora Gruwell não os acompanhará mais. Ficam desolados e indignados. Uma das alunas diz:

- Esse é o nosso porto-seguro, é o único LUGAR que podemos ser nós mesmos, não tem nenhum LUGAR como esse para a gente lá fora!

A aluna reconhece a oferta de lugar! A professora, então, informa que não se trata de uma escolha, mas sim de uma regra institucional. Os alunos se mobilizam para que a senhora Gruweel continue a Ihes dar aulas. A diretoria de ensino é acionada e a professora explica à pessoa responsável o motivo pelo qual gostaria de continuar com a turma:

Professora Gruwell: - Esses alunos, essa turma é como se fosse uma família...

Diretora Margaret: - Para quem? Para você?

Professora Gruwell: - Uns pros outros! A sala 203 se transformou na casa deles, a confiança deles se baseia em estarmos juntos como um grupo.

Os alunos passaram a ter aquela sala de aula como um lar, ali estudavam, alimentavam-se, conversavam, descansavam e se apoiavam. Aquele lugar passou a ser uma referência para eles, lugar constituído! Após a mobilização, os alunos conseguem que a professora continue a acompanhá-los. A história do filme é verídica; Escritores da Liberdade foi baseado no livro de mesmo nome, o qual foi escrito em conjunto por todos os alunos que compartilharam as suas histórias sob incentivo da professora Gruwell.

Esse foi o panorama apresentado para estabelecer um paralelo entre a família do acompanhado (diretora Margaret) e a figura do acompanhante terapêutico (senhora Gruwell), demonstrando, assim, os impasses vivenciados pelo acompanhante terapêutico no contato com a família do acompanhado, bem como a presença do sentimento de raiva experenciado e que concerne à realização de seu trabalho. No entanto, a meu ver, o ódio pode ser considerado a partir de outra perspectiva, diferente da apresentada em relação à raiva: 
a) a primeira estaria relacionada à concepção de Winnicott (1958) acerca da sobrecarga emocional sentida pelo analista/acompanhante terapêtico no trabalho com pacientes e/ou famílias muito demandantes.

b) a segunda refere-se a situações de violência presenciadas pelo acompanhante e que despertam nele um grande e intenso incômodo. Essas dizem respeito a algo mais profundo.

Safra (2006b), em A Hermenêutica na situação clínica, apresenta a partir de sua experiência clínica a importante concepção do que denominou de idioma pessoal, o qual está estreitamente atrelado ao conceito de sagrado em sua clínica. Recorro a esse importante conceito por considerar que o ódio de cada analista/acompanhante terapêutico revela o sagrado nele e para ele. Creio que cada profissional carrega em si núcleos que são acionados e que revelam sua pessoalidade. Compreendo que isso não se configuraria como um problema a priori, pois o contrário disso seria negar aquilo que somos. Entendo que o problema estaria em não manejar esse sentimento a favor do processo terapêutico do paciente. Considero importante destacar essa diferença, pois não se trata aqui de negar o ódio sentido, mas sim, como propõe Winnicott (1958), de reconhecê-lo, a fim de mantê-lo latente para uso objetivo posterior, se for o caso.

No livro Ansiedades psicóticas e prevenção: registro pessoal de uma análise com Winnicott (Little, 1992), Margaret Little narra passagens significativas de sua análise com Winnicott. A célebre frase do psicanalista inglês: "eu realmente odeio a sua mãe" (p.48) autoriza o sentir do analista e a possibilidade de comunicação dos sentimentos contratransferenciais ao paciente. Essa frase foi dita por ele após constatar que o impedimento de Little em chorar tinha origem em um dia que, ao chorar por sentir muita dor de dente, sua mãe lhe disse: "pare de chorar, querida, você faz todos se sentirem péssimos" (Little, 1992, p.48). Penso que esse primeiro recorte da análise de Little serve-nos como modelo paradigmático para também pensar o ódio na contratransferência com a família do paciente acompanhado. Recordo-me de um caso no qual a paciente aguardou longos meses até conseguir vaga em uma atividade muito desejada por ela. No primeiro dia pediu que eu a acompanhasse e também que a esperasse até o final da atividade. Fiquei de longe olhando-a e acompanhando as atividades de seu primeiro dia de curso. Fiquei tão emocionada em ver a felicidade dela que umas lágrimas caíram de meus olhos, tentei disfarçar. Ao chegar em casa, 
alegre e animada foi em direção ao pai contar sobre o seu primeiro dia de curso. Ele, além de ter dado as costas, disse: "grande coisa!" (sic).

Mendonça (2017) em recente e importante contribuição ao campo do Acompanhamento Terapêutico destrinchou as vicissitudes transferenciais e contratransferenciais desta clínica, denominando de transferência familiar o modelo de relação estabelecido pela família que:

(...) consiste em relacionar-se com o Acompanhante como se ele fosse 0 paciente; de modo que no decorrer de seu trabalho, uma ou outra vez o acompanhante receberá as investidas do excesso materno. Sobretudo nos Acompanhamentos longos, não é equivocado dizer que se chega a experimentar "na própria carne" os processos vinculares que conduziram à psicotização e à cronicidade do paciente. (p.138)

Segundo Mendonça (2017), as manifestações interativas da chamada transferência familiar ocorrem da seguinte forma:

\begin{abstract}
1) A figura materna tende a impor uma série de mandatos e exigências com a finalidade de que o acompanhante atue segundo os critérios do excesso materno e, assim, se coloque em sua 'área de controle emocional onipotente' (Winnicott); 2) Por sua vez, tais padrões interativos tendem a pôr o acompanhante no (não) lugar da figura paterna excluída, anulada e subordinada aos mandatos maternos; ou seja, no (não) lugar de 'assistente' passivo do excesso materno. (pp.137-138)
\end{abstract}

De maneira brilhante, Mendonça (2017) apresenta o que chama de paradoxo contratransferencial, ao sugerir que o acompanhante terapêutico atue de maneira negativa para conseguir um efeito positivo. De acordo com o autor, o acompanhante terapêutico que não se molda inicialmente à organização familiar tende a encontrar resistências em seu trabalho, o que conduz muitas vezes a interrupção do tratamento por parte da família. Por outro lado, se o acompanhante terapêutico cede às exigências familiares sem com isso promover mudança alguma, apenas adere e não realiza o seu trabalho. Foi a partir dessa idiossincrasia característica da clínica do Acompanhamento Terapêutico, que Mendonça pensou em um modelo de atuação por parte do acompanhante capaz de contemplar esse paradoxo.

Segundo Mendonça (2017) o acompanhante terapêutico deve inicialmente se moldar à organização familiar e aos poucos ir demarcando espaço nas intervenções que devem, segundo ele, ocorrer de maneira gradativa. O ódio contratransferencial nesse sentido, deve ser contido, a fim de dar espaço às exigências familiares em um 
primeiro momento. No entanto, é importante que o acompanhante terapêutico não se perca nesse movimento e consiga recuperar o motivo pelo qual acompanha o seu paciente. Com a confiança estabelecida, a partir do que denominou de transferência familiar, o acompanhante terapêutico passa então a "ganhar" espaço e introduzir aos poucos pequenas alterações no setting de atendimento.

Outra perspectiva apontada pelo autor relaciona-se ao fato de o acompanhante terapêutico sustentar uma atitude que se aparente de alguma maneira ao que é o funcionamento próprio da família. Segundo ele, uma família com organização interna precária dificilmente suportaria um acompanhante terapêutico com postura madura demais, isso o tornaria um elemento perturbador à família. Nesse sentido, Mendonça (2017) sugere que o acompanhante terapêutico tenha alguma abertura para se moldar ao funcionamento familiar, sustentando sempre uma atitude baseada no paradoxo contratransferencial: ora ocupando o lugar que a família o coloca, ainda que esse seja o lugar de paciente (excesso materno), ora saindo desse lugar que a família o colocou para ir se discriminando de maneira gradativa. Esse movimento, inclusive, favorece o processo de identificação do paciente com o acompanhante terapêutico, uma vez que, assim como o paciente o acompanhante em alguns momentos participa da dinâmica familiar e em outro se discrimina dela, sem com isso deixar de integrar e fazer parte da mesma. 


\section{Capítulo 5 - Considerações finais}

Procurou-se na presente pesquisa levantar considerações acerca da presença familiar na clínica do Acompanhamento Terapêutico. Como apontado no decorrer desta dissertação, são as vicissitudes dessa prática clínica que sugerem a importância de problematizar o lugar da família na clínica do Acompanhamento Terapêutico. O método utilizado buscou estar em consonância com as particularidades dessa modalidade de atendimento, de tal forma que contemplasse os fundamentos paradoxais inerentes às suas especificidades.

A maneira como a família se organiza (ou desorganiza) em torno do Acompanhamento Terapêutico sinaliza uma demanda para além do paciente acompanhado, incluir a família chega a ser quase um pleonasmo, pois ela está presente, quer queira o acompanhante, quer não, de diversas formas e em variadas dimensões. A proximidade não só com o paciente como com a sua família, idiossincrasia desta modalidade clínica, exige de nós acompanhantes terapêuticos espaços para discussão do tema, dada a intensidade contratransferencial característica desses casos. Considerar o sofrimento presente em todos os envolvidos devolve à família como um todo o cuidado em forma de comunidade de destino.

Como em todo trabalho acadêmico há uma decisão importante quanto ao recorte feito em relação ao tema pesquisado. Algumas escolhas representam recortes que ilustram as dificuldades encontradas a partir de minha experiência clínica. Não foi a intenção desta pesquisa apresentar possibilidades de intervenção sistematizadas, mas sim, a de compartilhar possíveis dificuldades inerentes ao trabalho do acompanhante terapêutico no contato com as famílias acompanhadas, além de apontamentos iniciais que desvelam um horizonte de possibilidades de cuidado, tais como a apresentada no subcapítulo 3 , o qual trata sobre a abertura ao inédito, bem como no subcapítulo 4.2 o qual aborda a importância do gesto, ambos como possibilidades de manejo.

O processo de escrita desta dissertação conferiu uma experiência inusitada, a saber, a de revisão de minha própria prática clínica. Durante esse processo, conforme a escrita se desenvolvia sentia-me como que questionando a minha própria compreensão do que ali havia acabado de transmitir. Ao reler alguns trechos do texto, aspectos que antes não haviam sido contemplados começaram a existir em meu 
horizonte de reflexão. Como muitos desses aspectos, a meu ver, ainda precisariam de amadurecimento, decidi por não os apresentar ainda nesse incipiente trabalho. Ainda há muito o que se contribuir no que diz respeito ao tema proposto desta dissertação, nesse sentido, penso que a comunidade científica interessada no tema tem muito ainda a contribuir na problematização e expansão desse tema, o qual carrega fundamental importância rumo ao avanço da construção teórico-clínica no campo do Acompanhamento Terapêutico.

Algo importante de salientar é que a experiência apresentada e descrita neste trabalho partiu de minha experiência clínica na área de Saúde Mental. O que isso quer dizer? Que as reflexões apresentadas partem de uma clínica muito específica. Muito do que foi discutido não se enquadra, por exemplo, em minha embrionária experiência de Acompanhamento Terapêutico, por exemplo, no campo do judiciário. Algumas vezes, sim, mas na maioria das vezes, não. A prática clínica baseada em casos encaminhados pela Vara da Família tem apresentado uma outra perspectiva que indica para novas reflexões de manejo com as famílias acompanhadas no processo de Acompanhamento Terapêutico. Trata-se de casos de litígio, os quais exigem do acompanhante terapêutico um manejo muito específico com as famílias acompanhadas. Essa experiência não foi exposta nesta dissertação, podendo ser explorada quiçá, em trabalhos futuros, dada a pertinência do assunto para o tema "Família e Acompanhamento Terapêutico".

Pretendeu-se, portanto, com a presente pesquisa abrir caminho para novas discussões acerca da presença familiar na clínica do Acompanhamento Terapêutico, seja no âmbito da saúde mental, ou em outros como mencionado anteriormente. A partir dessa contribuição, espera-se que novos desdobramentos sejam alcançados pela comunidade científica interessada no tema. 


\section{Referências Bibliográficas}

ANDORNO, S. N. Resistências familiares al dispositivo de A.T. Trabalho apresentado no VII Congreso Internacional de Acompañamiento Terapéutico, México, 2013.

ANTÚNEZ, A. E. A. Perspectivas fenomenológicas em atendimentos clínicos: humanologia. Tese de Livre Docência, Instituto de Psicologia, Universidade de São Paulo. São Paulo, 2012.

BALDUINO, R. C; DENAME, D; TEIXEIRA, A. P. A. A rua como espaço clínico: acompanhamento terapêutico. Equipe de Acompanhantes Terapêuticos do Hospital Dia "A CASA". São Paulo: Escuta, 1991.

BARÓ, I. M. A contribuição social da Psicologia na América Latina. In. Psicologia Social - Para a América Latina. O Resgate da Psicologia da Libertação. Desafios e Perspectivas da Psicologia Latino-Americana. Editora Alínea, 2011.

BARRETTO, Kleber Duarte. Acompanhamento Terapêutico: uma clínica do cotidiano. Insight: Psicoterapia, São Paulo, Lemos Editorial, ano VII, n. 73, p. 22-24, maio/1997.

BARRETTO, K. D. (1998). Ética e técnica no Acompanhamento Terapêutico. Andanças com Dom Quixote e Sancho Pança. 3á Ed. São Paulo. Edições Sobornost, 2005.

BATESON, G. Doble Vinculo y Esquizofrenia (El síndrome y sus factores patogénicos interpersonales). Buenos Aires: Ediciones Carlos Lohle, 1972.

BELLO, A. A. Introdução à Fenomenologia. Bauru: São Paulo : UDUSC. 2006

BOCK, A. M. B. e cols. Psicologias: uma introdução ao estudo da psicologia. 14a ed. São Paulo: Saraiva, 2008.

BRASIL, MINISTÉRIO DA SAÚDE. Resolução 196/96 do Conselho Nacional de Saúde/MS Sobre Diretrizes e Normas Regulamentadoras de Pesquisa envolvendo seres humanos. Diário Oficial da União, 10 de outubro de 1996. 
BREST, M. Perfume de mulher. Produção cinematográfica. Estados Unidos: Universal Pictures, 1992.

BRIAN, B. La inclusión y la familia en el dispositivo del acompañamiento terapéutico. Trabalho apresentado no XI Congresso Internacional de Acompanhamento Terapêutico. São Paulo, 2017.

BOLLAS, C. A sombra do objeto: psicanálise do conhecido não-pensado. Imago: Rio de Janeiro, 1992.

CARVALHO, S. S. Acompanhamento Terapêutico: que clínica é essa? São Paulo: Annablume, 2004.

DETHIVILLE, L. Um objeto transicional chamado família. XVIII Colóquio Winnicott de São Paulo. Centro Winnicott de São Paulo, 2013.

DRAGOTTO, P. y FRANK, M. (2012). Acompañantes. Conceptualizaciones y Experiencias en AT. Córdoba, Argentina: Editorial Brujas, 2012.

DRESCH, A. Métodos de Pesquisa. Desing Science Research. Porto Alegre: Editora Bookman, 1998.

FARIA, M. R. Introdução à psicanálise de crianças: o lugar dos pais. São Paulo: Editora Toro, 2016.

FILHO, J. G. T. C. A acepção de família na teoria psicanalítica: Sigmund Freud, Melanie Klein e Jacques Lacan. Tese de mestrado defendida pelo autor no PPGPSIUFSJ. São João Del Rei: 2010.

FRANK, M. L; COSTA, M; HERNÁNDEZ, D. Acompañamiento Terapéutico: clínica en las fronteras. Córdoba, Argentina: Brujas, 2016.

FRANK, M. L. Algunas reflexiones sobre la Familia y el Acompañamiento Terapéutico. Revista de Acompanhamento Terapêutico ATRAVESSAR, №3. São Paulo: Editora Dobro Universitario, 2013.

FRANK, M. L. La presencia en el acompañamiento terapéutico: efectos e incertidumbres. Trabalho apresentado no XI Congresso Internacional de 
Acompanhamento Terapêutico, XII Congresso Ibero-americano de Acompanhamento Terapêutico. São Paulo: UNIFESP. 2017

FREUD, S. A história do Movimento Psicanalítico, Artigos sobre a Metapsicologia e outros trabalhos. Edição Standard Brasileira das Obras Psicológicas Completas de Sigmund Freud. Vol XIV. (1914-1916). Rio de Janeiro: Imago, 2006.

Volume XI. Capítulo 5. (1910). As perspectivas futuras da terapêutica psicanalítica. Edição Standard Brasileira das Obras Psicológicas Completas de Sigmund Freud. Rio de Janeiro: Imago, 2006.

(1915) - Observações sobre o amor transferencial (novas recomendações sobre a técnica da Psicanálise III)

GALARD, J. A Beleza do Gesto: uma estética das condutas. São Paulo: EDUSP, 1997.

GOMES, I. C. Clínica Psicanalítica de Casal e Família. São Paulo: Santos Editora, 2009.

LISPECTOR, C. Correspondências. Rio de Janeiro: Rocco, 2002.

LOZANO, H. Merlí. Dir. Eduard Cortés. Série Televisiva. Cataluña: TV3, 2015.

MACHADO, R. Trabajo en equipo y Acompañamiento Terapéutico Escolar. Módulo Especialización en "Acompañamiento Terapéutico Escolar con niños y adolescentes". Córdoba, Argentina, 2015.

MAUER, S.; RESNISKY, S. Acompanhantes Terapêuticos e Pacientes Psicóticos: manual introdutório a uma estratégia cínica. Campinas, São Paulo: Papirus, 1987.

MAUER, S.; RESNISKY, S. Acompanhantes Terapêuticos: atualização teóricoclínica. Buenos Aires, Argentina: Letra Viva, 2008.

MAUER, S.; RESNISKY, S. Territórios do Acompanhamento Terapêutico. Buenos Aires, Argentina: Letra Viva, 2009. 
MAUER, S.; RESNISKY, S. El Acompañamiento Terapéutico como dispositivo. Buenos Aires, Argentina: Letra Viva, 2011.

MENDONÇA, L. D. Acompañamiento Terapéutico y clínica de lo cotidiano. Beunos Aires: Letra Viva, 2014.

MENDONÇA, L. D. Acompanhamento Terapêutico e clínica do cotidiano. 1a ed. São Paulo: Agente publicações, 2017.

MORAES, A. A. R. E. Winnicott e o Middle Group: a diferença que faz a diferença. Vol. 10. São Paulo: Natureza Humana (Revista de Filosofia e Psicanálise), 2008.

NOVINSKY, I. W. Edith Stein (1891 - 1942) em busca da verdade em tempos sombrios. Tese de Doutorado. Universidade de São Paulo, 2012.

OLIVEIRA, C.M; SAFRA, G. O lugar da família na clínica do Acompanhamento Terapêutico. Trabalho apresentado na 46 ${ }^{\mathrm{a}}$ Reunião Anual da Sociedade Brasileira de Psicologia. Fortaleza - Ceará, 2016.

OLIVEIRA, C. M; SAFRA, G. Acompañamiento Terapéutico y Familia: un encuentro entre generaciones y la importancia del gesto. Trabalho apresentado no XII Congreso Argentino de Acompañamiento Terapéutico. Mar Del Plata Argentina, 2016a.

PEIRCE, C. S. Semiótica. 3를 Edição. São Paulo: Editora Perspectiva, 2005.

POSSANI, T. A experiência de 'sentir com' (Einfühlung) no acompanhamento terapêutico: a clínica do Acontecimento. Dissertação de Mestrado. Instituto de Psicologia da Universidade de São Paulo, 2010.

PRADO, A.; SAFRA, G. Sobre o cotidiano como horizonte de revelação: diálogo entre Adélia Prado e Gilberto Safra. DVD, Conferência proferida em 15 de novembro de 2012. São Paulo: edições Sobórnost, 2012.

PROTA, Fernando Del Guerra. Estudos dos laços afetivos entre pais psicóticos e seus filhos: como seus filhos lidam com este "louco amor"?. 2010. Dissertação (Mestrado em Enfermagem Psiquiátrica) - Escola de Enfermagem de Ribeirão Preto, Universidade de São Paulo, Ribeirão Preto, 2010. Disponível em: 
$<$ http://www.teses.usp.br/teses/disponiveis/22/22131/tde-09032010-162738/>. Acesso em: 2016-06-11.

RANK, O. (1924). O Trauma do nascimento e seus significados para a Psicanálise. 1 ${ }^{\mathrm{a}}$ ed. São Paulo: Cienbook, 2016.

RODRIGUEZ, B.C.; GOMES, I. C. Novas formas de parentalidade: do modelo tradicional à homoparentalidade. Boletim de Psicologia, Vol LXII, № 136: 29-36, 2012.

ROSA, G. (1956). Grande Sertão: veredas. Rio de janeiro: Nova Fronteira, 2006.

ROUDINESCO, E. Família em desordem. Rio de janeiro: Jorge Zahar Editor, 2003.

SAFRA, G. A Entrevista inicial - Compreender e lidar com este momento decisivo. In: Psicanálise e Psicoterapias: teorias e técnicas. São Paulo: Instituto Sobornost, 2005.

SAFRA, G. A face estética do self. $3^{\mathrm{a}}$ ed. São Paulo: Ideias e Letras, 2005.

SAFRA, G. A po-ética na clínica contemporânea. $3^{\mathrm{a}}$ ed. São Paulo: Ideias e Letras, 2004.

SAFRA, G. Desvelando a memória do humano: o brincar, o narrar, o corpo, o sagrado, o silêncio. São Paulo: Edições Sobornost, 2006a.

SAFRA, G. Hermenêutica na situação clínica: o desvelar da singularidade pelo idioma pessoal. São Paulo: Edições Sobornost, 2006b.

SAFRA, G. Investigações em psicanálise na universidade. Psicologia USP, 171175, 2001.

SAFRA, G. Momentos Mutativos em Psicanálise: uma visão winnicottianna. São Paulo: Casa do Psicólogo, 1995. 
SAFRA, G. Placement: modelo clínico para o acompanhamento terapêutico. Edição Especial Temática: Acompanhamento Terapêutico. Ano X ( $\mathrm{n}$-18): p.13-20. São Paulo: Psychê (Revista de Psicanálise), 2006.

SAFRA, G. O Psicótico e sua inclusão no Humano. Palestra Proferida no I Simpósio Internacional sobre Manicômios Judiciários e Saúde. São Paulo: Instituto Sobornost, 2009.

SAFRA, G. Uma clínica não reducionista: contemplando todas as dimensões do ser humano. São Paulo: Instituto Sobórnost, 2014.

SANTOS, B. S. Um discurso sobre as ciências. Editora Cortez, 2010.

SANTOS, R. G. Textos, Texturas e Tessituras no Acompanhamento Terapêutico. Instituto A Casa. São Paulo: Hucitec, 2006.

SARAIVA, L. F (Org.); MANDELBAUM, B. (Org.). Família, contemporaneidade e conservadorismo. São Paulo: Benjamin Editorial, 2017.

TUFOLO, A. Os Eremitas Urbanos. Revista Atravessar de Acompanhamento Terapêutico. Vol. 4: São Paulo, 2014.

TURATO, E. R. Métodos qualitativos e quantitativos na área da saúde: definições, diferenças e seus objetos de pesquisa. Revista Saúde Pública, Vol. 39, no 3: São Paulo, 2005.

WINNICOTT, D. W. A criança e o seu mundo. 6” ed. Rio de Janeiro: LTC Editora, 1982.

WINNICOTT, D. W. (1965). A família e o desenvolvimento individual. $3^{\mathrm{a}}$ ed. São Paulo: Martins Fontes, 2005a.

WINNICOTT, D. W. (1958). Da Pediatria à Psicanálise: obras escolhidas. Rio de Janeiro: Imago, 2000.

WINNICOTT, D. W. (1989). Explorações Psicanalíticas. São Paulo: Artmed, 2007. 
WINNICOTT, D. W. Natureza Humana. Rio de Janeiro: Imago, 1990.

WINNICOTT, D. W. O Ambiente e os Processos de Maturação: estudos sobre a teoria do desenvolvimento emocional. Porto Alegre: Artes Médicas, 1983.

WINNICOTT, D. W. (1987). Privação e Delinquência. 4ª Ed. São Paulo: Martins Fontes, 2006.

WINNICOTT, D.W. (1989). Tudo começa em casa. 4ª Ed. São Paulo: Martins Fontes, 2005b.

ZIMERMANN, D. E. Vocabulário Contemporâneo de Psicanálise. Porto Alegre: ARTMED, 2001.

* Obra localizada na capa desta dissertação: Família (1925). Artista: Tarsila do Amaral, São Paulo. 